\title{
علاج قلق الموت بالقراءة: دراسة تجريبية على عينة من المسنين

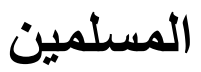

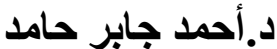

المدرس بقسم المكتبات و المعلوماتـ- مات

كلية الآداب- جامعة أسوان

مستخلص

تهدف الدر اسة إلى اقتر اح برنامج قر ائي يساهم في خفض مستوى قلق الموت عند المسنين

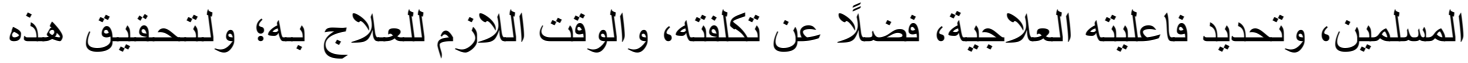
الأهداف اتبعت الدر اسة المنهج التجريبى من خلال تجربة قبلية بعدية، طُبِّقَ فيها البرنامج القر ائي

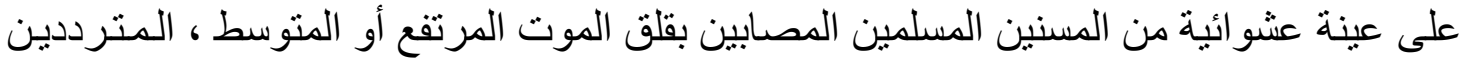

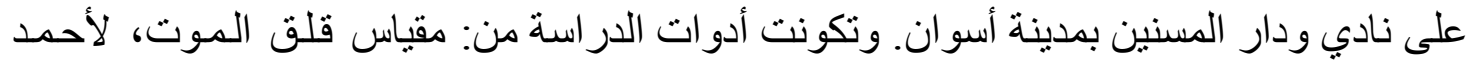

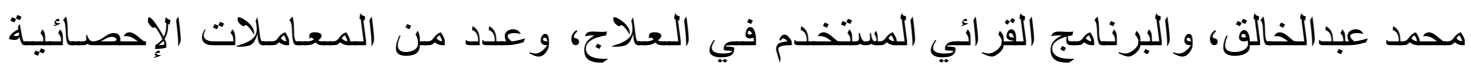
المناسبة لطبيعة الدر اسة.

\section{وتوصلت الدراسة إلى عدة نتائج، أهمها:}

فاعلية البرنامج المقترح للعلاج بالقر اعة في خفض مستوى قلق الموت لدى أفر اد المجموعة التجريبية؛ لوجود فروق ذات دلالة إحصائية عند مستوى (0.. •) بين درجات المجموعة التجريبية في التطبيقيْن: القبلي، والبعدي، لصالح البعدي، حيث إنخفض قيمة المتوسط الحسابي

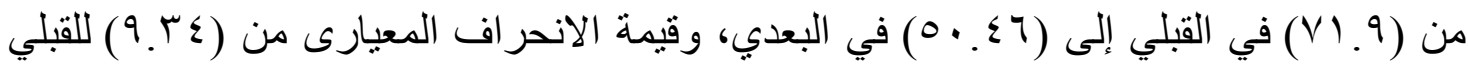

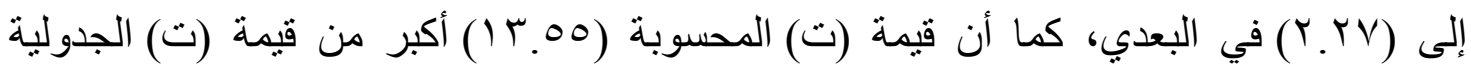

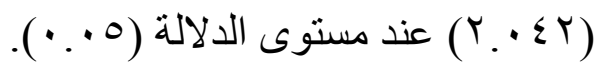

وتبين للار اسة أن الوقت اللازم للعلاج بالبرنامج القرائي المقترح (9ساعات)، وتكلفته 
(لاتتعدى · · 1 جنيه)، و أنهما أقل من مثليهما في طرق العلاج التقليدية. و أوصت الدر اسة بـ: صياغة بر امج قر اعة علاجية لمختلف الأمر اض النفسية و العضوية التي

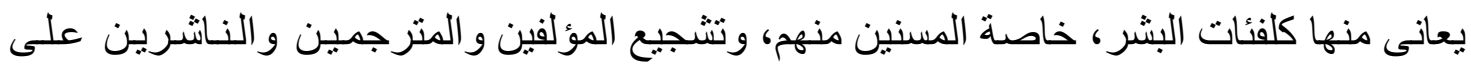

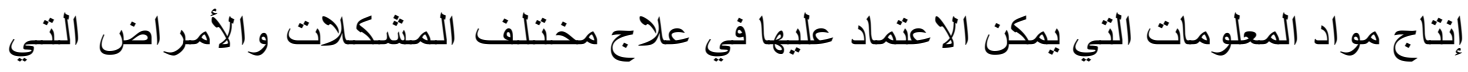
تصيب الإنسان، سواء كانت نفسية أو اجنماعية أو عضوية.

الكلمات المفتاحية:

المسنون، الثيخوخة، رعاية|لمسنين، العلاج بـالقراءة، الببليوثيرابى، العـلاج السلوكي المعرفي، قلق الموت، الاضطر ابات النفسية، الصحة النفسية.

- - تمهـي

القلق حالة نفسية غير سارة، تصبب مَن يشعر بها بخوفٍ أوتهديدٍ، مما لا بمكن تحديده بدقة،

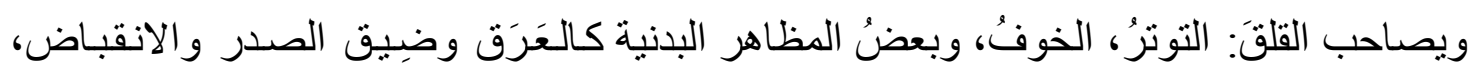

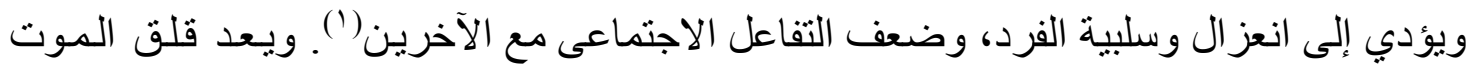

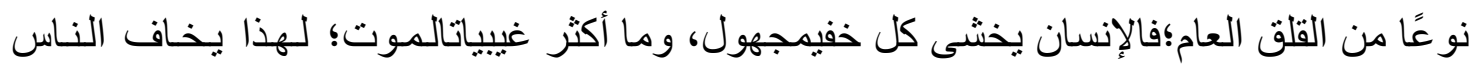

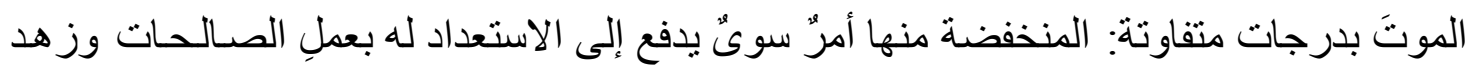

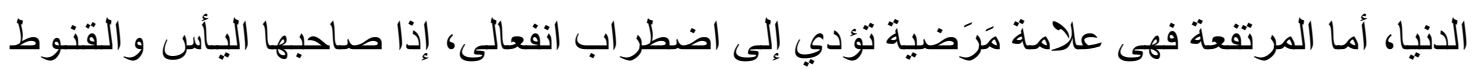
من رحمة الله.

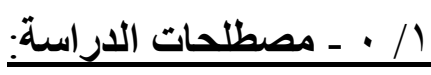

ـ قلق الموت Death Anxiety: هى حالة نفسية مُكَدِّرة،تسيطر على الفرد بأن الموتــ و مـا يتعلق

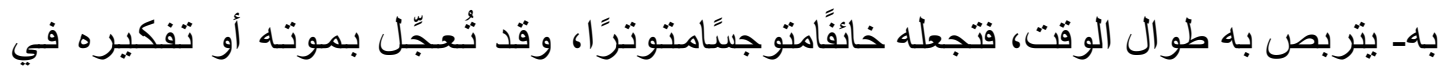

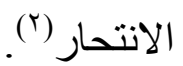

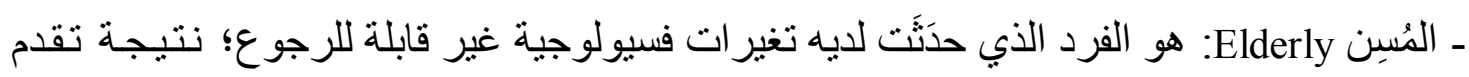

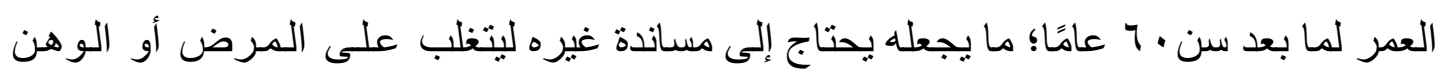

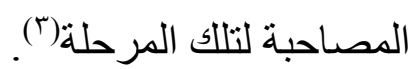

ـ العلاج بالقر اءة Bibliotherapy: هو "الاستعانـة بقر اءات دُختـارة لأغر اض العـلاج النفسي

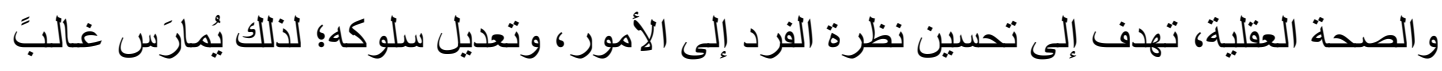

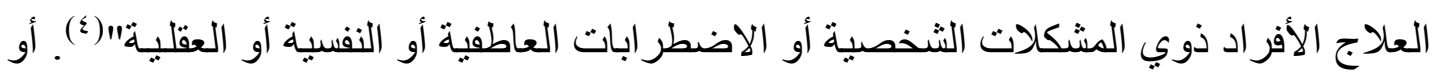

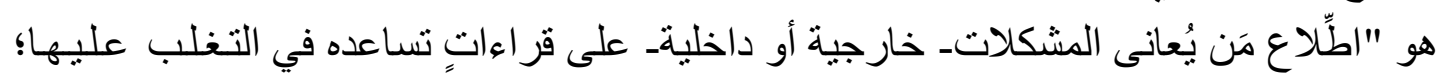
فهو علاج فكري يركز على الأفكار و المعتقدات والانفعالات؛ ليغير ها من سلبيـة إلى إيجابيـة داءية 


\section{بَنَّاءة ثُرَسِّخُ لحياةٍ سوية بدون مرض أو مشكلات"(ه).}

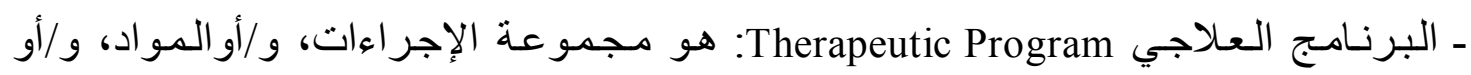

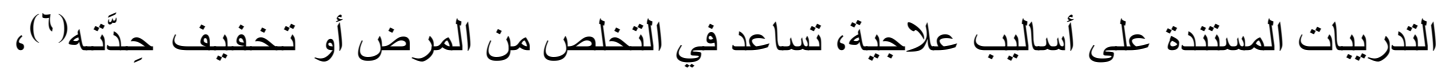

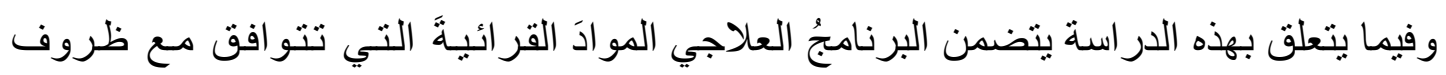

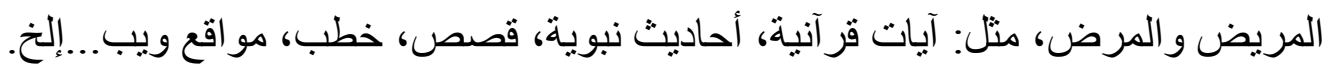
ـ المجمو عة العلاجية Valetudinarians/ Therapeutic Group: هى مجمو عة الأفر اد الذين يعانون

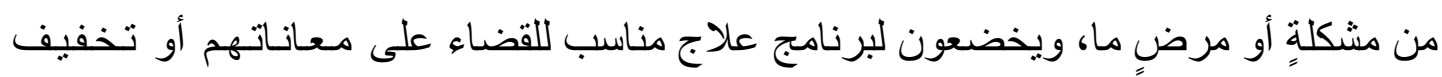

$$
\text { حدتها. }
$$

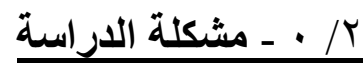

تتمثل مشكلة الدر اسة في عدة جو انب، هى:

أ - تتو عت و انتشرت الأمر اض النفسية في العصر الحديث، بعضها يمكن ملاحظته وبعضها

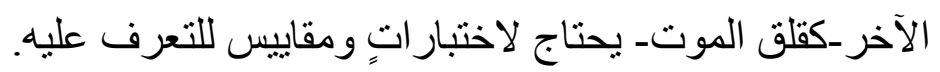

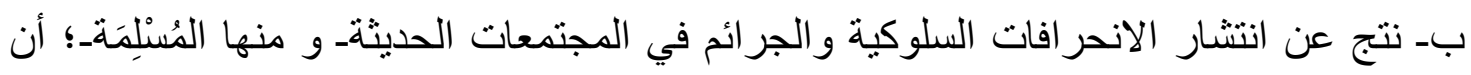
اتجه المهتمون إلى الدِين، مستغلين تقدير الفرد لهـ لتغذية الجانب الروحي؛ حتى يستطيع الفرد

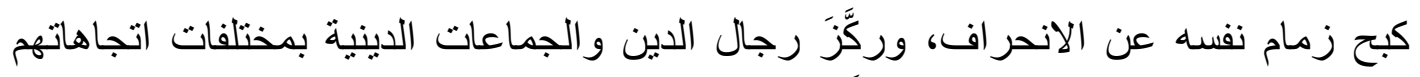

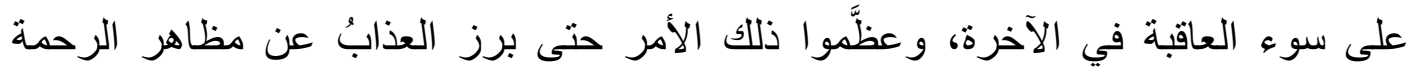

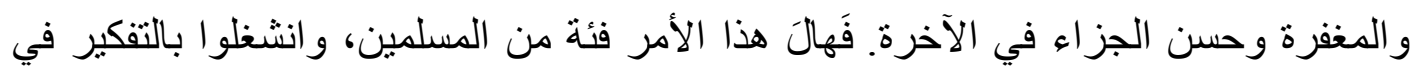

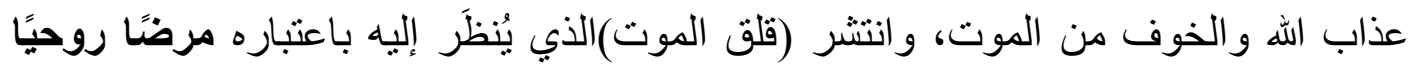
نفسيًا، وهذه القضية هى محور الاهتمام الرئيس في هذه الدر اسة.

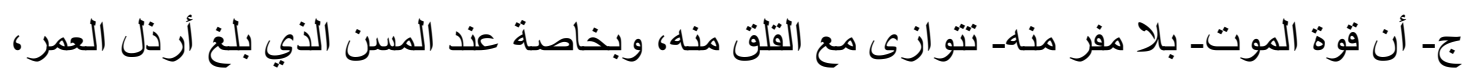

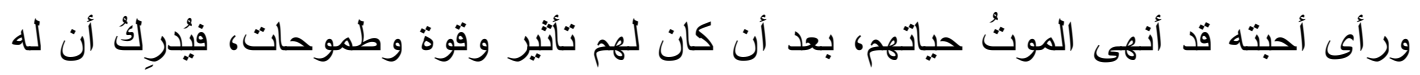

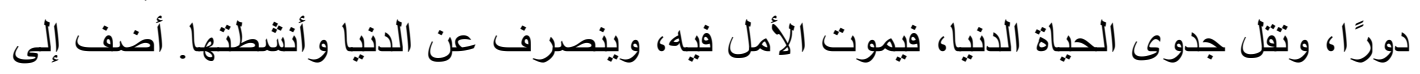

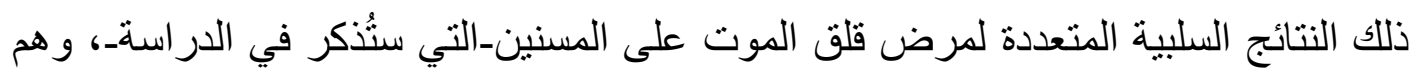

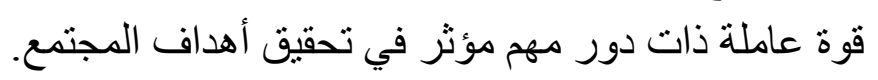

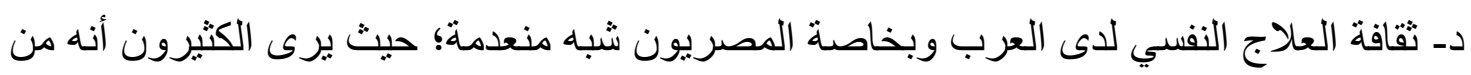

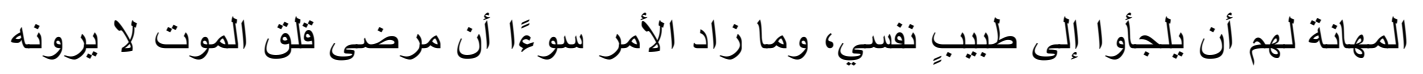

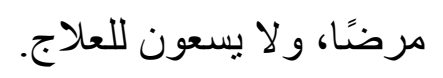

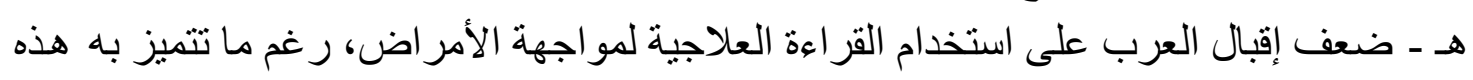

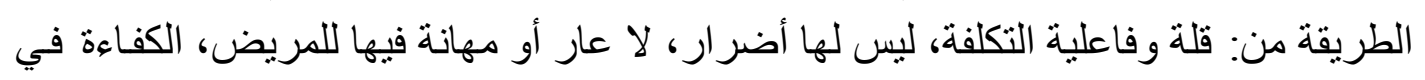




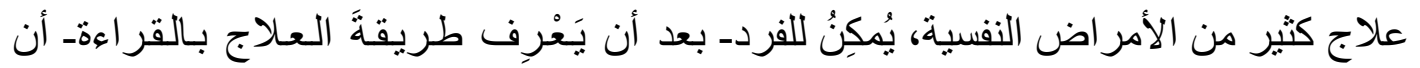

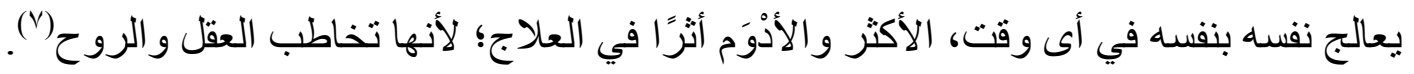

ب/ م · ماهرة الدراسة

ظهرت ظاهرة الدر اسة في عدةصور ، هى:

أـ يقهر الموتُ حياتَنا بطر ائق شتى: بإنذار أو بدون، في أى وقت ومكان؛ لذا يخشاه كل فرد

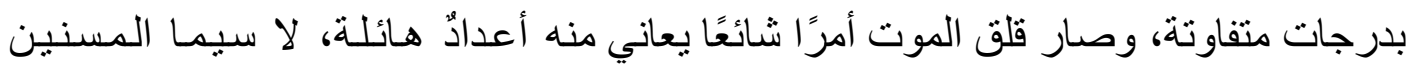
المسلمين.

بـ بَعَد القدرة على مواجهة متطلبات الحياة ومشكلاتهـا، يَحْدُث للمسن تخغيِرات بيولوجية

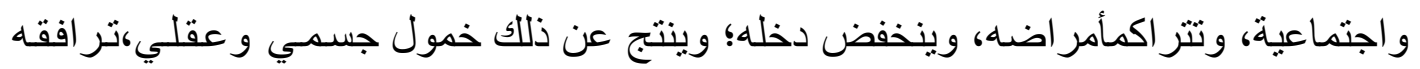

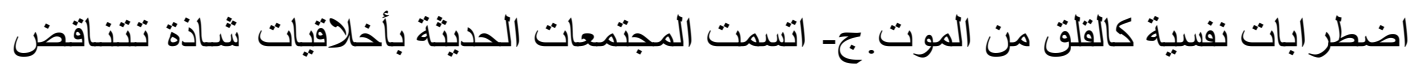

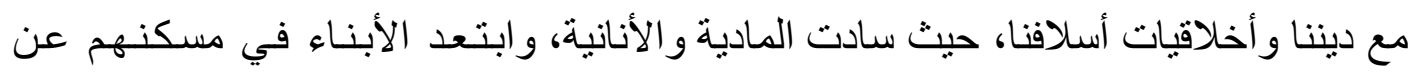

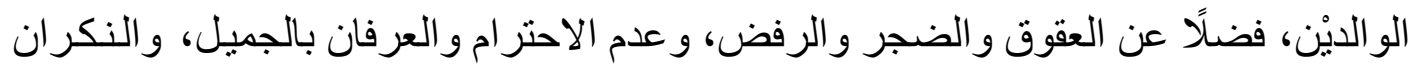
له، فأثَّرَ ذلك سلبًا على كثير من الجو انب النفسية للمسنين لا سيما القلق من الموت.

ع/ · ـ أهمية الار اسة ومبررات اختيارها

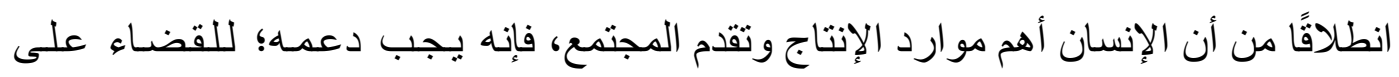

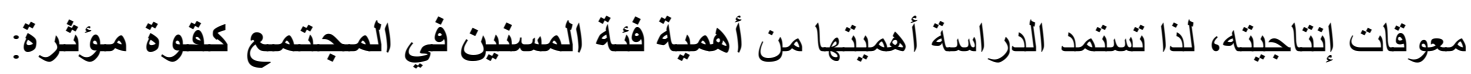

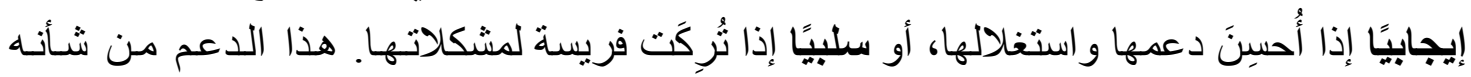

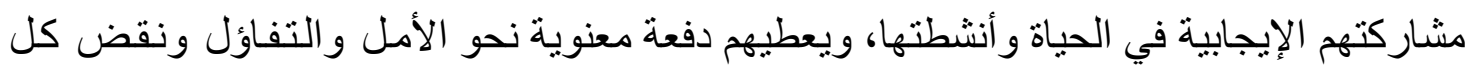

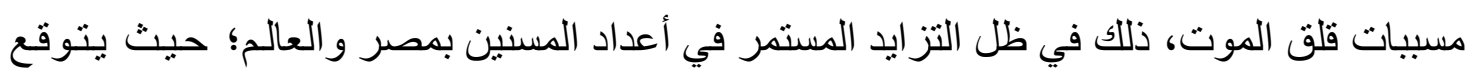

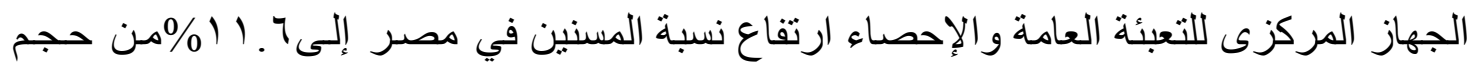

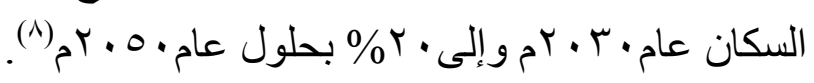

ـ تتسم الدر اسـة بأهمية تطبيقية علاجية لقلق الموت، اعتمادًا على نظرتيْن، هما: أن يستبدل المسن

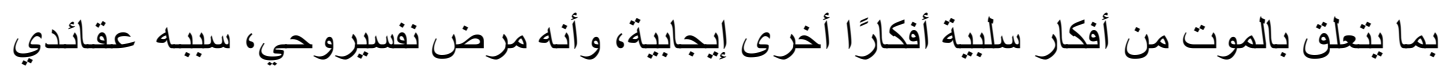

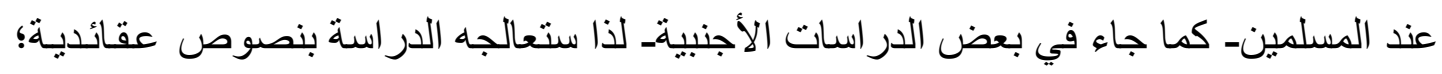

\section{لئلا يُقالإن الإسلام هو سبب لاستفحال هذا المرض.}

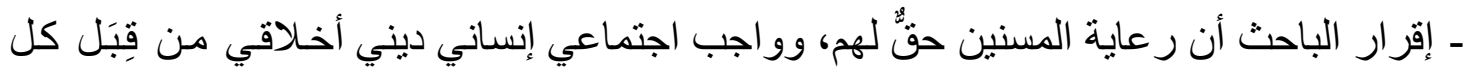

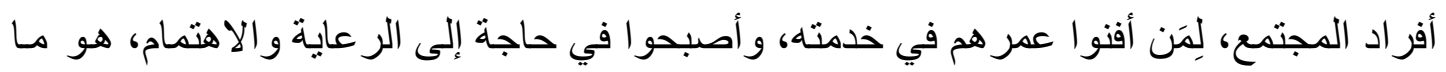

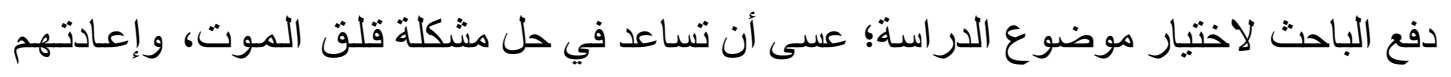


للمشاركة في بناء المجتمع بخبر اتهم الكثيرة المتر اكمة، وفي الاستقر ار النفسي لهم، وشعور هم بالحياة و الاستمتاع بها دون قلق حتى آخر لحظة لهم فئهاء.

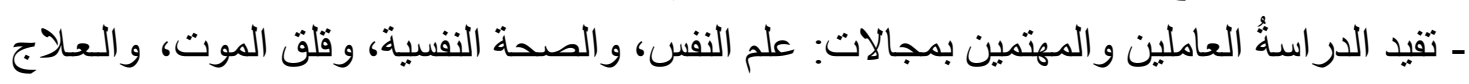

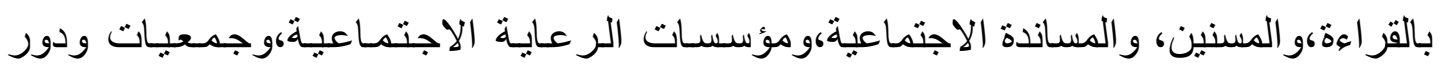

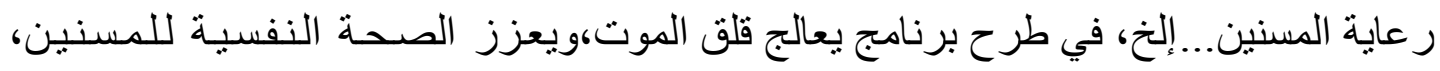

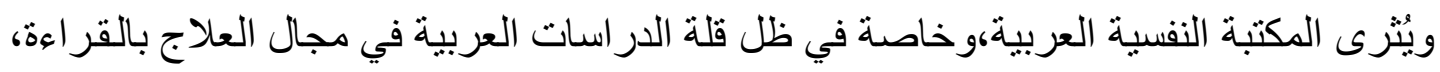

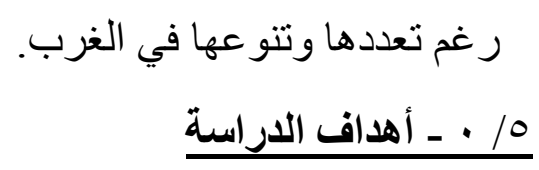

تهدف هذه الدر اسة إلى تحقيق الآتى:

ـ التعرف على طبيعة كل من: المسنين، ومرض قلق الموت. ـ اقتر اح برنامج قر ائي يمكن أن يسهم في علاج قلق الموت عند المسنين المسلمين. ـ تحديد فاعلية البرنامج المقترح فيخفض قلق الموت، بإجراء تجربة لعلاج عينة من المسنين المسلمين. ـ تحديد الوقت اللازم لعلاج المسنين المسلمين من قلق الموت، باستخدام البرنامج القرائي المقترح. ـ تحديد تكلفة علاج قلق الموت باستخدام البرنامج القرائي المقترح.  تسعى الدراسة إلى الإجابة على الأسئلة الآتية: ا ـ ما طبيعة كل من: المسنين، ومرض قلق الموت؟ r- ما التصور المقترح للبرنامج القرائي الذي سيُستَخدَم لخفض قلت الموت عند المسنين المسلمين؟ مالبور

r- ما مدى فاعلية البرنامج القرائي المقترح فيخفض قلق الموت عند المسنين المسلمين؟ مأج ــ ما مقدار الوقت اللازم لعلاج قلق الموت عند المسنين المسلمين بالبرنـامـ العلاجي القرائي

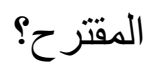
ــ ما حجم تكلفة علاج قلق الموت باستخدام البرنامج القرائي المقتر ح؟ 


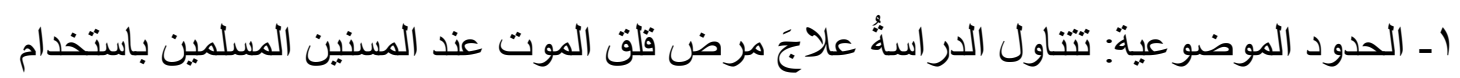
القر اهة.

rـ الحدود المكانية: طُبِقَتَ الدر اسة في نادي ودار المسنين بمدينة أسوان، على عينة من المسنين

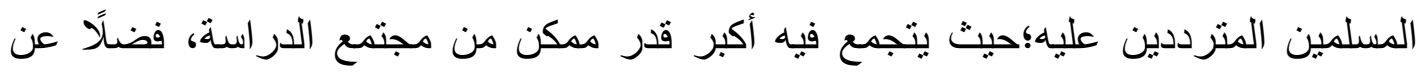

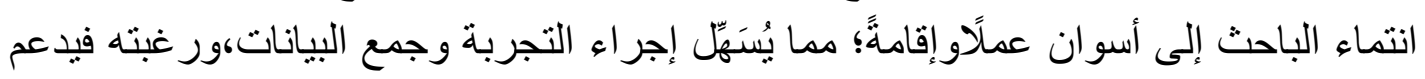

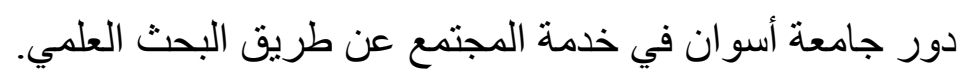

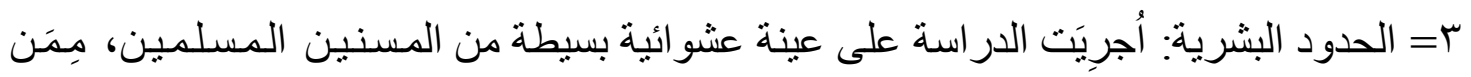
يعانون من قلق الموت بدرجة مرتفعة أو منوسطة.

/ / · ـ منهج الاراسة

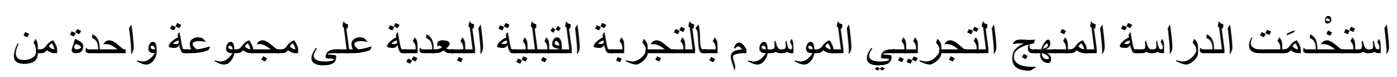

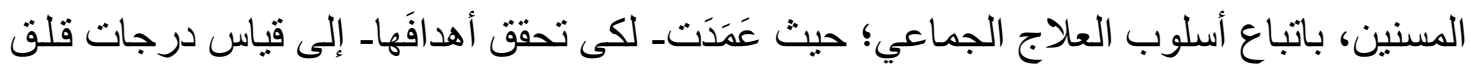

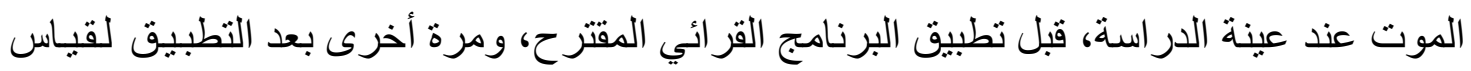

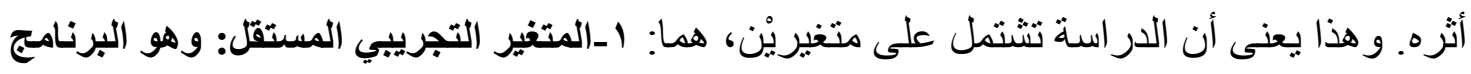

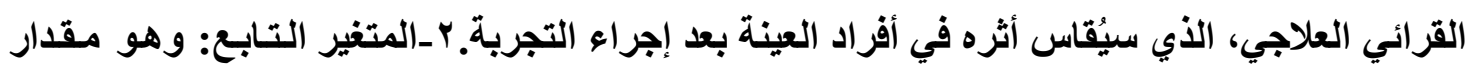

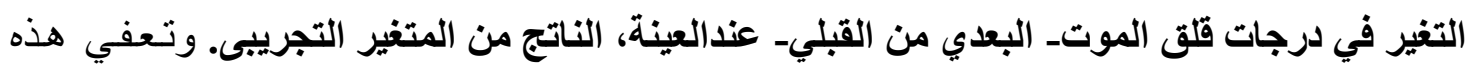

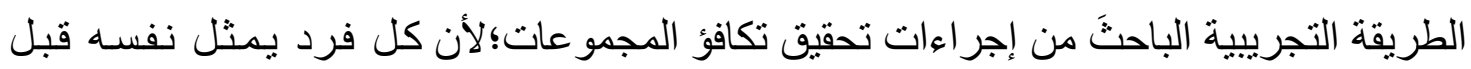

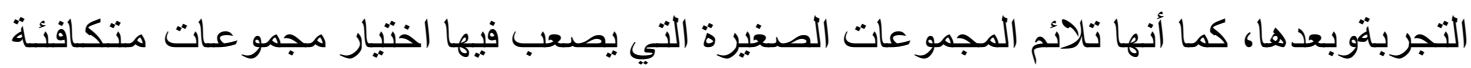

من بينها(9).

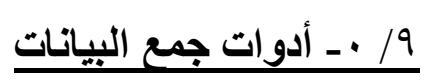

اعتمدت الدراسة لكي تجمع البيانات اللازمة لتحقيق أهدافها على عدة أدوات، هي:مقياس قلق القي

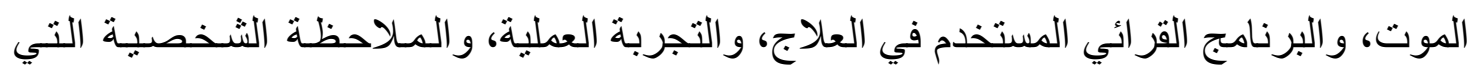

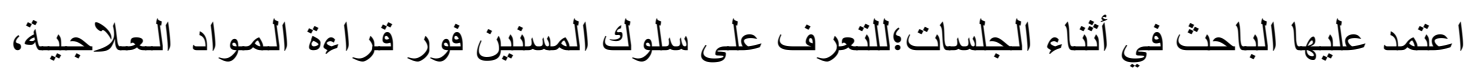

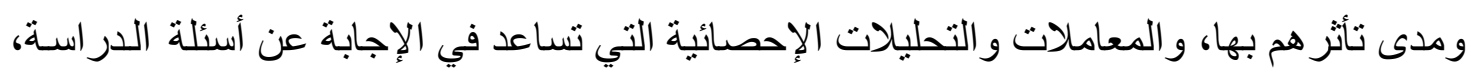

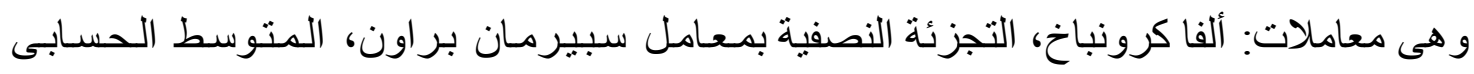

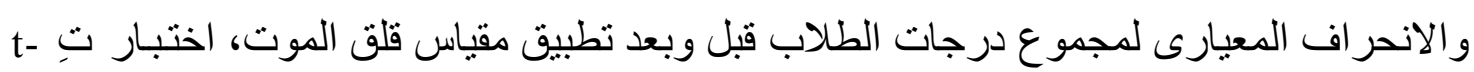

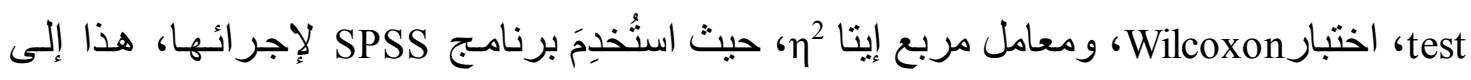




\section{جانب اختبار معامل كو هين الذي حُسببَ بمعادلة حسابية. \\ م / م مينة الدراسة}

يضم نادي ودار المسنين بأسوان بسه مسنًا، بين مقيم ومتردد عليـه، وقد أُجرِيَت الدر اسـة

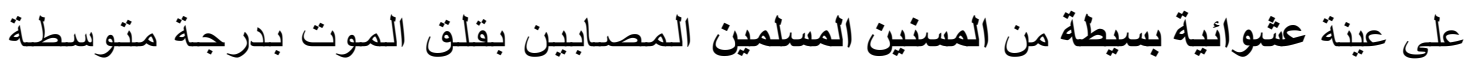

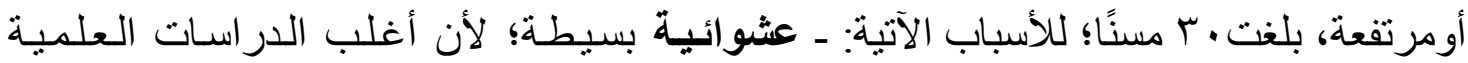

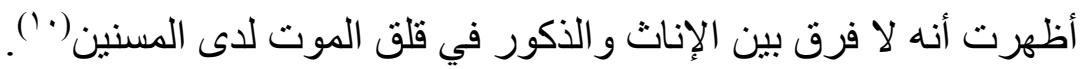
ـ أن المسن أكثر الناس قلقًا من الموت(')؛؛ بسبب: كبر سنه، وضعفه، و وعزه، ووفاة آخرين في نفس عمره أو أقل، و التقاعد...إلخ.

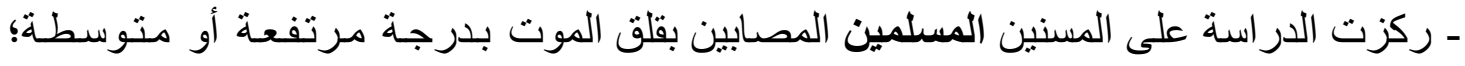

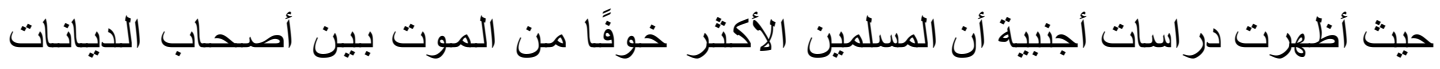

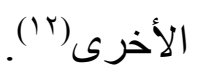



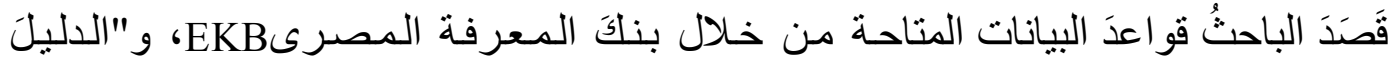

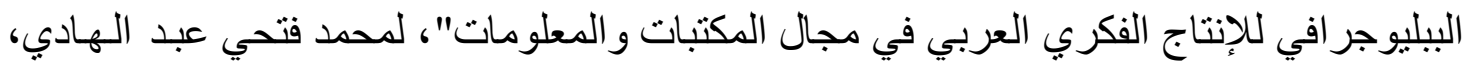

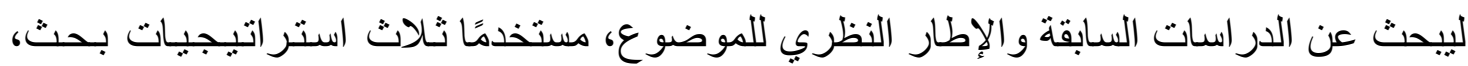

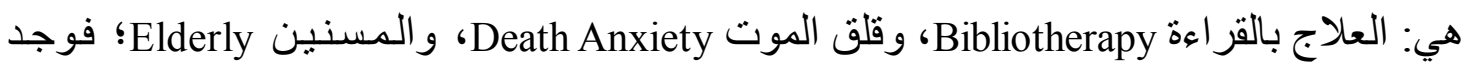
عدة در اسات مثيلة، يُمكِن عرض أقربها إلى الدر اسة الحالية في فئتنيْن كالآتى: وفئ أولَا ـ دراسات تناولت فاعلية العلاج بالقراءة لأمراضٍ أخرى غير قلق الموت، عند فئات أخرى غير المسنين:

1- Cutforth, Nancy Bohne (1980). The effect of group bibliotherapy in reducing the anxieties of children in grades one, two and three.Educat.D., North Illinois University. Available through EKBat:http://search.proquest.com/ docview/303057665?accountid=178282

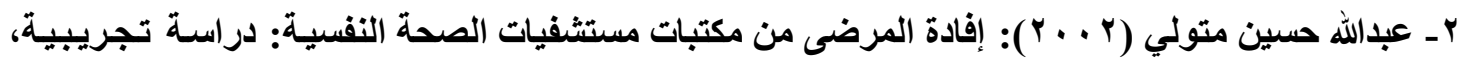

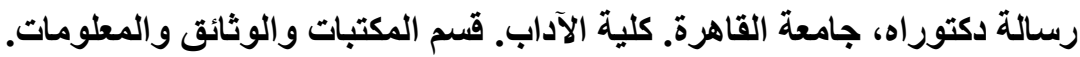

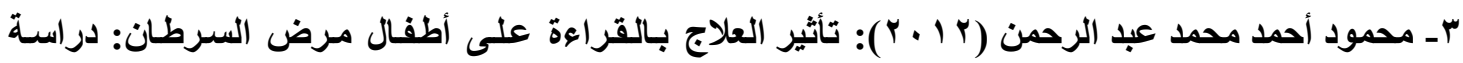

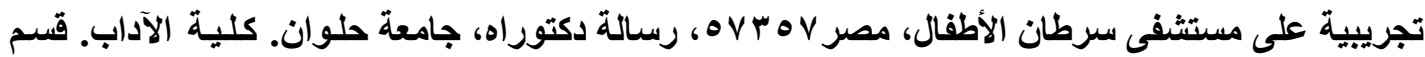




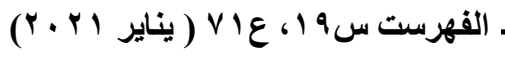
علاج قلق الموت بالقراعة: دراسة تجريبية على عينة من المسنين

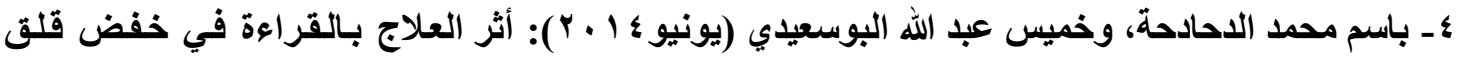

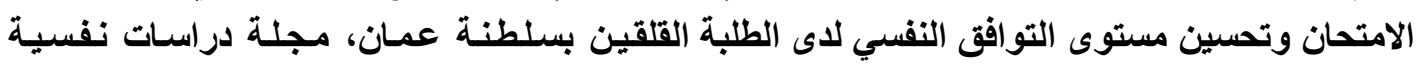

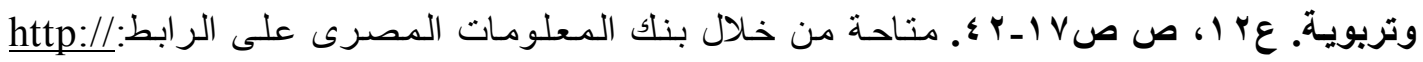
search.mandumah.com/Record/638860

هـ غاده عزت محمود أبو زويا (10 ب ب): علاج الاكتئاب بالقراعة: دراسة تجريبية على عينة من طلاب كلية

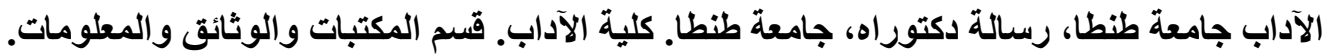
ثُانيًا:در اسات لفاعلية بر امج علاجية محدَّدة لقلق الموت، أو التصور ات عن الموت، وهى:

6- Templer, D. \& Ruff, C. \& Simlsom, K. (1974). Alleviation of high death anxiety with symptomatic treatment of depression. Psychological Reports. Vol. 35 (1), pp. 198-217.

7- McCalm, T. (1980). Death anxiety before and after death education: Negative results. Psychological Reports. Vol.46, pp. 494-515.

8- Trent, C. \& Glass, L. \& McGrr, A. (1981). The impact of a workshop on death and dying on death anxiety, lift satisfaction, and locus of control among middle -aged and older adults.Death education, Vol. 5(1), pp.157- 173.

9- Floyd, Mark Randal (1998). Cognitive therapy for depression: A comparison of individual psychotherapy and bibliotherapy for depressed older adults. Ph.D, The University of Alabama.

10- Todahl, Jeffery [et al] (win. 1998). Bibliotherapy and perceptions of death by young children. Journal of poetry therapy. 12 (no. 2), p. 95-107.

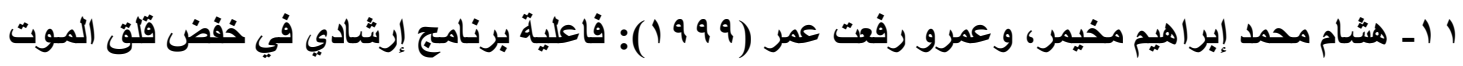

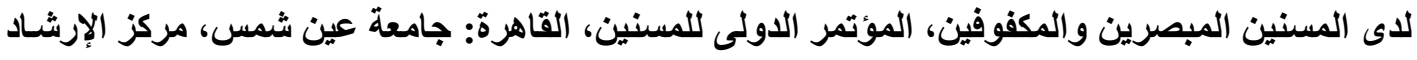

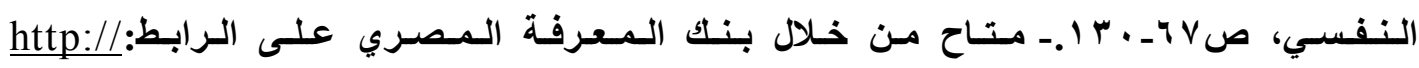
search.mandumah.com/Record/ $/ \mathrm{V} \tau \Lambda \mathrm{r}$

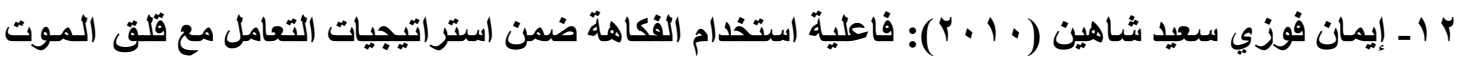

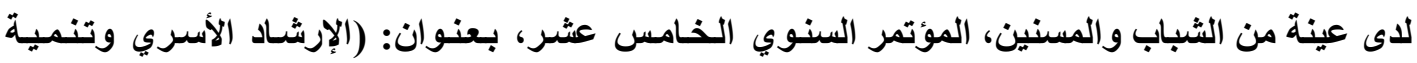

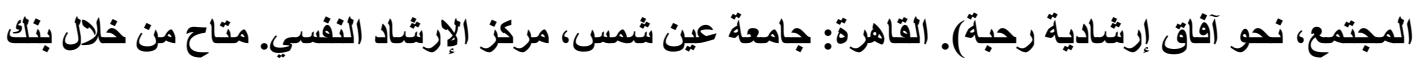

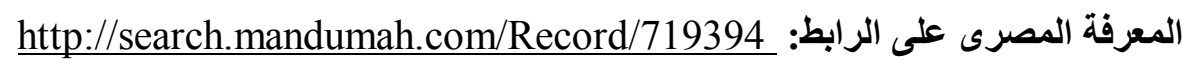

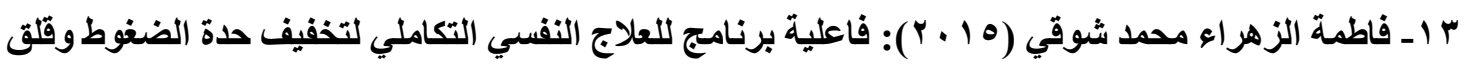

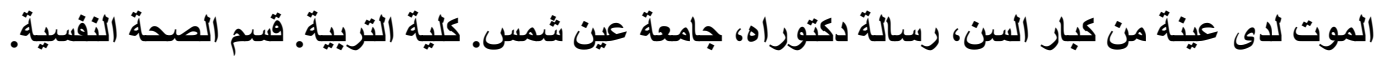


التعقيب على الاراسات السابقة

إن ما ييرر الدراسة الحالية هو اختلافها عن الدراسات السابقة من حيث:

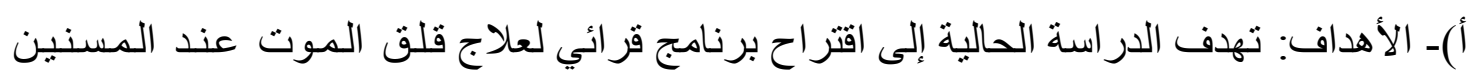

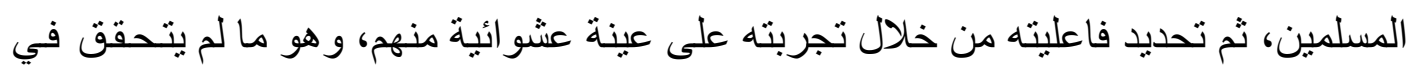

$$
\text { أي من الدراسات السابقة. }
$$

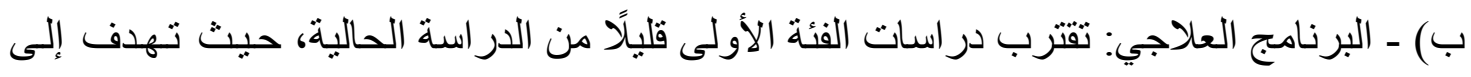

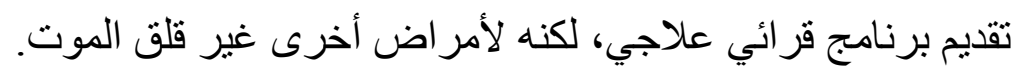

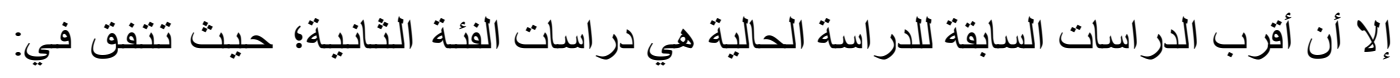

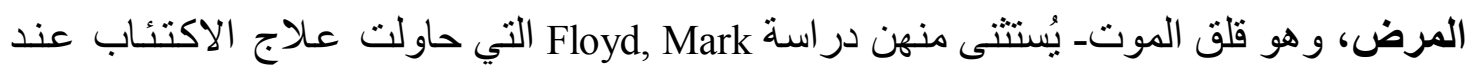

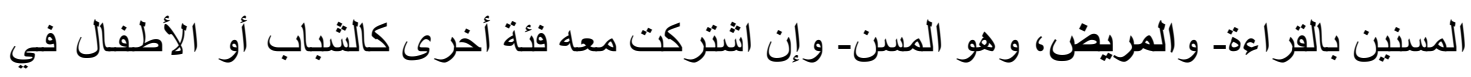

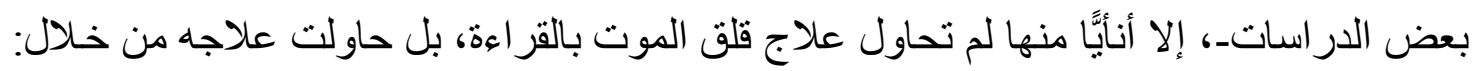

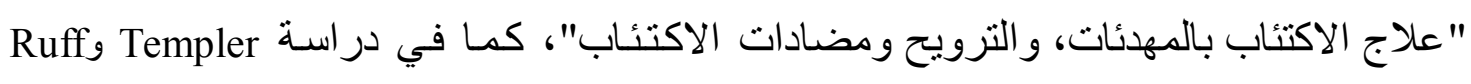

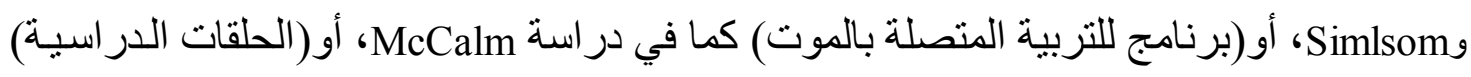

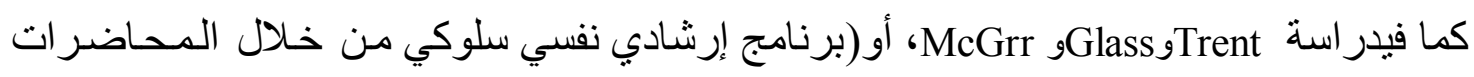

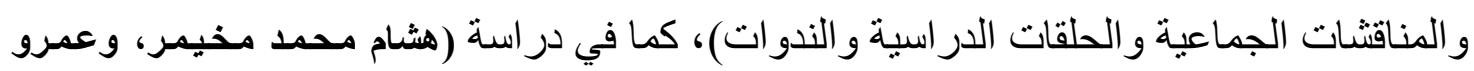

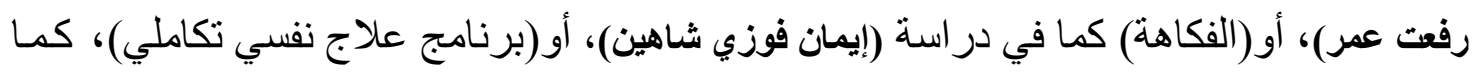

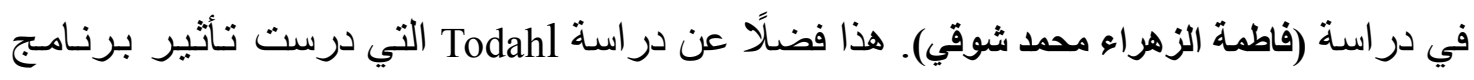

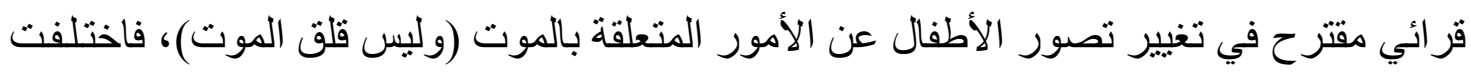
عن الدراسة الحالية في الهدف و الفئة المستهدفة.

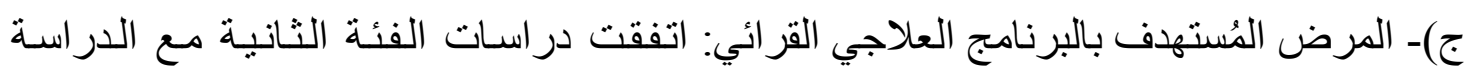

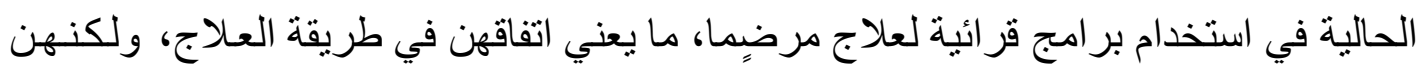

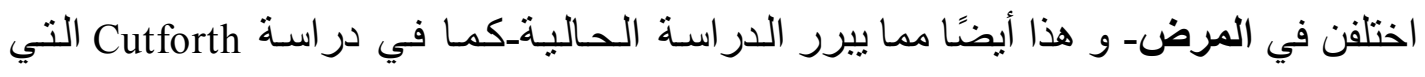

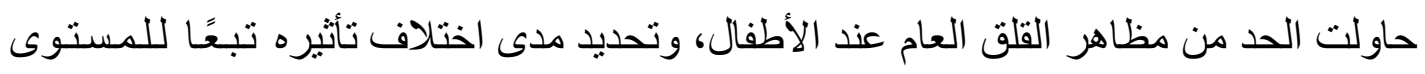

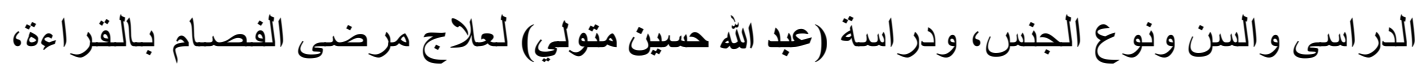

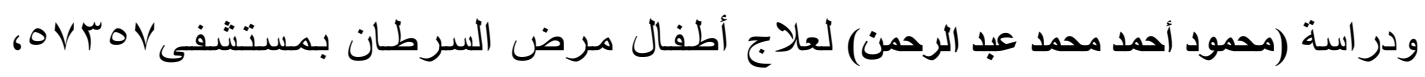

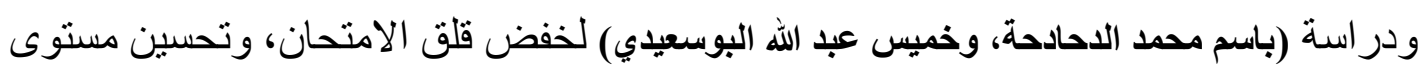

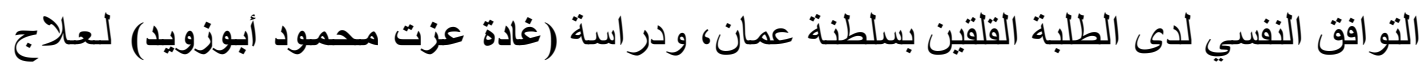

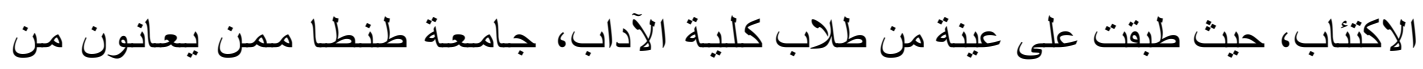
الاكتئاب المنوسط و الثديد. 
د)- مجتمع الدر اسة: شمل مجتمع الدراسة الحالية عينة عشوائية من المسنين المسلمين الذين

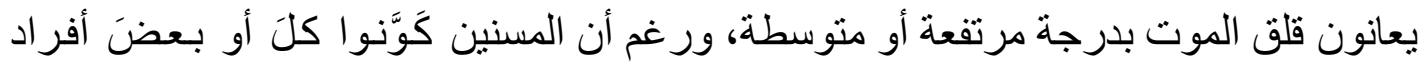

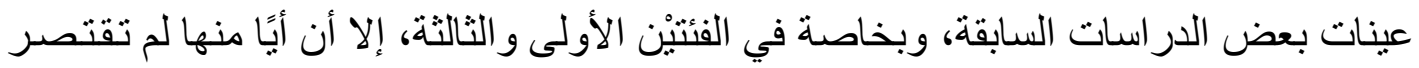
على المسنين المسلمين فقط.

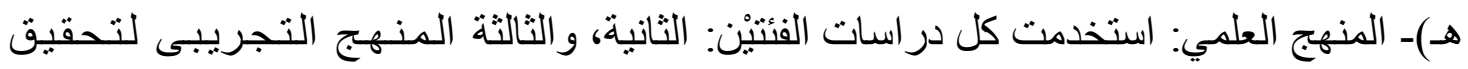
أهدافها، وإن اختلفت فيما بينهن في: أفر اد العينات وحجمها ونو عها وتقسيمها،و أدوات الدرات اســة ومقاييسها؛ على حسب ما فرضته أهداف كل در اسة منهن وموضو عها.

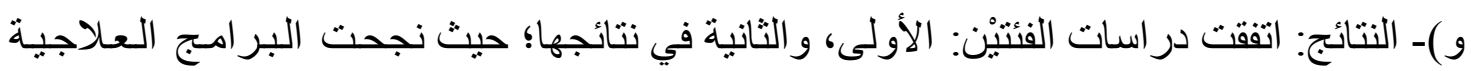
على اختلاف أنو اعها في علاج المرض المستهدف لكل در اسة بصورة كبيرة،باستنثناء در اسـة التي توصلت إلى عدم تأثير البرنامج العلاجي لها في أفراد العينة؛ لعدم كفايته.

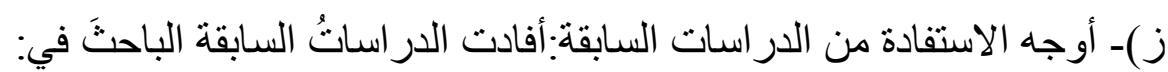
ا ـ تحديد أبعاد الدر اسة الحالية ومصطلحاتها ومتغير اتها(قلق الموت، و المسنين، و العلاج بالقز اءة). r- إثراء الإطار النظري، وتفسير نتائج الدراسة الحالية. rـ فهم أسباب ظهور قلق الموت عند الناس عمومًا، و المسنين المسلمين بصفة خاصة. عـ التعرف على مشكلات المسنين وحاجاتهم، وما يتعرضون له من ضغوطات و أمر اض. هـ تتبع خطو ات و إجر اءات تتفيذ الجانب التجريبى للار اسة الحالية، وتحليل نتائجها.

\section{أولًَا- الاراسة النظرية}

1/1 - المسنون

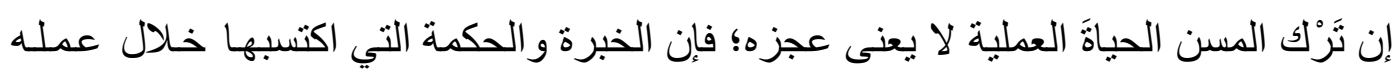

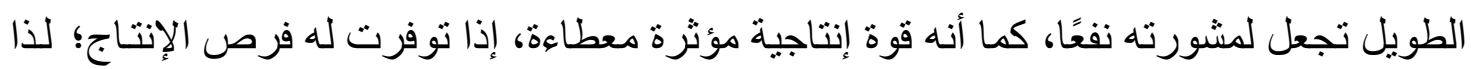

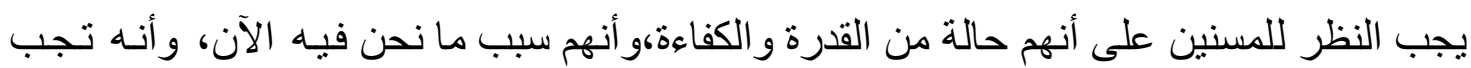

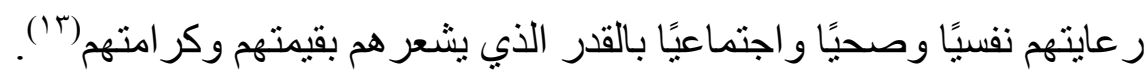
1/1/1/1 - حاجات المسنين: يحتاج المسنون إلى الآتى: أـ فهم طبيعة مرحلة المسنين، و التغيرات التي تؤثر في قدرتهم العقلية والجسمية التي تؤدي إلى دي

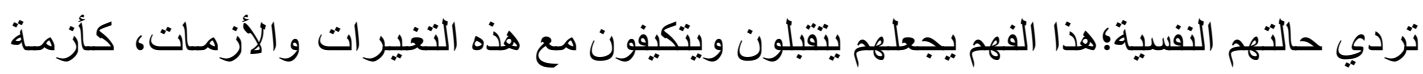

التقاعد أو وفاة عزيز عليهم(ء) (). 
بـالاحتياجات المادية و النفسية: إن توفير الحـاجات المـاديـة، كالمسكن و الملبس و المـأكل،

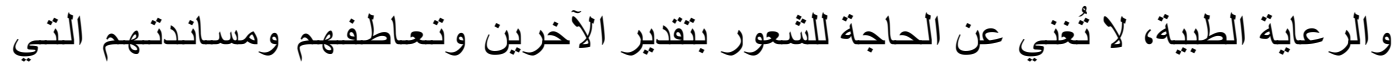

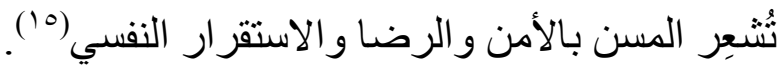
ج- الاحتياجات الاجتماعية،مثل: تكوين علاقات طيبة مع أفر اد المجتمع،الاعتر افبه عضوًا نـافعًا

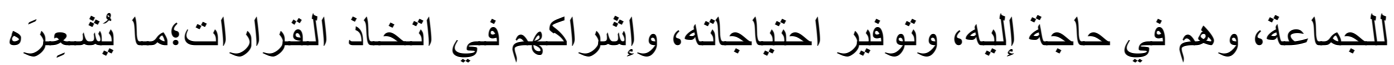

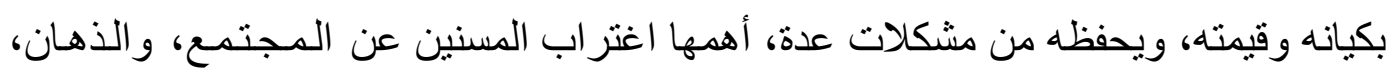
و العودة للماضى.

وقد تعددت احتياجات المسنين نتيجة لكثرة ما يعانون من مشكلات(1'(): صحية، واجتمـاعية، و الوحدة و انشغال الأبناء عنهم، ونفسية، وعلية وعاطفية، و اقتصادية.... إلخ.

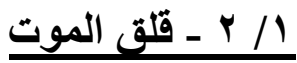

اهتم العلم الحديث بالموت؛لأهميتهه وتأتثيره في الإنسـان، فاستُحدِثَ علم دراسـة الموت

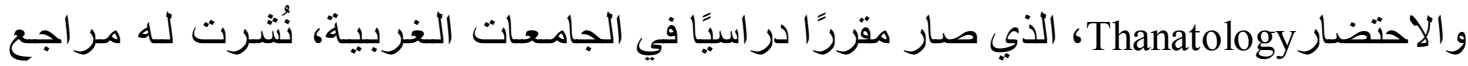

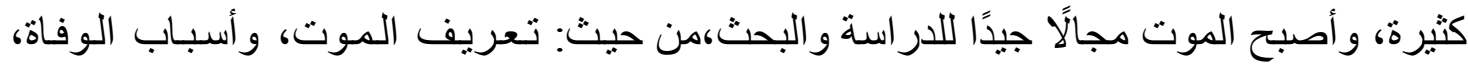

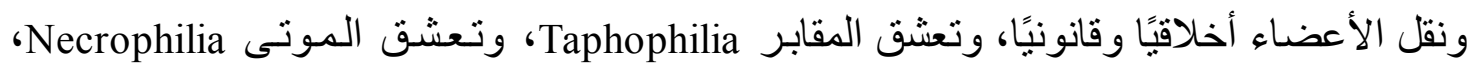

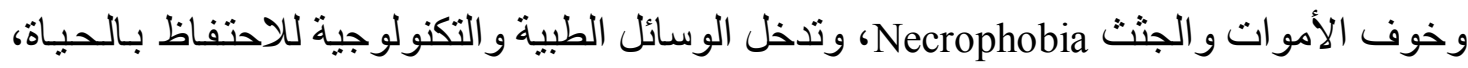

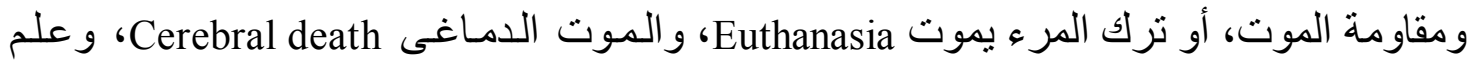

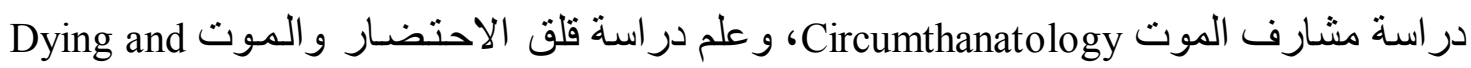

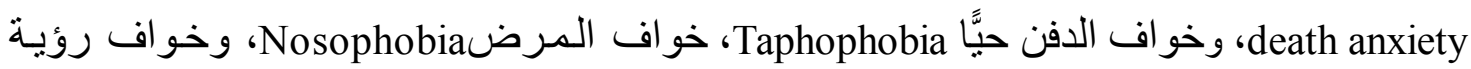
الدم Haematophobia.... إلخ ('). كما اهتمت كل الديانات بقضيتىّ: الموت، و الحياة، فَنَفَت الخلود، و أكدت الموت وفجأتـه؛فكان

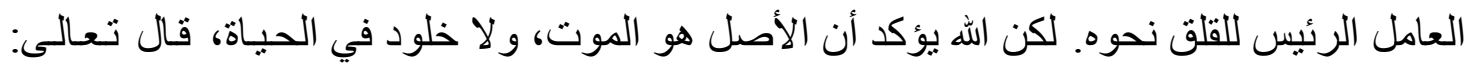

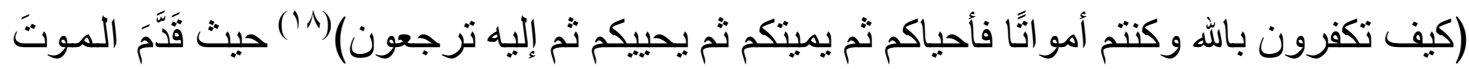

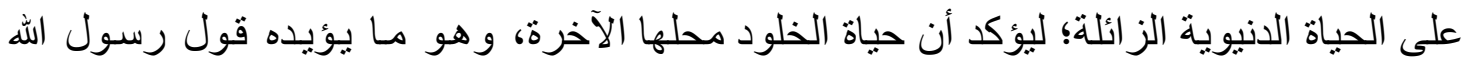
صلى الله عليه وسلم: \} الناس نيام فإذا ماتو ا انتبهو أج ، و غير ذللك من الآيات القرآنيـة و الأحساديث

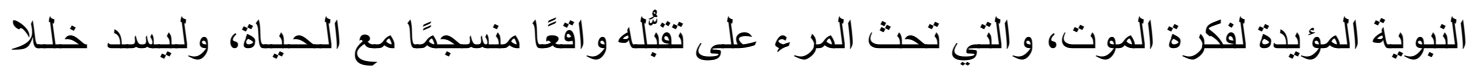

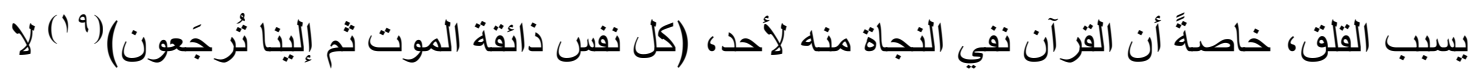

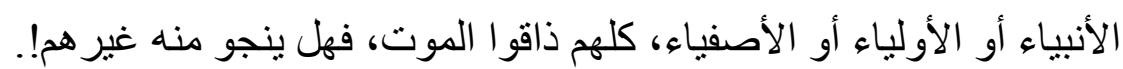
لذا يحرك الخوف من الموت سلوكيات كثيرة للإنسان بشكل مباشر أو غير مباشر ؛ فاهتم بـه 
علماء كُثر:تقول كلاين Klein: "إن قلق الموت هو أساس كل قلق"، ويعتقد بعض علمـاء التحلبل

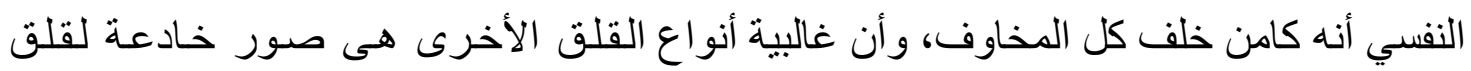

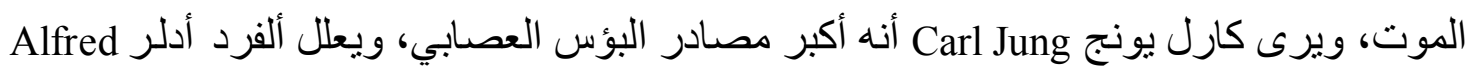
Adler

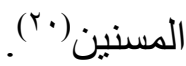

هذا وقد أسهبت مر اجع علم النفس في تناول النظريات المفسرة لقلق الموت، وتضيق الدر اسـة

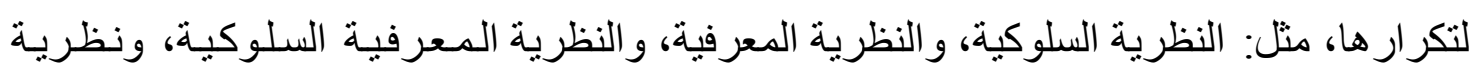
العاملَيْن.

/ / / ا ـ أعراض قلق الموت(Y'): تظهر على المصاب بقلق الموت عدة أعر اض، يُمكِن تصنيفها كالآتى:

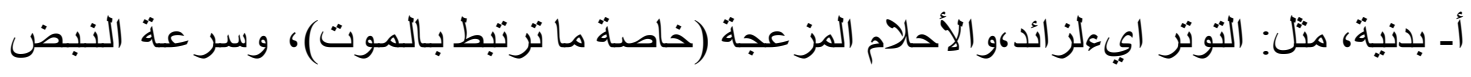

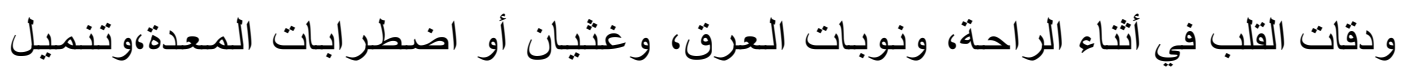
الأطر اف، ونوبات الدوخة و الإغماء.

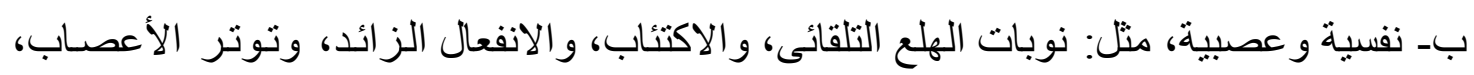

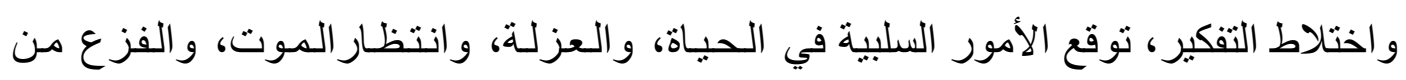
ذكر الموت، و اضطر ابات النومو اليقظة، الاختلاج.

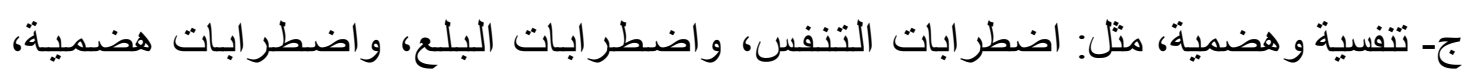
و إمساك، وقيء.

دـ أعر اض عامة، مثل: تعب عام أو كلي، وجفاف الجسم، وفقدان الثهية، واضطر ابات بولية. / / / ـ ـ درجات قلق الموت: يظهر قلق الموت في ثلاث درجات، هى: - بسيطة: حيث يظهر على المريض بعض من الأعر اض السابقة. ـ شديدة أو مزمنة: تظهر فيه مجموعة كبيرة من الأعر اض السابقة،وقد يصل الأمر إلى محساولة الانتحار. ـ متوسطة: يقع بين البسيط و الثديد.

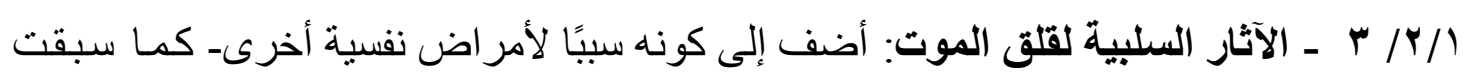

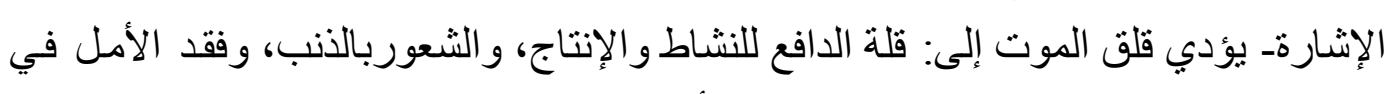

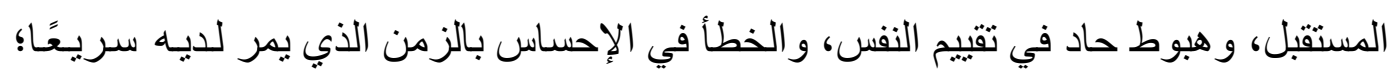


لخوفه من اقتر اب لحظة الموت، و افتقار المبادرة، ومحاولة الانتحار في الحالات المتقدمـة، و الهز ال بسبب قلة النوم وضعف الثهية، وز هد كل شئ في الحياة، و عدم الثعور بالمتعة. / / / ع ـ طر ائق علاج قلق الموت: يُستخدَم لعلاج قلق الموت ما يُستَخدم للقلق العام؛ لأنه نوع منه، وهي (r) (r)

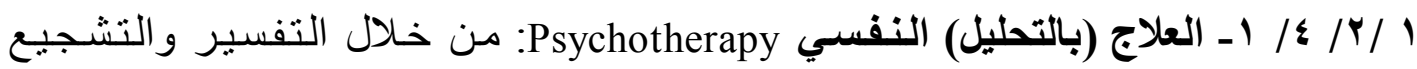
و التوجيه و الاستماع إلى صر اعات المريض، إلا أنه يتطلب وقتًَا وجهدًا ومالًا، ويُفضَّلَ ألا

$$
\text { يستخدم إلا مع الحالات الثديدة المزمنة. }
$$

ا / / \& / ץ ـ العلاج البيئي والاجتماعي Socio-environmental Therapy: عن طريـق إبعـاد

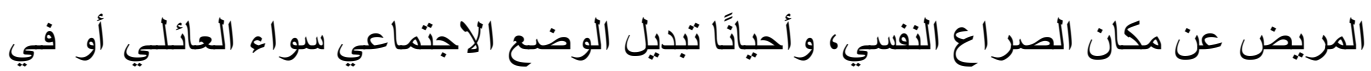

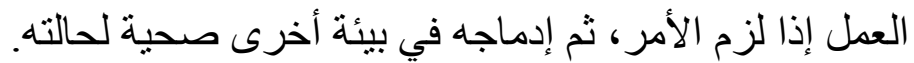

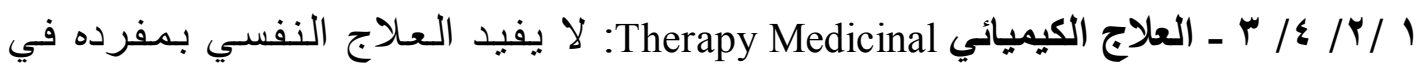
الحالات المزمنة، بل في البداية يتناول المريض أدوية مضادة للقلق Antianxiety drugs منثل: أـ المهئات المنومة Sedative-Hypnotic التي يعيبها تناقص مفعولهها التدريجي، وتؤدي للإدمان. وتضم هذه المجموعة: الباربتيورات Barbeturat، الجلسرول Glycerol

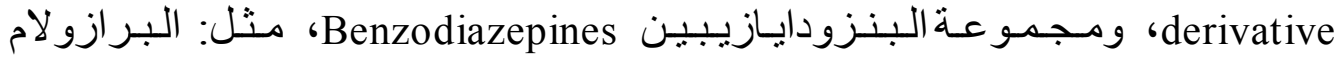
Alprazolam ولورازيبام Lorazepam، و الكلوديـازيا بوكسايد Chlodiazepoxide، وليبريوم Librium، وفاليوم Valium. بـ المهدئات المؤثرة على الجهاز العصبي المستقل Sedative autonomic التي تنغلب على تصى مشكلات المجمو عة السابقة، ولكنها تؤدي إلى توتر العضـلات، وتؤثر على الجهاز

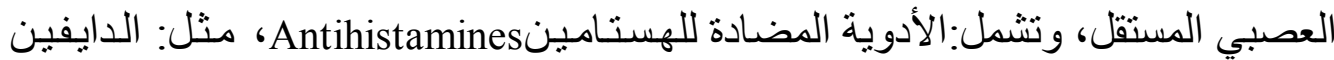
هايدر امين Diphenhydramine، أو بنـادريل Benadryl، والأدويـة المضـادة للذهـان

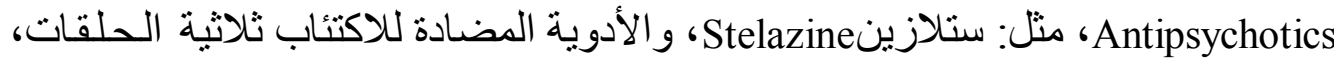

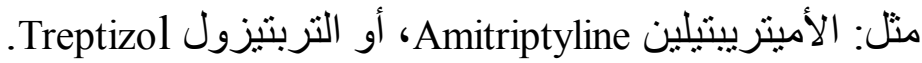
و عمومًا تتسم الأدوية المضادة للقلق بتأثير ات جانبية، منها: مفعولها المهدئ القوي، ونقص كص التركيز، مما يجعل بعض الأنشطة خطرة كقيادة السيار ات، فضلًَ عن التعود و الإدمـان، خـاصـة

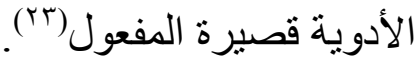




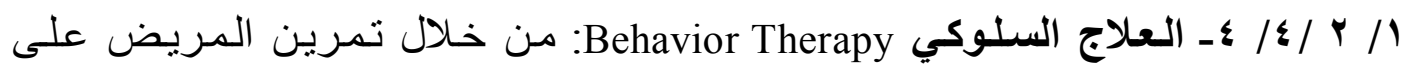

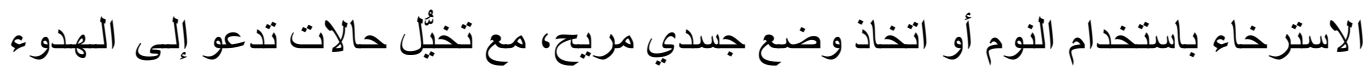

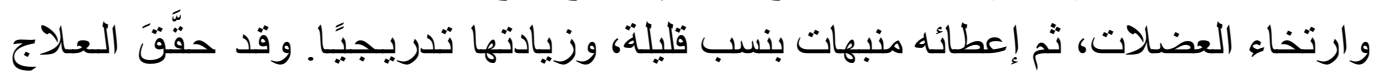
السلوكي أفضل نسب الثفاء بين طرق العلاج السابقة.

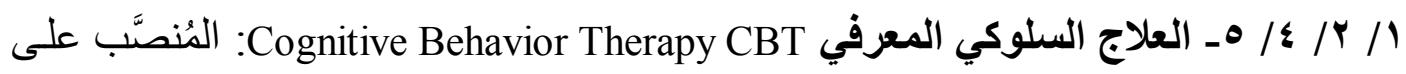

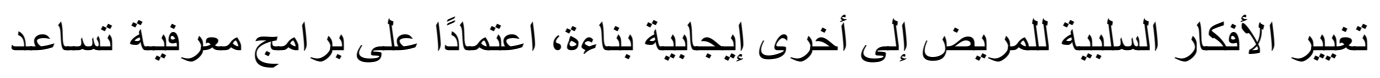

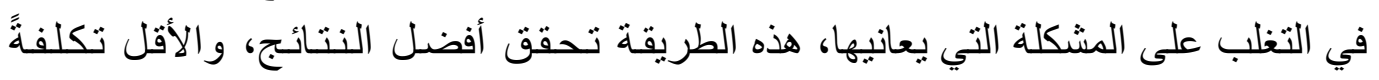

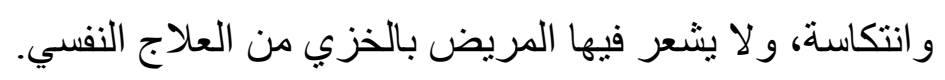

آ ـ ـ العلاج بالقراءة

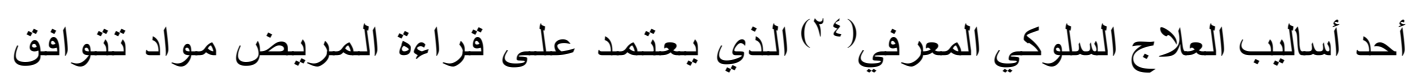

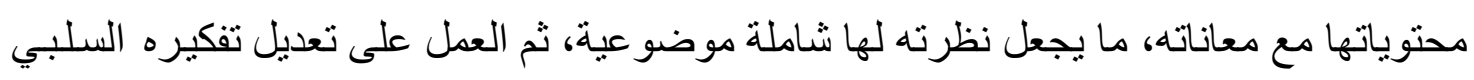

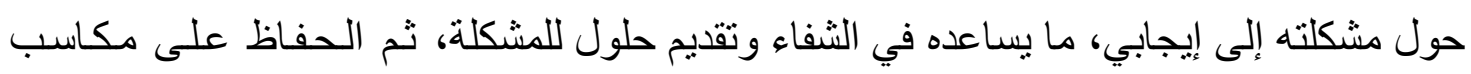

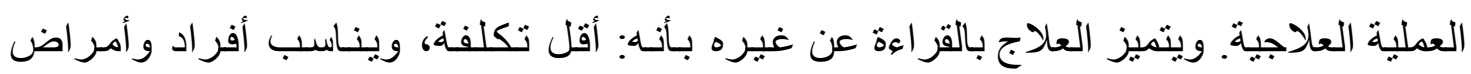

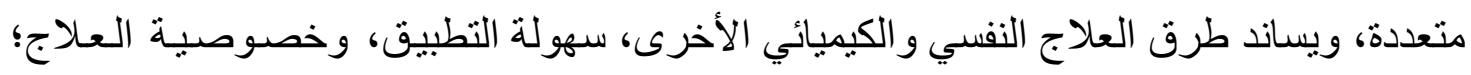

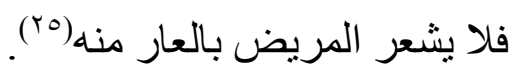

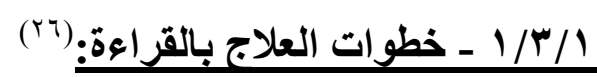

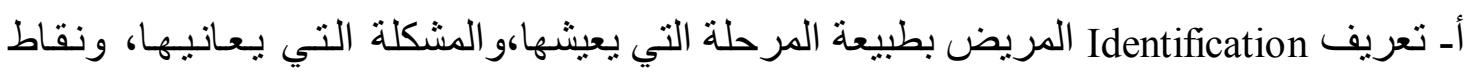

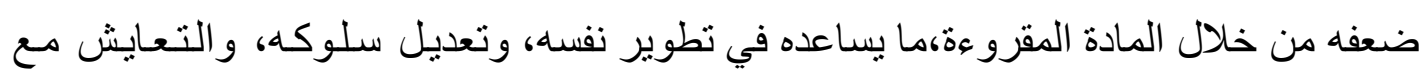
نفساه و غيره.

بـ التعبير عن مشاعره وتوتراته النفسية أو المشكلة، هو ما يُعرَف بالتنفيس Catharsis الذي يَتبَع التعريف.

ج- تحقيق رؤية جديدة للتغلب على المشكلة أو المرض،و هو ما يُعرَف بالتبصير Insight. 


\section{ثاتيًا إجراعات الدراسة التجريبية}

مرت الدر اسة التجريبية بالخطو ات الإجر ائية الآتية:

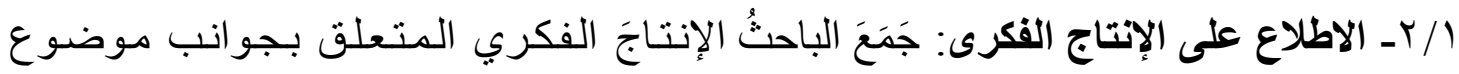

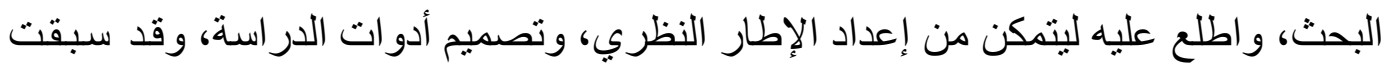
الإشارة إلى استر اتيجيات البحث المستخدمة لذلك،في صند إعدر الحديث عن الدر اسات السابقة.

r/r ـ اختيار مقياس قلق الموث DeathAnxiety Scale: اتجه الباحث نحو اختيار أحد المقاييس

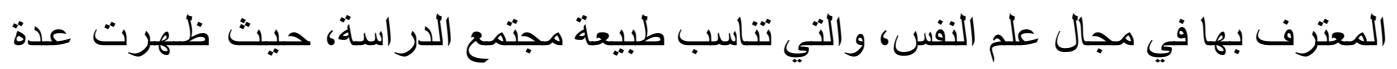
مقاييسأجنبية، كمقبـاس كوليتـ ليستر Colette-Leicester، بويـار Poier،دونـالد

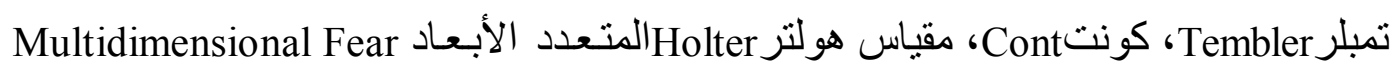
of Death Scale

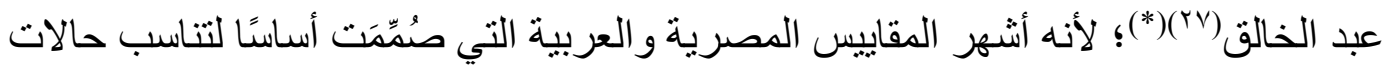

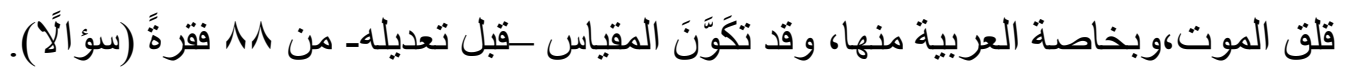
ويُسَجِّل المفحوصن قبل إجابة المقياس: اسمَه، وجنسَه، وسنَه، وحالته الاجتمـاعيـة، ومستو اه

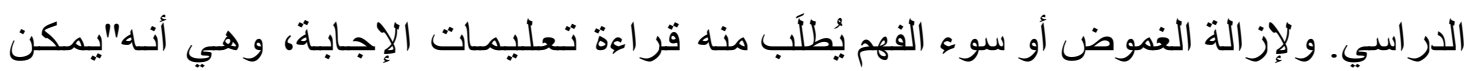

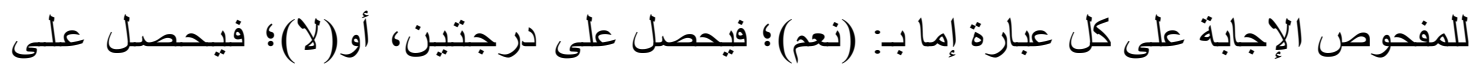

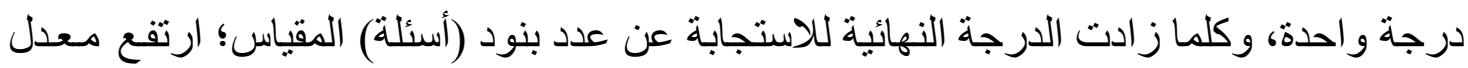

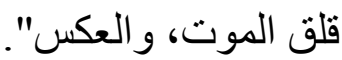

\section{r/ r ـ التحقق من صدق و ثبات مقياس قلق الموت:}

أُجرِيَت على المقياس المُخْتار عدة در اساتٍ أكدت صدقه (الظاهري والتـلازمي لـه)، وثباتهـ

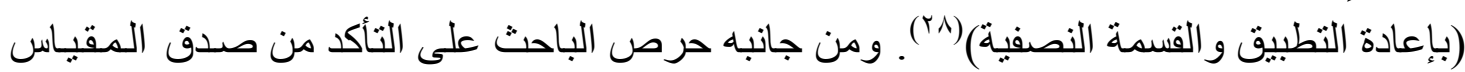
وثباته لأغر اض الدأسة الفة الحالية من خلال الإجر اءات الآتية:

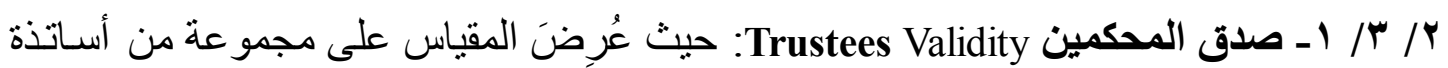

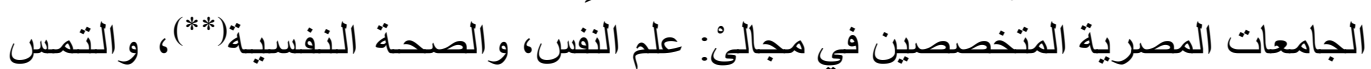

$$
\text { الباحث منهم إبداء آر ائهم إز اءعاء: }
$$

ا ـ الصدق الظاهرى للمقياس؛ للتأكد من: وضوح معاني الأسئلة، ودقة كلمـاتها، وسـهولة

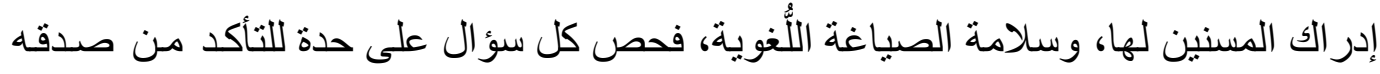
في قياس قلق الموت، و إمكانية إضافة أية أسئلة جديدة تزيد من كفاءتها. 


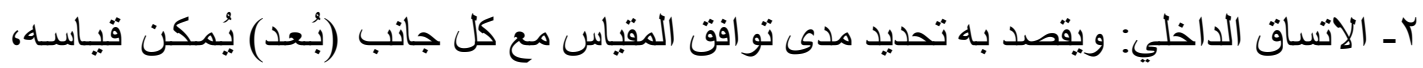

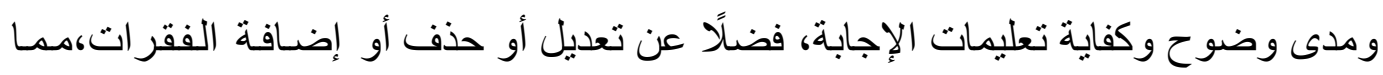
يزيد كفاءته.

وقد أُجريَتِ بعض التعديلات على الأسئلة،شملت: اختصار عددها إلى ما يزيد عن النصف

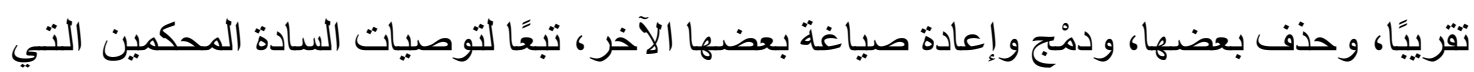

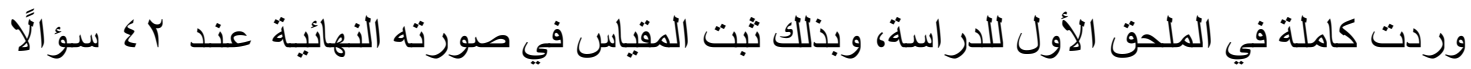
فقط تقيس مظاهر و أسباب قلق الموت.

Stability قياس ثبات المقياس

الذي بعنى اتساق إجابات المفحوصين للمقياس، أي ضمان الحصول على النتائج نفسـها

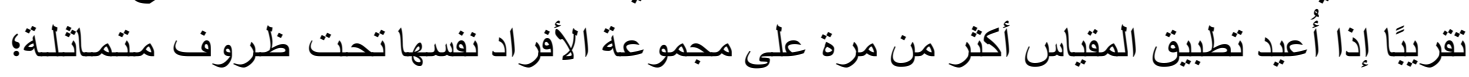

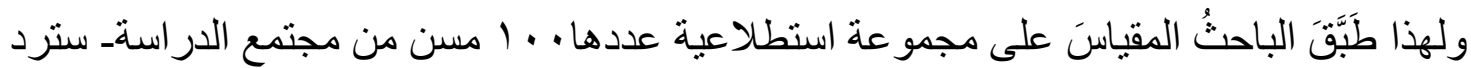

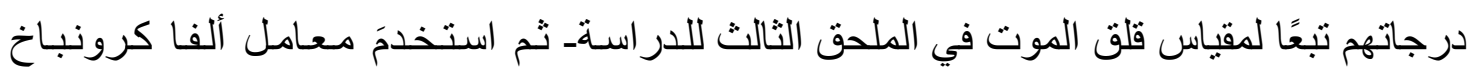

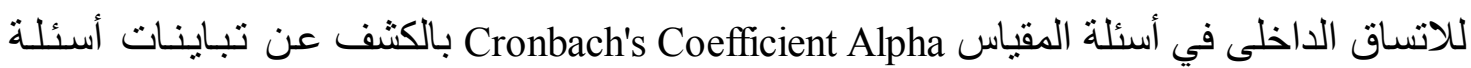

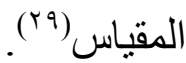

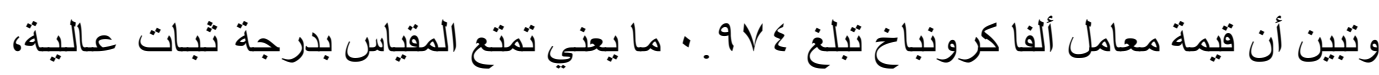

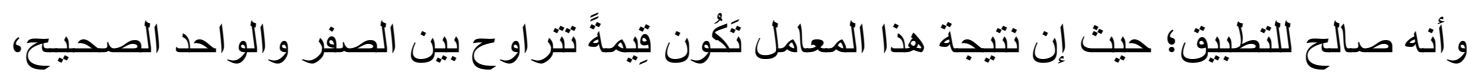

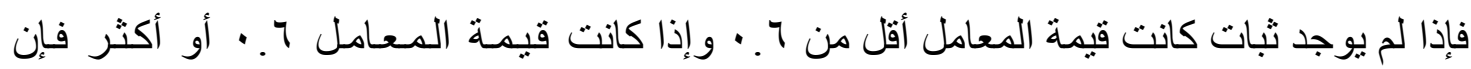
المقياس يتصف بالثبات، ويزيد الثبات كلما اقتربت القيمة من الو احد الصحيح(·r).

وتأكيدًا على ثبات المقياس بعد تعديله؛ استخدم الباحث طريقة التجزئسة النصفيـة بمعامل

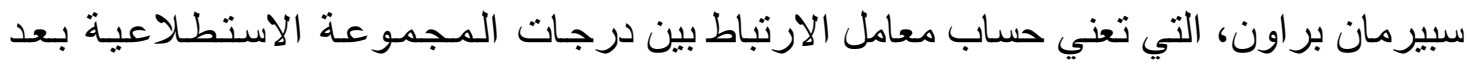

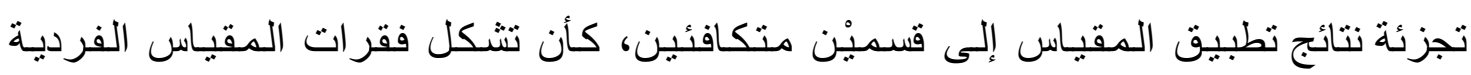

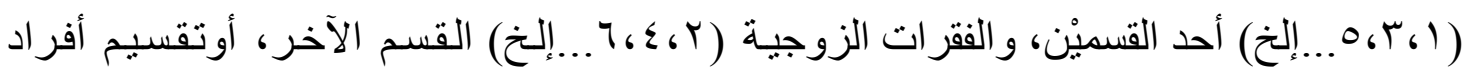

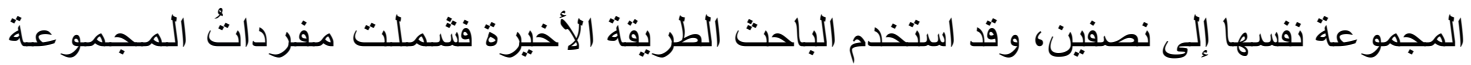

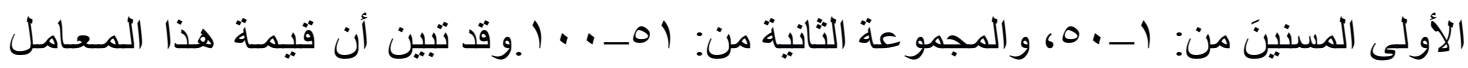
بلغت ؛0 90. · ما يؤكد تمتع المقياس بدرجة عالية من الثبات. 


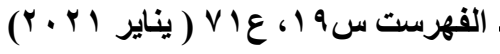

د. أحمد جابر حامد

\begin{tabular}{|c|c|c|}
\hline عدد أفراد العينة الاستطلاعية & معامل الثبات & الطريقة \\
\hline $1 \ldots$ & $.9 \vee \leqslant$ & ألفا كرونباخ \\
\hline $1 \ldots$ & $.90 \leqslant$ & لتجزئة النصفية \\
\hline
\end{tabular}

جدول( ( ): قِيَم معامل الثبات لمقياس قلق الموت المستخدم بعد تعديله.

وبذللك تكون مستويات قلق الموت بحسب المقياس المستخدم بعد تعديله لأغر اض الدر اسة كالآتي:

\begin{tabular}{|c|c|}
\hline معدلات قلق الموت & الارجات \\
\hline الفرد الغير مصـاب بقلق الموت & $\varepsilon r$ \\
\hline قلق الموت منخفض & $07-\varepsilon r$ \\
\hline قلق الموت متوسط & $V \cdot-O V$ \\
\hline قلق الموت مرتفع (مزمن أو شديد) & $\lambda \varepsilon-V I$ \\
\hline
\end{tabular}

جدول(r): مستويات قلق الموت بحسب المقياس بعد تعديله، ودرجات كل مستوى منها.

لا تَقِلٌُ نتيجة المقياس عن بعدرجة، التي تعني أن المسن غير مصساب بقلق الموت، أمسا

الدرجات منسع إلى

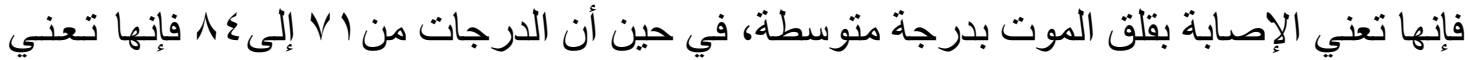
الإصسابة بقلق الموت بدرجة مرتفعة مزمنة.

وتتناول فقر اتُ المقياس - بعد تعديلهـ ثمانية أبعاد لقلق الموت، هى:

\begin{tabular}{|c|c|c|c|c|c|}
\hline عدد الأسئلة & المحاور/ الأبعاد & P & الأسئلة & المحاور/ الأبعاد & p \\
\hline 0 & الخوف من رؤية & 0 & 7 & التفكير في الموت & $T$ \\
\hline$r$ & الخوف من الدفن & 9 & $\bar{\Lambda}$ & كل ما بُدْكِّر بالموف من & $\bar{r}$ \\
\hline 0 & 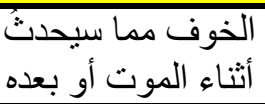 & $\mathrm{V}$ & $\bar{v}$ & الخوف من مسببات & $\mu$ \\
\hline 0 & الخوف من موت & $\Lambda$ & $\Gamma$ & المفاجئ أو قبل تحقيق الموت & $\varepsilon$ \\
\hline$\varepsilon r$ & \multicolumn{5}{|c|}{ مجموع فُقرات المقياس } \\
\hline
\end{tabular}

جدول(ب): أبعاد مقياس قلق الموت بعد تعديله، و عدد أسئلة كل بُعد. 


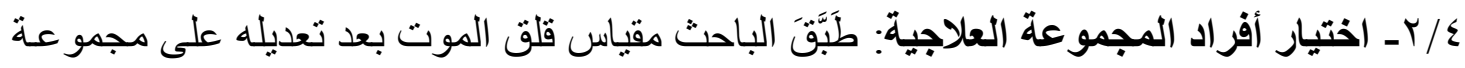

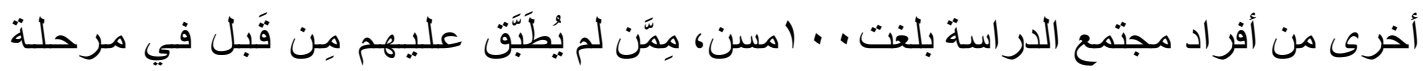

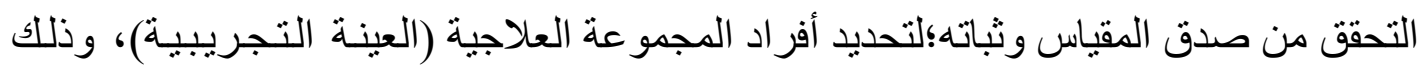

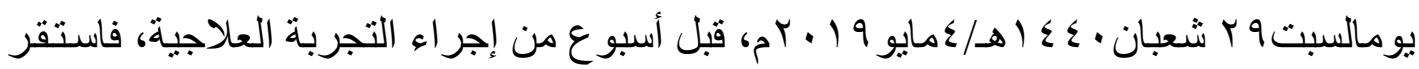

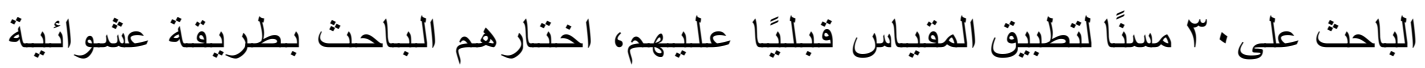
بسيطة،ممن يعانون قلق الموت بدرجة مرتفعة أو متوسطة بحسب نتائج المقياس،على أن يتسم

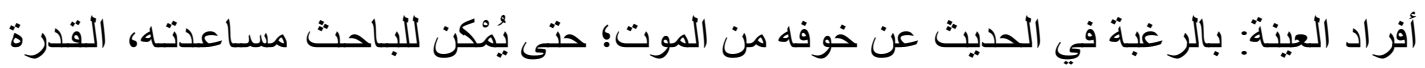

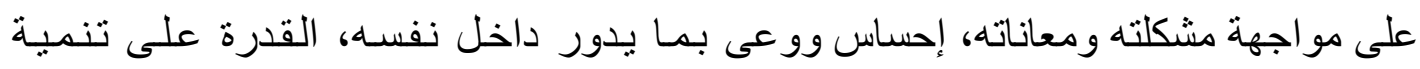

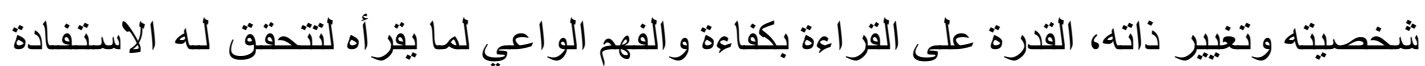

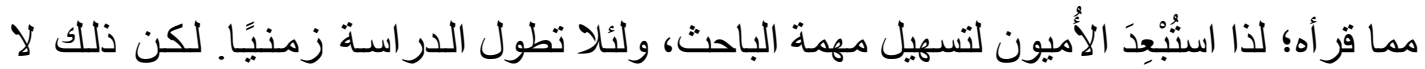

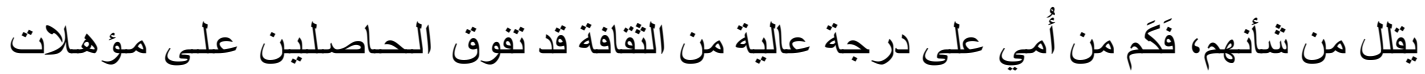

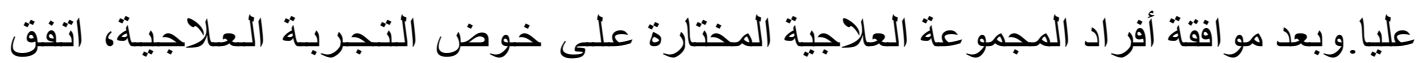
البحث معهم على تاريخ أول جلسة علاجية.

\begin{tabular}{|c|c|c|c|c|c|c|c|}
\hline النسبة المئوية & العدد & المتغير & البيان & المئوية & العدد & المتغير & البيان \\
\hline$\% 07.7$ & IV & 70.7. & \multirow{4}{*}{ العمر } & $\% \vee\urcorner . \vee$ & $\overline{T r}$ & ذكر & \multirow[t]{2}{*}{ الجنس } \\
\hline$\%$ \%Y.V & $\Lambda$ & $V \cdot-77$ & & $\%$ \%T.Y $^{\prime}$ & $\mathrm{V}$ & أنتى & \\
\hline \multirow{2}{*}{$\% 17 . \vee$} & \multirow{2}{*}{0} & \multirow{2}{*}{ Vo_vi } & & $\%$ \% Y.V & $\Lambda$ & متو سؤ هل & \multirow[t]{3}{*}{ التعليمي } \\
\hline & & & & $\% 1$ & $r$ & المؤو هوق & \\
\hline$\% 1 \ldots$ & $\mu$ & \multicolumn{2}{|c|}{ مجموع أفراد أي بيان } & \%ฯT.r & 19 & عؤ هلٍ & \\
\hline
\end{tabular}

جدول(ع): الخصائص الثخصية لأفر اد العينة التجريبية:

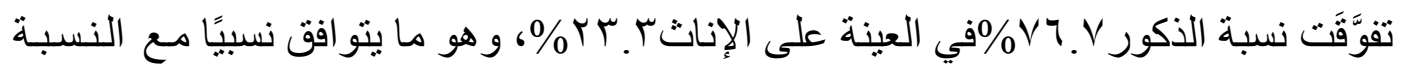

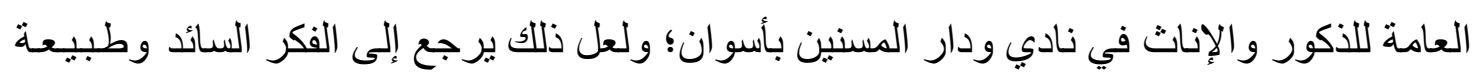

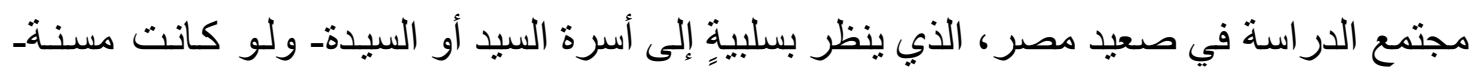
الذين يذهبون إلى هذه المؤسسات.

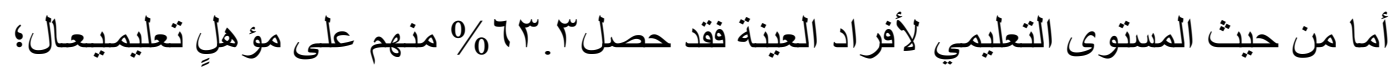

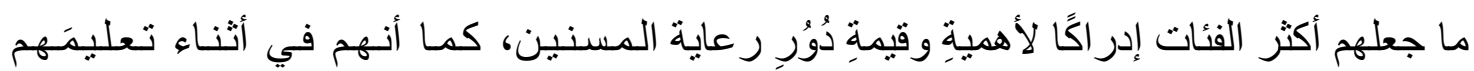


وقر اءاتهم قد مَرَّوا كثيرًا على ما يتعلق بالموت من أمور وموضو عات؛ و لا غَرو أنهم أكثر فئسات

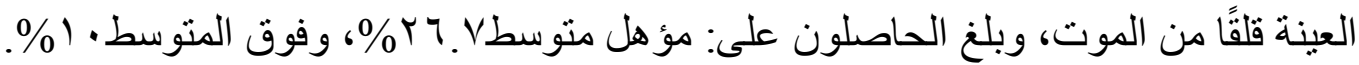

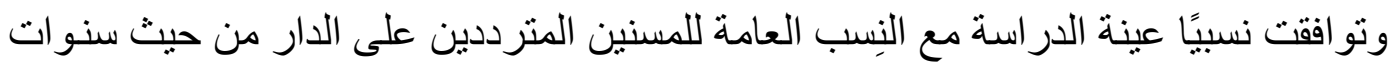

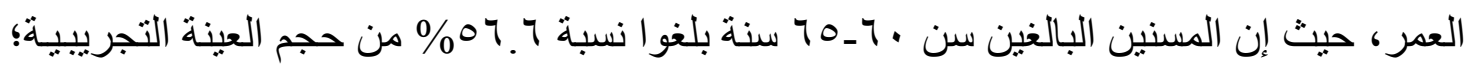
حيث تمكنَّهم مقدرتهم الصحية على الخروج إلى دار المسنين، بينما تقل تللك المقدرة كلمـا زاد

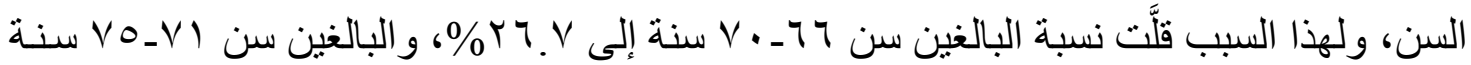

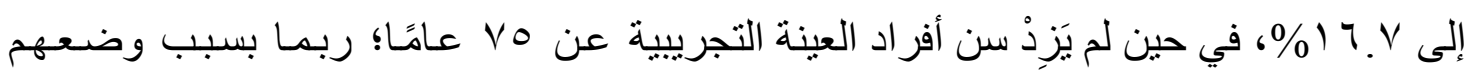
الصحي الذي قد يمنع بعضهم من الحركة الطبيعية، و الذهاب إلى دار المسنين. r / هـ التطبيق القبلي للمقياس: طبَّقَ الباحث مقياس قلق الموت على أفر اد العينـة التجريبيـة لاستخر اج درجات المسنين ونتائج هذا التطبيق قبل إجراء التجربة العلاجية، وهي التنائج التي

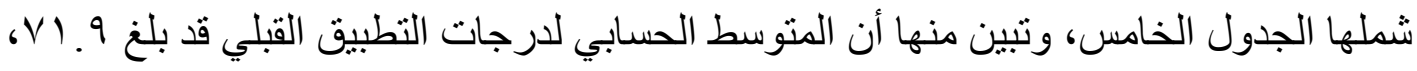

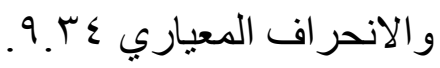

T/ 7ـ التخطيط لبرنامـج العلاج بالقراءة: مرَّ تخطيط البرنامج القر ائي بالخطوات الآتية: r/ أـ أن يتعرف المسن طبيعة المرحلة السنية التي يعيشها بكل احتبـاجاتها ومشكلاتهـا، والعلاج بالقر اءة. بـالدعم النفسي وتتمية الثخصية، من خلال مساعدته في إدر الك حقيقة ما يعانيه، وطر ائق التغلب عليه.

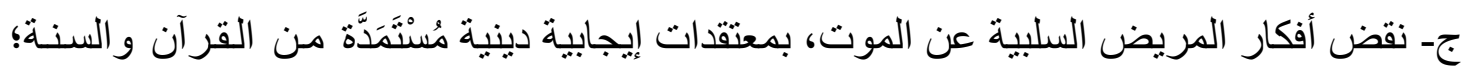
تزيد تقبله لله.

ولتحقيق هذه الأهداف استغل الباحث عدة سمات يتصف بها المسلمون عمومًا، هى ('ا"): أ ـ الإيمان بالله وبالقضاء و القدر، وهو في حد ذاته علاج.

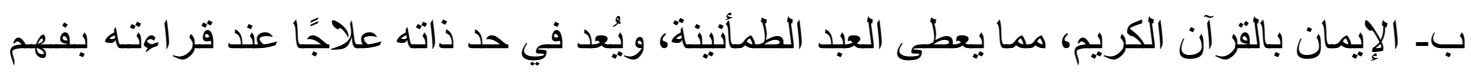
وتدبر. ج- الإيمان باليوم الآخر، حيث يُّرِكِ العبد أنه مأجور عما أصابه في الدنيا، ممـا يسـاعده على الصبر 


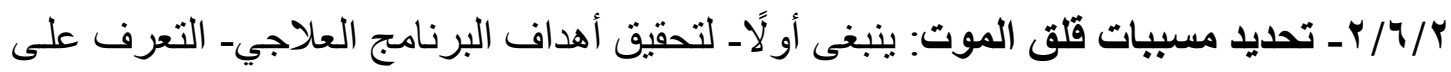

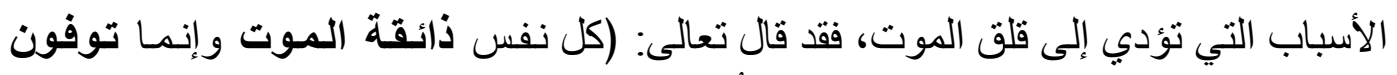

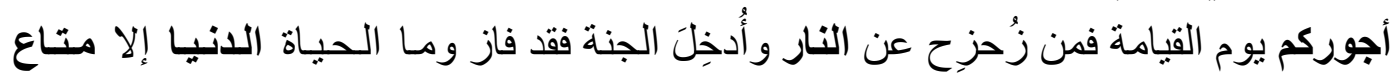

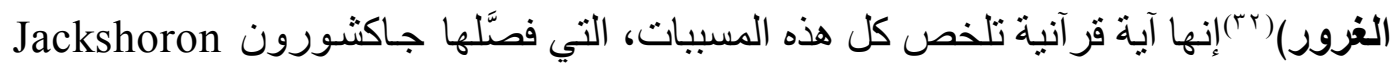
وأرجعها إلى أحد أو أكثر مما يأني (سبّ):

أ)- الخوف من الاحتضار و آلامه، وفجأة الموت.

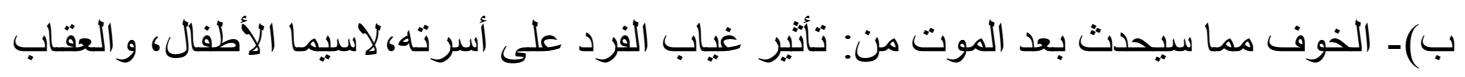
الإلهى على الأعمال الدنيوية، و المجهول مما سيحدث بعد الموت، والوحِدة، القبر ويوم القيامة. ج)- الخوف من نهاية الحياة الدنيا ومباهجها. ويضيف الباحث سبيًا رابعًا، هو أن الفرد يقلق من الموت إذا يئس من رحمة الله. علمًا بأنه قد تتعدد المسببات التي تدفع المرء للقلق من الموت. و استتادًا على مسببـات قلق الموت شرع الباحث في تصميم البرنامج العلاجي المقترح. r/ ؟/ r- تحديد محتوى البرنامج القرائي وترتيبه: حيث رُتبّبَ بطريقة تكثف عوار الأفكار

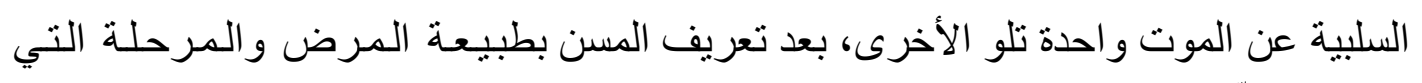
يعيثها، فرُتِّبَ محتوى البرنامج كالآتي: أـ المسنون، وقلق الموت، و العلاج بالقر اءة. بـ القنوط من رحمة الله، والظن بحتمية العذاب بعد الموت؛ بسبب كثرة ذنوب ونوب العبد في الدنيا. ج- الخوف من مجهو لات الموت وفجأته و ألوان العذاب، كعذاب القبر وأهو ال يوم القيامـة و النار.... إلخ. دـ الخوف من الموت؛ بسبب التعلق بمباهج الدنيا، والخوف على الأسرة، وبخاصةً الأطفال.

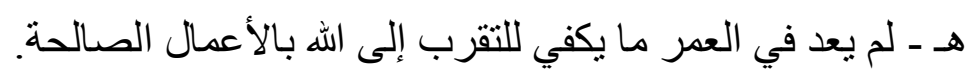




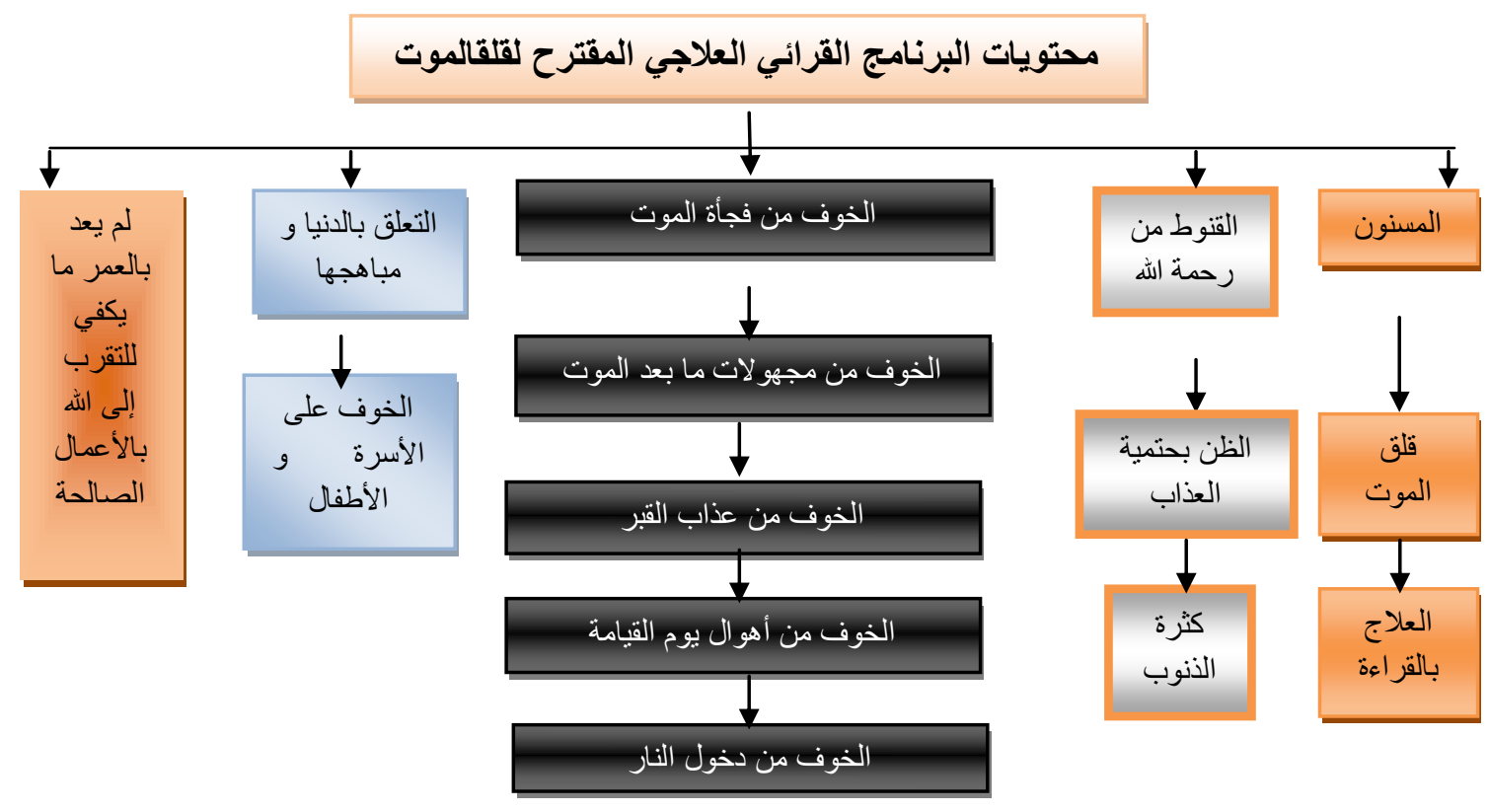

شكل( (1): محتويات البرنامج العلاجي المقترح لقلق الموت.

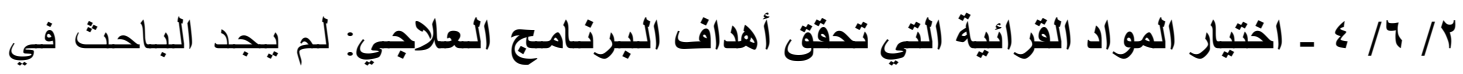

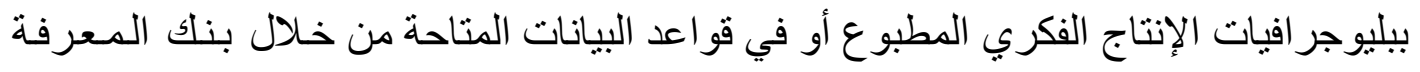

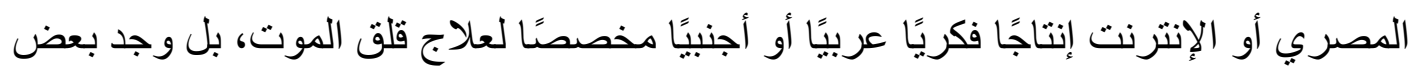

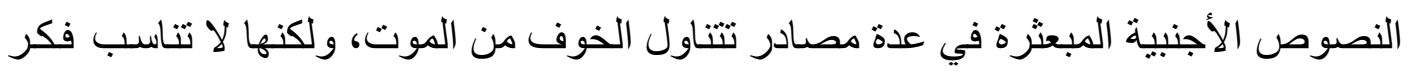

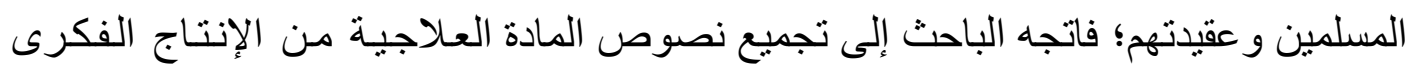

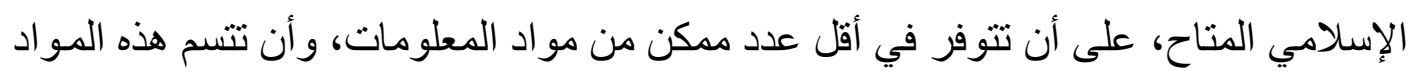

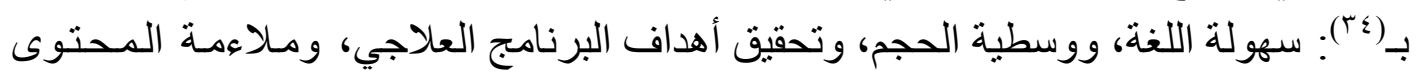
لطبيعة المسنين وقدر اتهم.

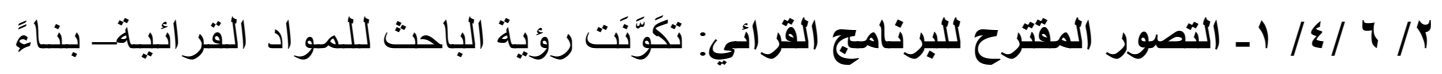

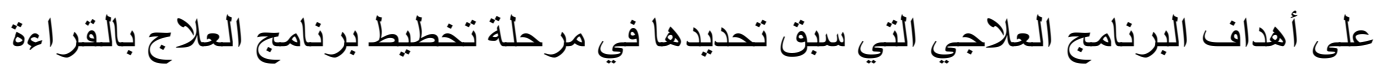
ـ كالآتي:

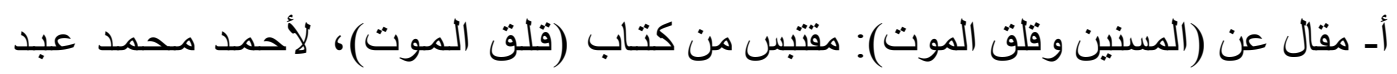

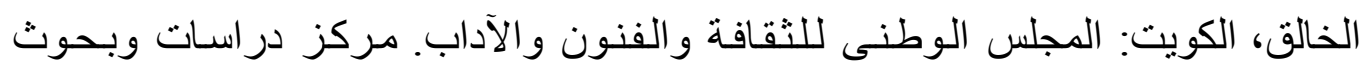

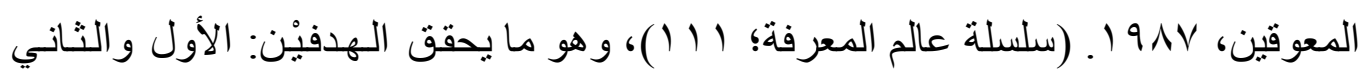
للبرنامج العلاجي السابق الإثارة إليه. 


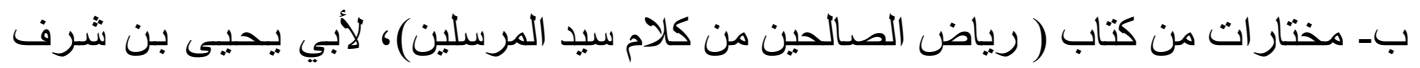

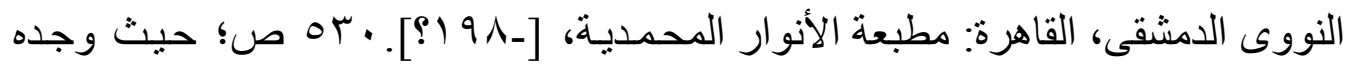

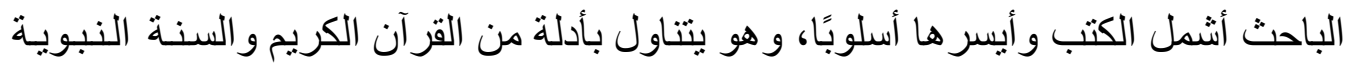

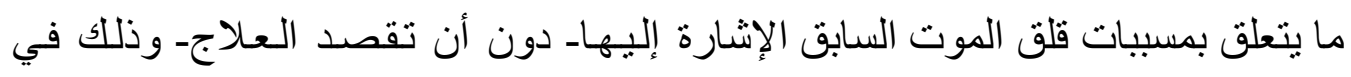

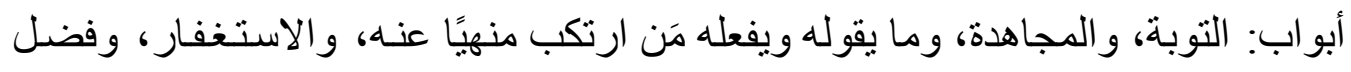

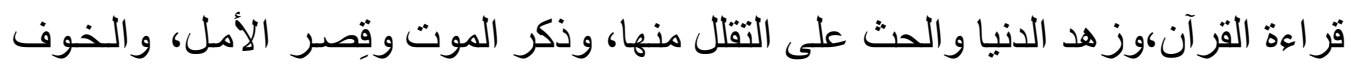

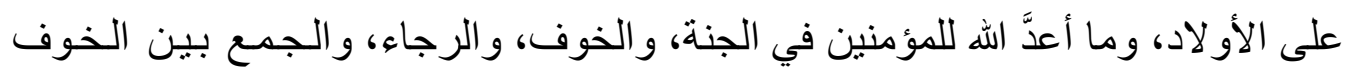

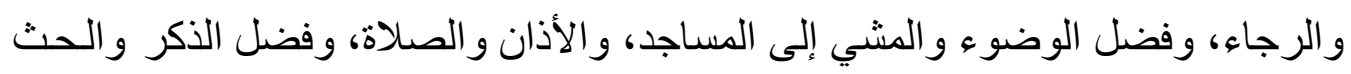

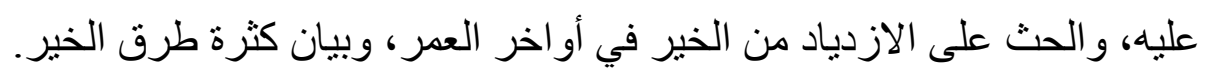

ج- كتاب (أخي المسلم، كيف تفوز بنعيم الجنـة) تأليف: عبده أحمد الأقرع. طب، المدينـة

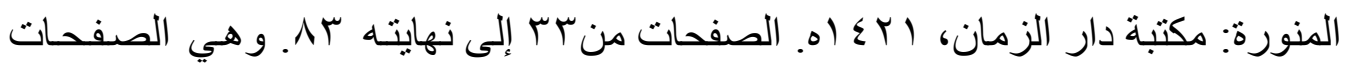

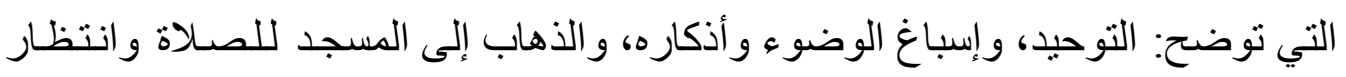

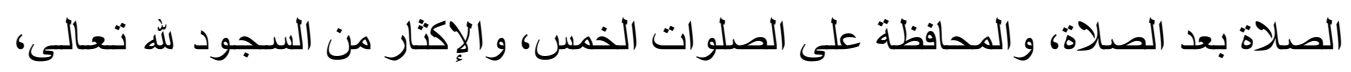

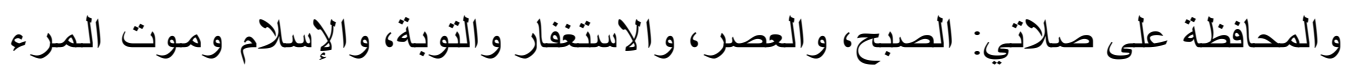

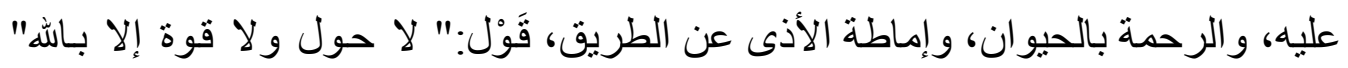

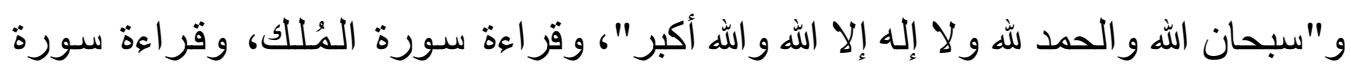

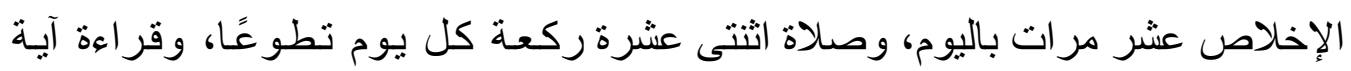

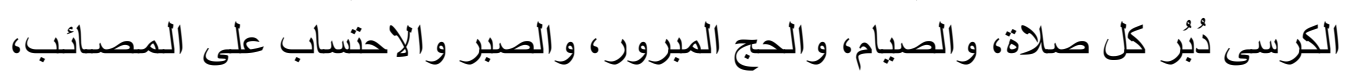

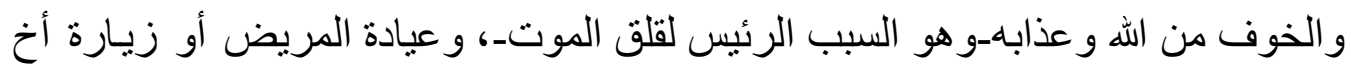

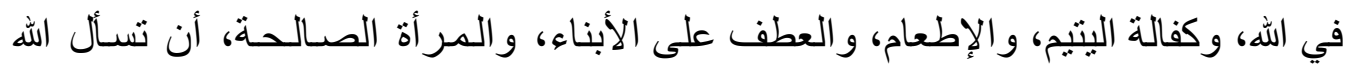

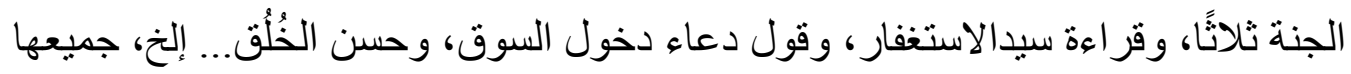

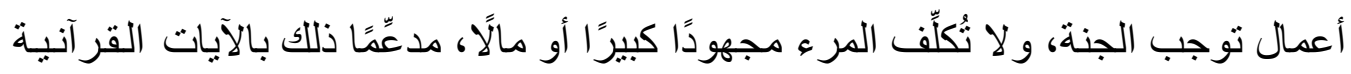
و الأحاديث النبوية. وهو ما يحقق الهدف الثالث للبرنامج العلاجي السابق الإشارة إليه.

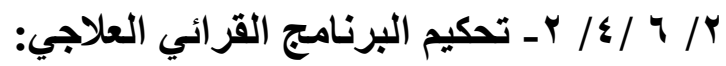

عَرَضَ الباحثُ البرنامجَ القرائي على مجموعة من أسـاتذة الجـامعات المصريـة(***) لأخذ أنذ

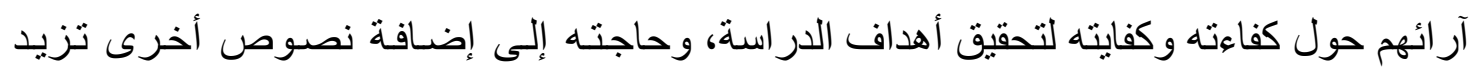

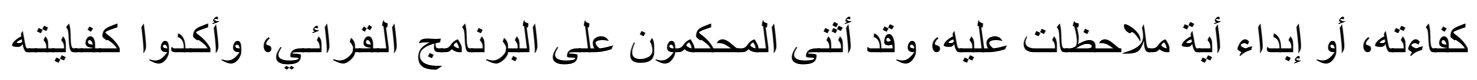
لتحقيق أهداف الدراسة، ولم يُبْدو ا ملاحظات عليه. V/T - التخطيط للجلسات العلاجية: خَطَّطَ الباحث لأن تسير الجلسات على النحو الآتى: 


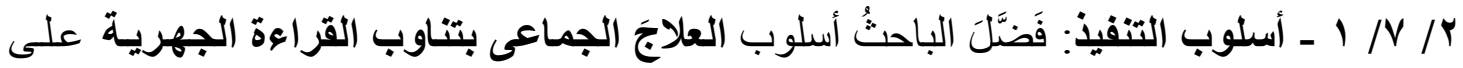

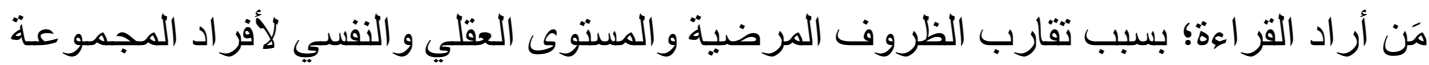

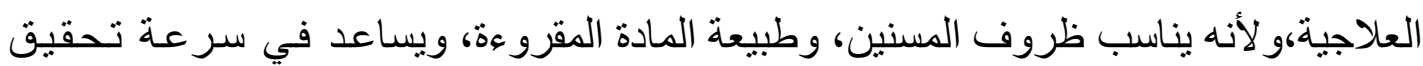

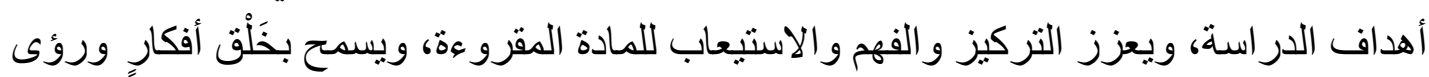

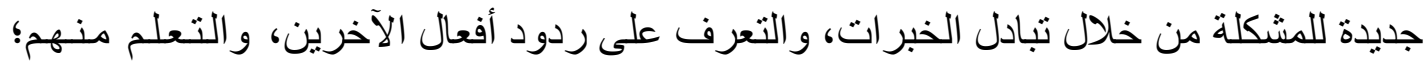

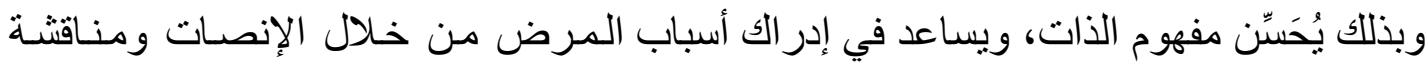

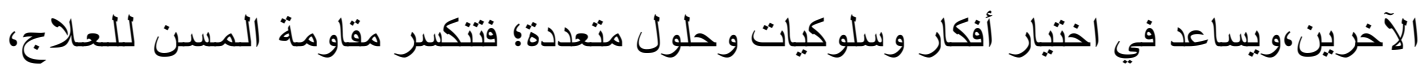

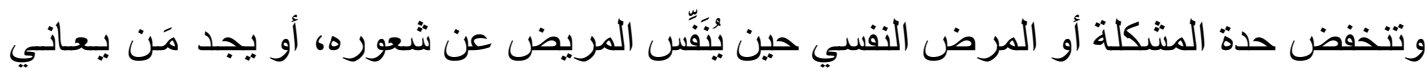
مثله أو أكثر منه، فيحاول مساعدة غيره للتغلب على المشكلة، وهو في حقيقة الأمر يساعد نفسه في الثفاء.

وقد تلت قر اءةً النصوصِ مناقشاتُ وتعليقاتُ جماعية، و إبداء الآر اء والأفكار الإيجابية؛ لأنهـا

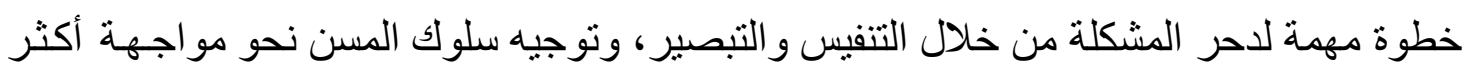
فاعلية لأفكاره السلبية. r/ Y Y مدة الجلسة العلاجية: خطط الباحث لمدة الجلسة بحيث لا تتخطى ساعة زمنية؛ لتناسـب طاقة تَحَمُّل وتركيز المسنين، وبمعدل ثثلاث جلسات أسبو عيًا؛ لنئلا يَمَلُّو ا. r/ / r / ـ علاقة الباحث بالمجموعة العلاجية: حرص الباحث منذ البداية على تطوير علاقته

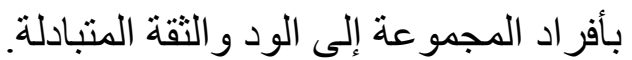

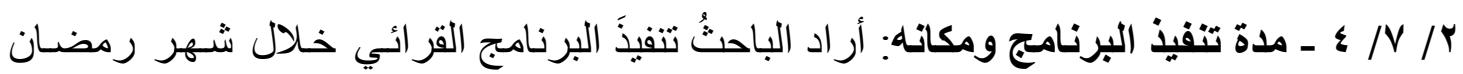

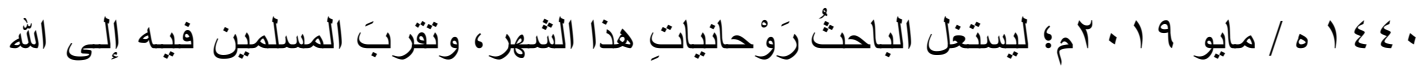
في تحقيق أهداف الدراسة، ثم تتبعه جلسة تقييمية بعد مرور ثثلاثة أسابيع، حيث التنفيذ في نـادي ودار المسنين بمدينة أسو ان؛ للأسباب المشار إليها سابقًا.

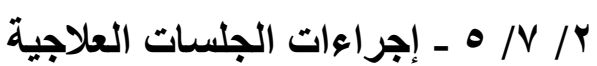

تُقَسَّم كل جلسة علاجية إلى أربعة أجزاء: يُخصَّص الأول منها للترحيب بالمجمو عة العلاجية،

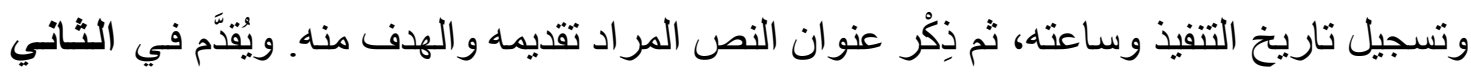

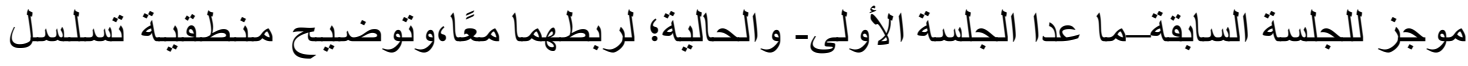
وحدات البرنامج،ثم يتناوب المسنون على قر اءة نص المادة العلاجية، ومناقشته و التعليق عليه في ولي الجزء الثالث، ثم يلخص الباحث في الرابع النقاط المستفادة من الجلسة، التي تنتهـى بـالتكليفات الشخصية، ثم تسجيل مدة الجلسة، وتحديد مو عد الجلسة اللاحقة. 
T/ / / / محتوى الجلسات

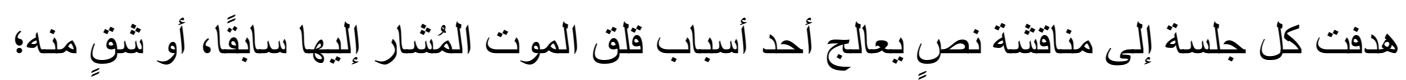

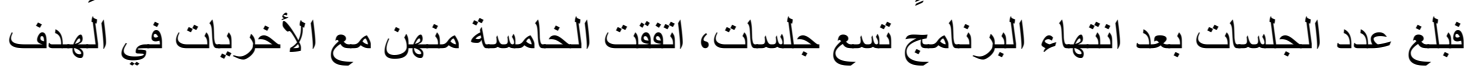

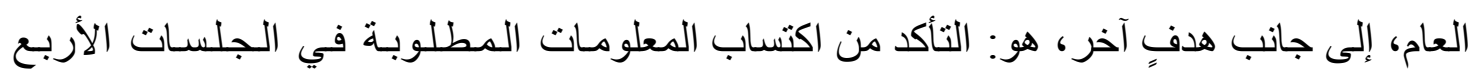

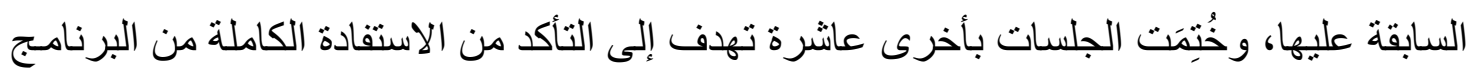
العلاجي، وإجر اء التطبيق البعدي؛ وبذلك بلغ مجموعها عشر جلسات علاجية.

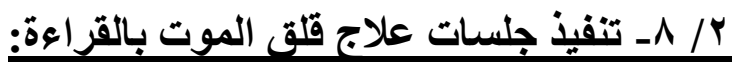

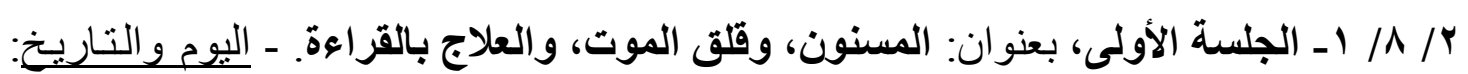

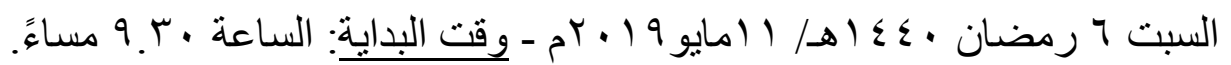

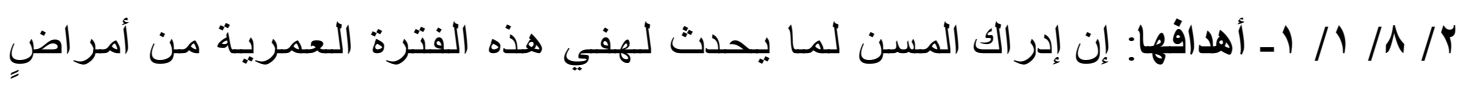

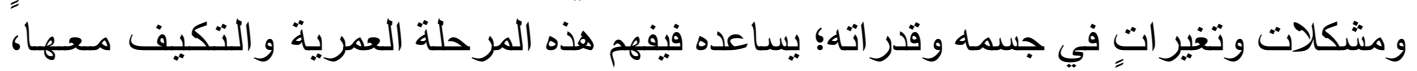

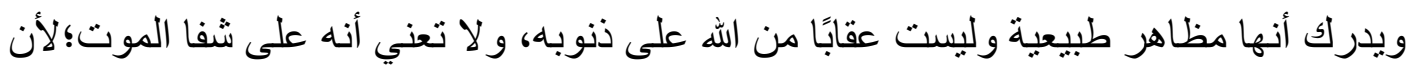
هذه الفكرة تسبب مرض قلق الموت الذي يعاني منه كثير" من المسنين دون أن بدركو أنه أحد

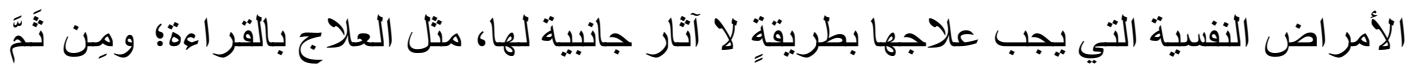

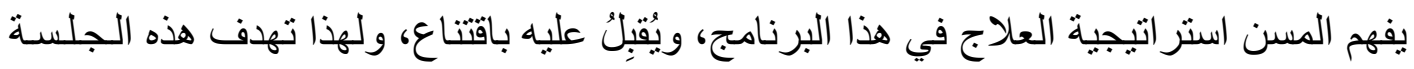

$$
\text { إلى تحقيق الأهداف الآتية: }
$$

أـ أن يفهم المسن طبيعة المرحلة التي يعيشها، من حيث: التعريفات، والاحتياجات، و المشكلات.

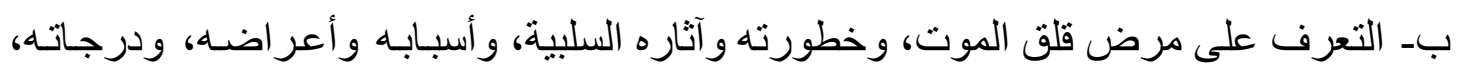

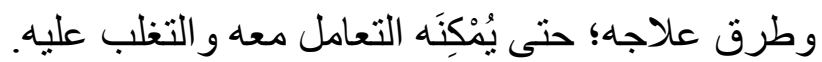
ج- إبراز قيمة العلاج بالقراءة، وخطو اته كإحدى طرق العلاجه. دـ زيادة اقتناع المسن وقبوله لعلاج قلق الموت بالقراءة، والارتقاء بمستوى ثقتهـه في الباحث و إجر اءات التجربة.

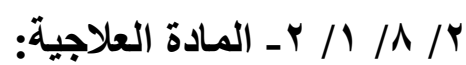

مقتطفات من كتاب (قلق الموت) تألبف: أحمد محمد عبد الخالق، ذُكِرَت كاملةً في "الجلسـة الأولى بالملحق الثاني للار اسة"، تنتاول:

أـ المسنين: التعريف، القيمة و المكانة، و الاحتياجات، و المشكلات، و وكانة المسنين في الإسلام.

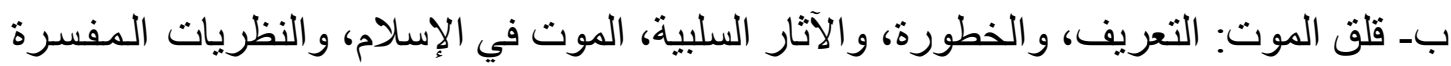
لأسباب قلق الموت، و الأعر اض، ودرجات ولفورة، والات المرض، وطرق العلاج. ج- العلاج بالقر اءة: تعريفه، ومميز اته، وخطو اته. 


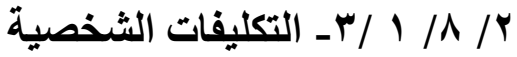

نَحِّمن فِكْرَك أنكصت مسنًا، فهذا تطور طبيعى جَبَلَكَ الله تعالى عليه، ولا يعني أبدًا أنك

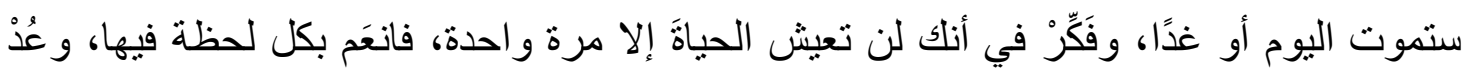

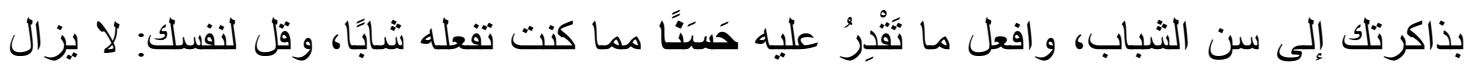

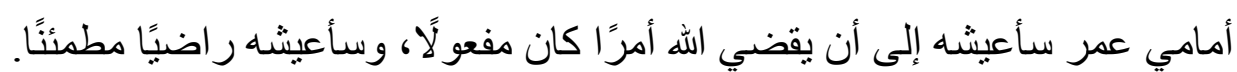
- وقت نهاية الجلسة: الساعة • ب. • ( مساءً ـ مدة الجلسة: • ج دقيقة

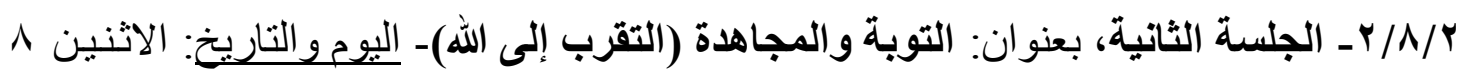

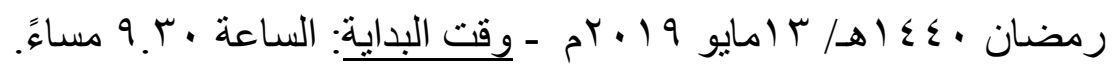

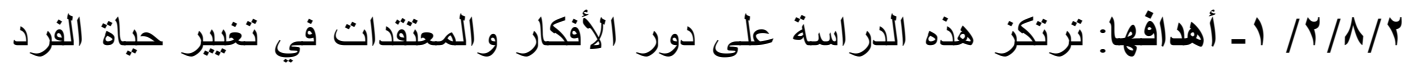

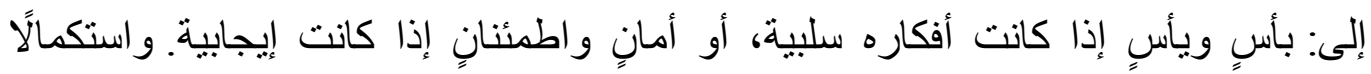

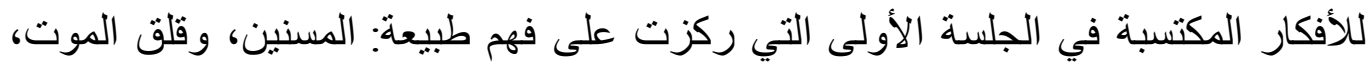

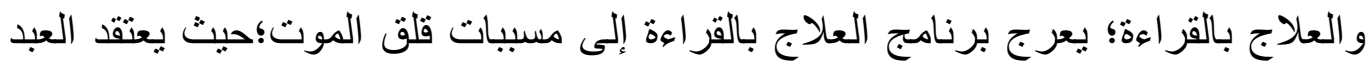
أن: كثرة الذنوب، و الابتعاد عن ربه فيما مضى من الحياة؛ سيلحقانه بعذاب الله.

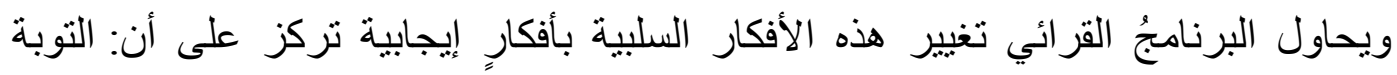

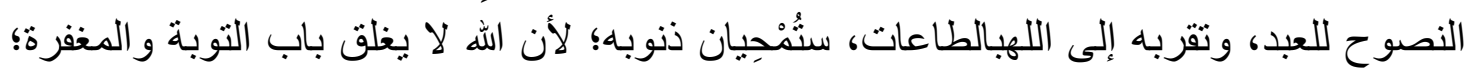
لهذا تهذف هذه الجلسة إلى: أـ أن بدرك المسن أن الله لا يغلق باب التوبة أمام عبده، بل يفرح بتوبته.

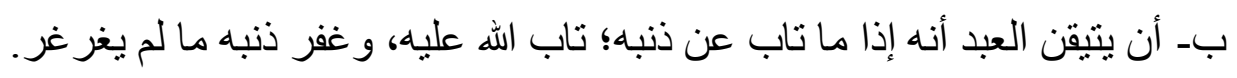
ج- أن بيتوب المسن إلى الله توبةًة نصوحًا من كل ذنوبه؛ ليغفرَ اللهُ له ما مضىى. دـ أن يتقرب العبد إلى الله بالطاعات، فيتقرب الله منه ويحبه. هـ ـ التأكيد على أن: "خير الناس مَن طال عمرهو وحَسُنَ عمله".

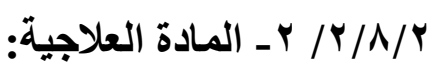
أحاديث من بابيّ: التوبة، و المجاهدة (التقرب إلى الله) من كتاب (ريـاض الصـالحين) التي

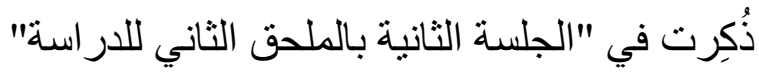

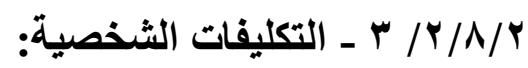
أـ ثُب إلى الله من كل ذنوبك الماضية، وضع في يقينك أن الله قد قَبِلَ توبتك و غفر للك.

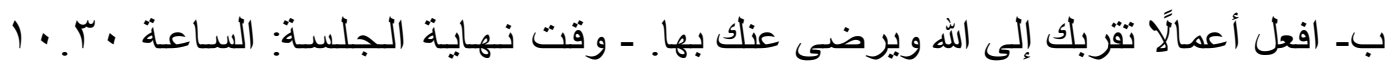

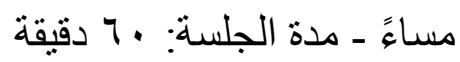




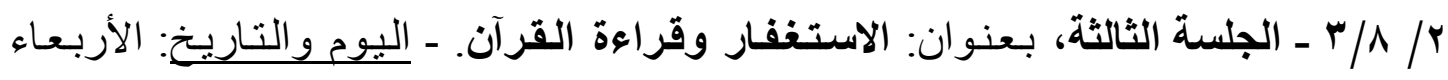

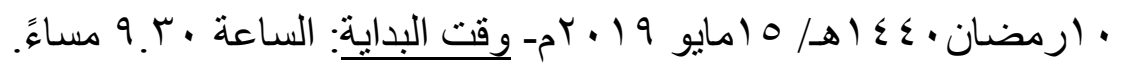
ץ/ א/ ץ/ 1 ـ أهدافها: استكمال للجلسة الثانية، التي هدفت إلى نبذ فكرة أن الله سيعذب العبد

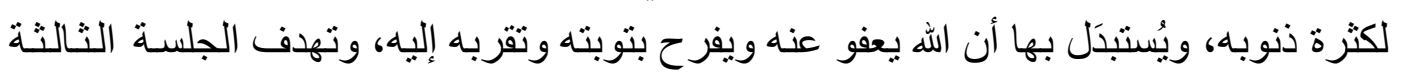

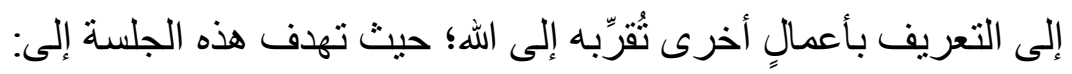
أـ الاستعانة بالاستعاذة من الثيطان؛ لطرد وساوسه عن الأفكار السلبية أو فعل الذنوب.

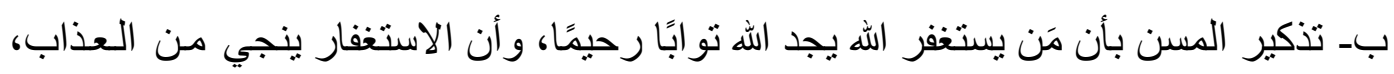

$$
\text { ولو في الكبائر. }
$$

ج- تعليم المسن طرق: الاستعاذة من الثيطان، والاستغفار كما وردت عن الرسول صلى الله عليه وسلم. دـ أن يدرك المسن عِظَم فضل قر اعة القر آن عمومًا، وبخاصةٍ سورة المُلك للنجاة من العذاب

$$
\text { بعد الموت. }
$$

هـــ أن يداوم المسن على الاستعاذة من الثيطان، و الاستغفار ، وقر اعة القرآن.

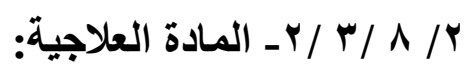

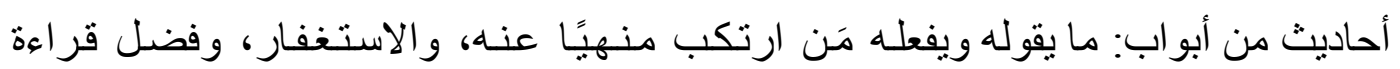

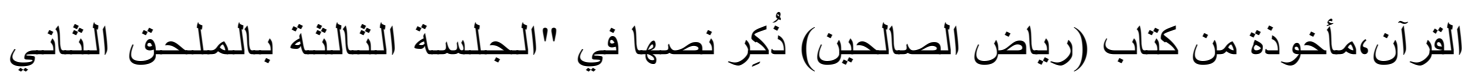

$$
\text { للار اسة". }
$$

r/

أـاستعذ باله كلما نزغلك الثيطان لفعل ذنب؛، أو للتفكير السلبي عن الموت أو عذاب اله أو أو الهو الآخرة.

بـ استغفر الله سبعين مرة، واقر أ جزءًا من القرآن كل يوم. ج- داوم على قر اءة سورتى: المُللك، و الدخان مرة كل ليلة. - وقت نهاية الجلسة: الساعة • بـ. • (مساءً ـ مدة الجلسة: • ب دقيقة

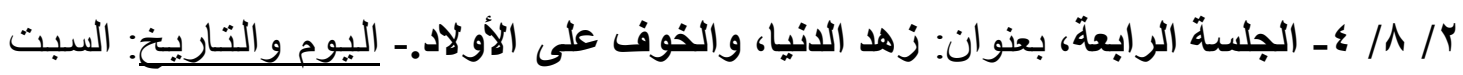

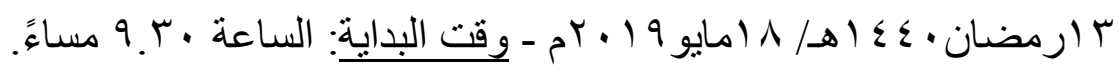

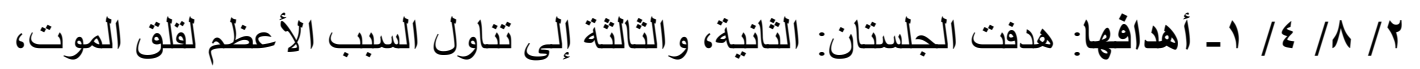


و هو يأس المسن من مغفرة الله على الذنوب السابقة وقبول توبته؛ فيوقن بالعذاب، وتتنقل

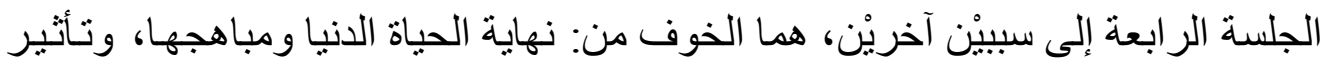

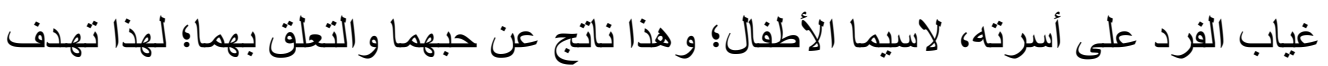
هذه الجلسة إلى توضيح أن الدنيا والأولاد فتنة زائلة، إذا انشغل بهما العبد عن عن الله لقي

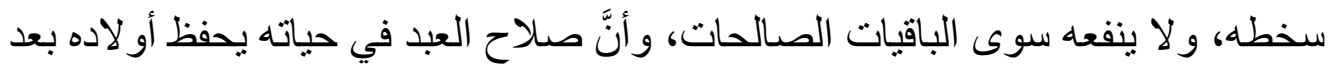
مماته؛ لذا تهدف هذه الجلسة إلى لى لئه أـ التر غيب في الحياة الآخرة الدائمة، وزهد الدنيا الزائلة التي لا ينفع منـها سوى البـاقيات الصالحات. ب- ضرب أمثلة لز هد الدنيا من حياة النبي وصحابته الكر ام.

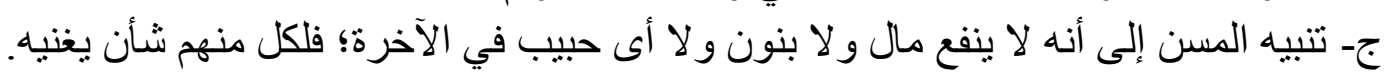
دـ تحفيز المسن على التقوى و الصلاح في حياته؛ حتى يحفظ الهه له ذريته بعد مماته.

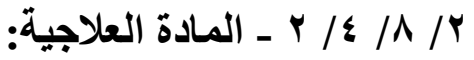

أحاديث من (باب فضل الز هد في الدنيا)، مأخوذة من كتاب (رياض الصالحين)، و آيات من

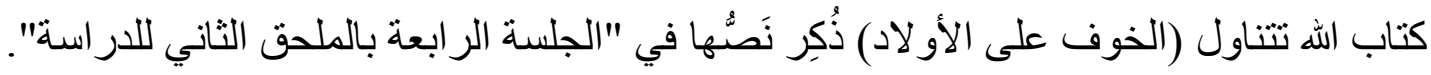

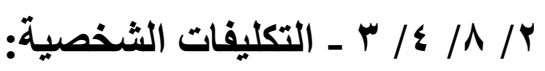

أـ ذَكِّر نفستك دائمًا بأن الدنياز ائلة، ولن ينفعك منها سوى عملك الصالح.

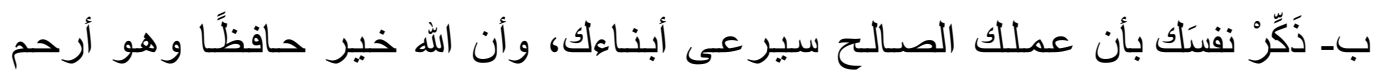

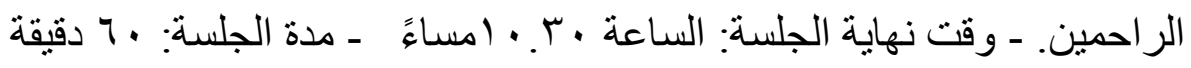

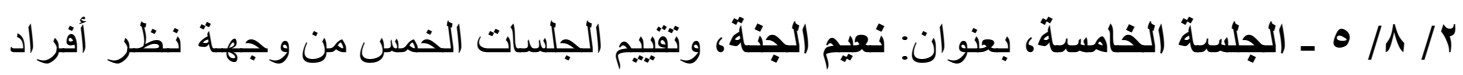

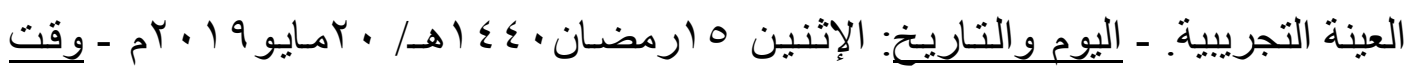
البداية: الساعة • ب. 9 مساءً.

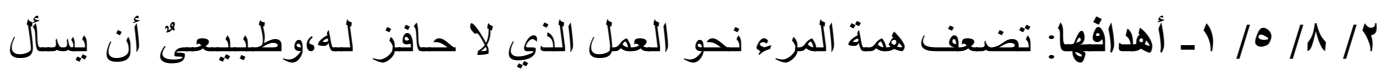

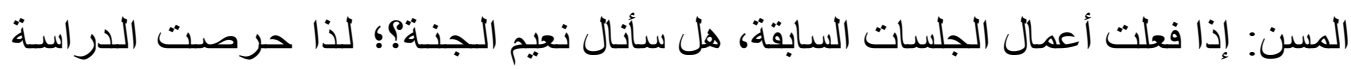

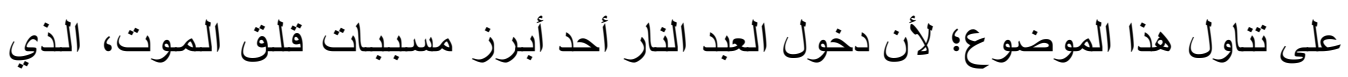

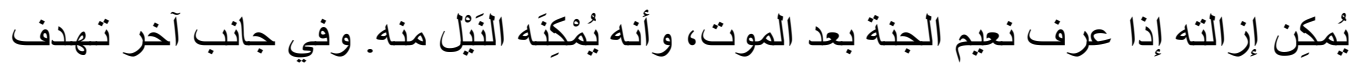

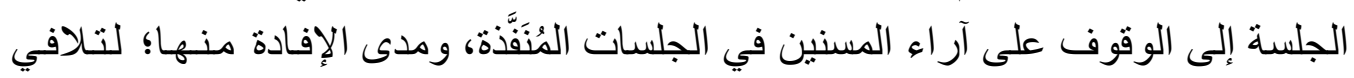
سلبياتها، ولزيادة فاعلية الجلسات اللاحقة؛ لذا تهدف هذه الجهاء الجلسة إلى: أـ أن يتعرف المسن على مَن سيَذْخُل الجنة، وصفة أهلها. 


$$
\text { ج- جـ أن بتصور المسن بعضيًا من نعيم أهل الجنة. }
$$

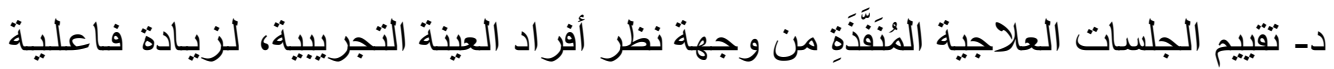

$$
\text { الجلسات اللاحقة. }
$$

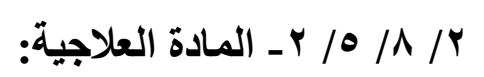

أحاديث من (باب ما أعَدَّ الله للمؤمنين في الجنة)، مأخوذة من كتاب ( رياض الصالحين)

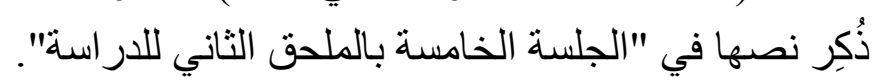

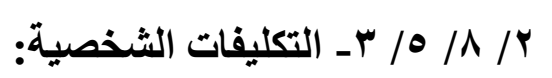

اغمض عينلك، تخيل نعيم الجنة و أنت مُنَعَّمُ فيها، وصوِّر لنفسك أنك كلما تَمَنَّبت شيثًا

$$
\text { وجدته بين يديك. }
$$

- وقت نهاية الجلسة: الساعة • ب. • (مساءً ـ مدة الجلسة: ـ 7 دقيقة.

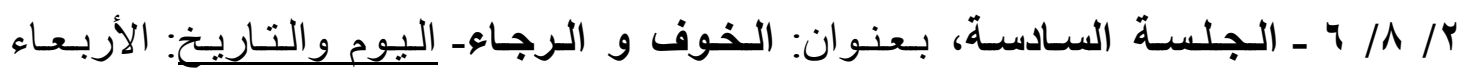

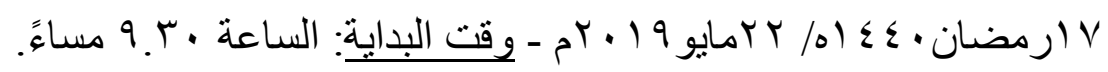

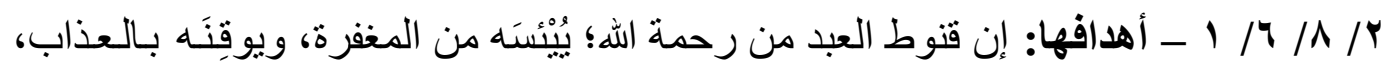

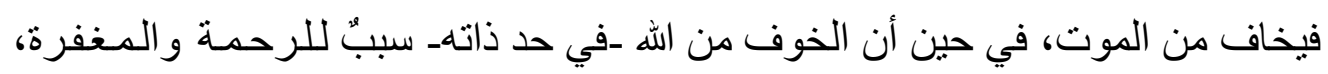

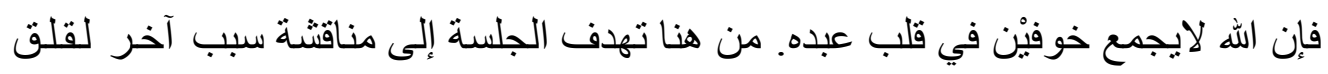

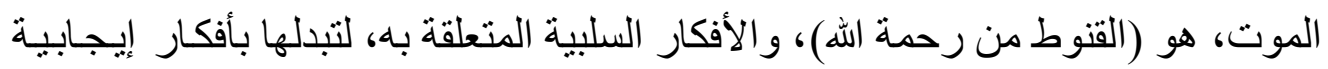

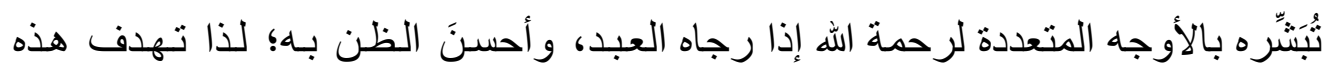
الجلسة إلى: الإن

$$
\text { أـ النهى عن القنوط من رحمة الله؛ فإن الله يخفر الذنوب جميعًا. }
$$

بـ زيادة يقين العبد بأن الخوف من الله إذا اجتمع مع الرجاء وحسن الظن؛ نال المغفرة

$$
\text { و الرحمة و الجنة. }
$$

ج- التأكيد على أن مَن شهد لله بالوحدانية، ولمحمد بالرسالة؛ دخل الجنة، وحُرَِّت عليه النار. دـ التذكير بأن الله خلق الرحمة مائة جزء، أخَّرَ منها تسعة وتسعين ليرحم بها عبـاده يوم 
أحاديث من أبو اب: (الخوف) و(الرجاء)، و(الجمع بين الخوف و الرجاء)، مـأخوذة من

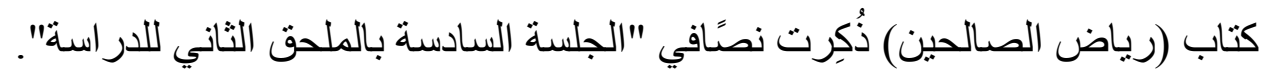

\section{r/}

أـ لا تبأس أبدًا من رحمة الله، وتيقن من أن الله سيخفر للك.

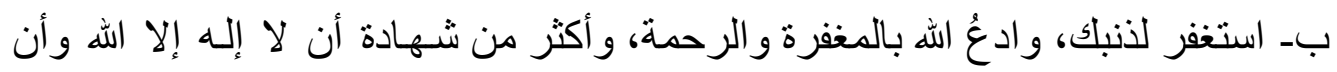
محمدًا رسول الله.

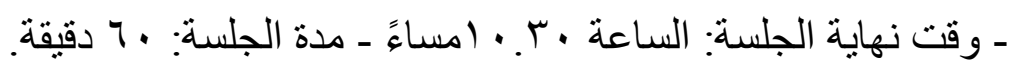

ץ/ ^/ Vـ الجلسة السابعة، بعنوان:الوضوء، والمشي إلى المسـاجد، والأذان، والصـلاة، وذكر

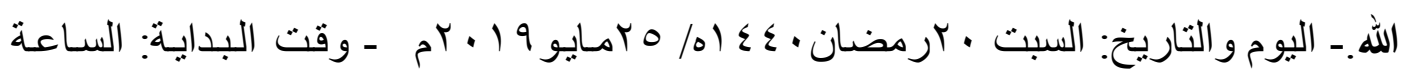
.

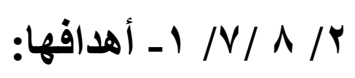

إن تفكير المسن في أنه بلَغ أرذل العمر، ولم يتبـق منـه مـا يكفي لعمل الصـالحـات

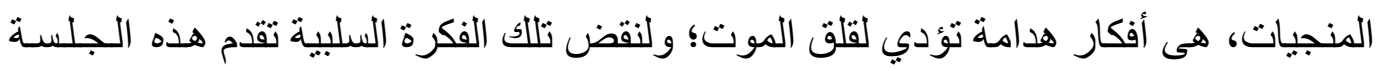

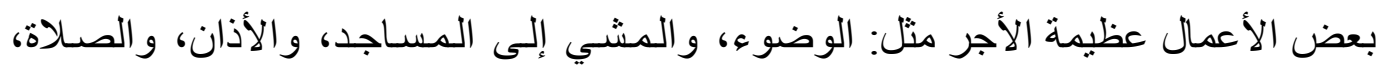

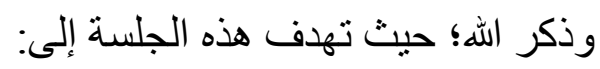

أـ بيان فضل كل من: الوضوء، و المشي إلى المساجد، و الأذان، و الصلاة، وذكر الله في محو الذنوب، ورفع الارجات.

بـ التعريف بالأذكار التي يعظم أجر ها عند اللهـ رغم سهولة قولهاء و إيضـاح أَجْرها. ج- حَثُّ المسن على الإكثار من هذه الأعمال؛ لِعِظَ أجر ها عند الله.

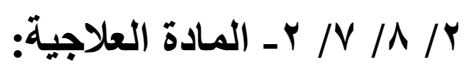
أحاديث من أبو اب فضل: (الوضوء)، و(المشي إلى المساجد)، و(الأذان)، و(الصلو ات)،

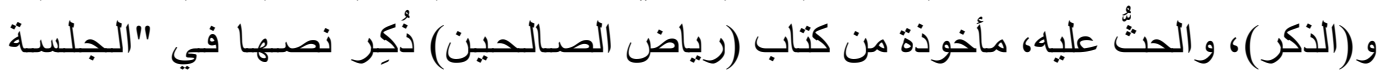

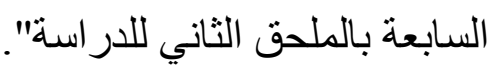

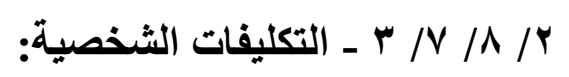
حاول أن تكثر من: الوضوء، الخُطى إلى المساجد، والصلاة، وذِكْر الله قََْر استطساعتلك، موقنًا بعفو الله عنأك.

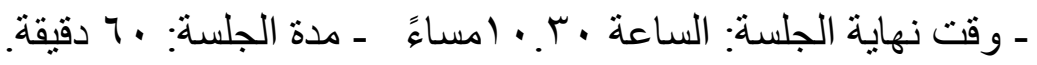




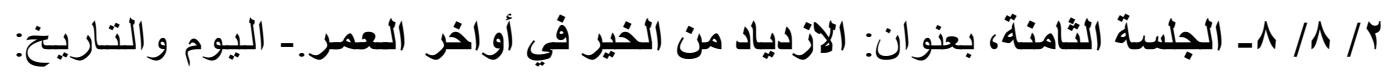

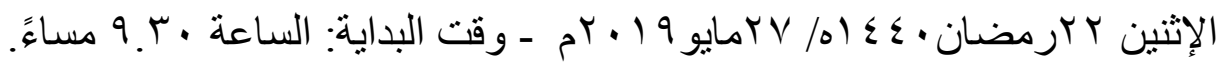

$$
\text { - L أهدافها: }
$$

أـ تستكمل هذه الجلسة ما بدأته الجلسة السابعة في تفنيد الأفكار السلبية التي تتعلق ألتأن:

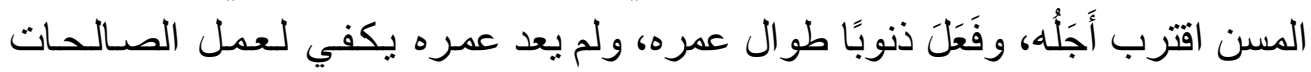

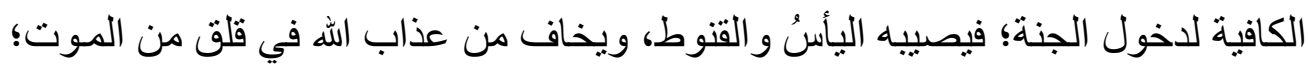
لذا تحاول هذه الجلسة تغيير تللك الأفكار بأفكار إيجابية من خلال تحقيق الأهداف الآتية: تنبيه المسن إلى أن العبدَ يُبعث يوم القيامة على مامات عليه.

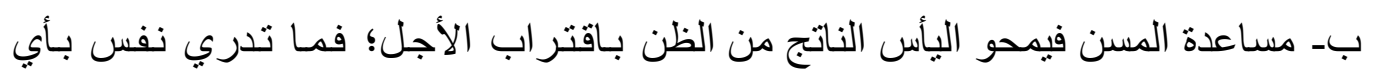

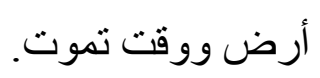

ج- التذكير بأن أى عبدٍ يفعل الصالحات و السيئات، فلا تنظر للسيئات فقط. دـ حثُّ المسن على فعل أعمال الخير في أو اخر عمره، كما وردت في آيات الله وأحاديث

$$
\text { رسوله. }
$$

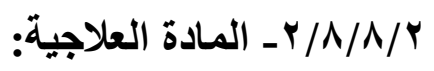

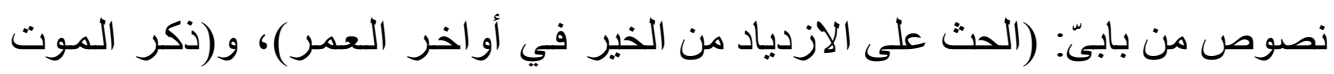

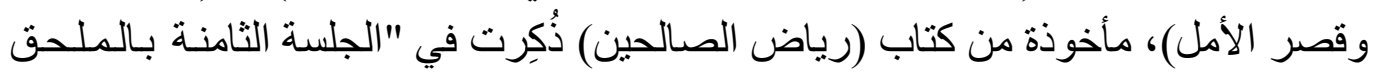

$$
\text { الثاني للدر اسة". }
$$

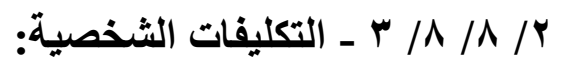

أـ لا تيأس أبدًا، وتيقن من أن الله سيخفر للك على ما فعلت من الصالحات.

بـ قل لنفسك: لا يز ال أمامي عمر، سأستغله حتى آخره في فعل الصالحات التي تُرضي

$$
\text { الله عني. }
$$

- وقت نهاية الجلسة: الساعة • ب. • ( مساءً ـ مدة الجلسة: . ـ د دقيقة.

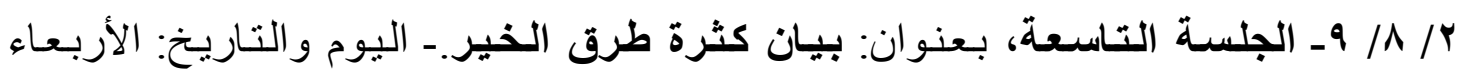

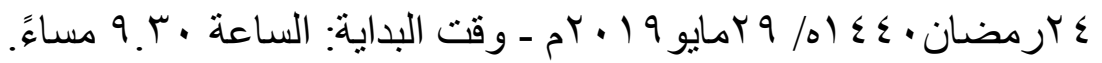

$$
\text { - } 1 / 9 / \Lambda / r
$$

هدفت الجلسة السابقة إلى عدم اليأس من اقتر اب الأجل، وحث المسن على الازديـاد من أند

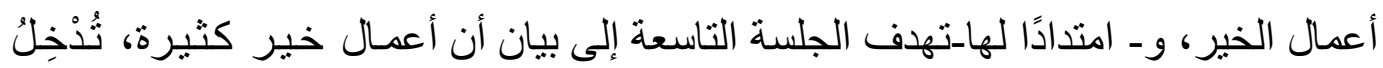

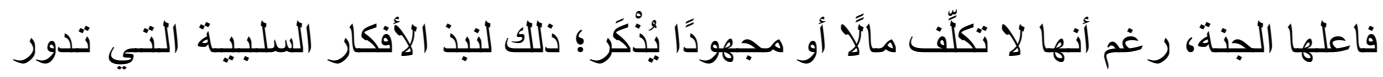

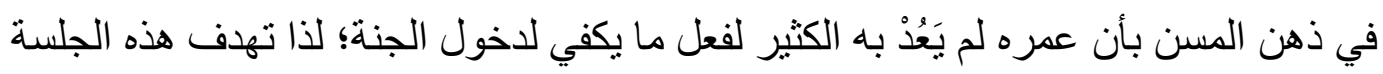




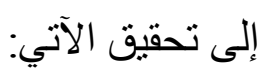

أـ تشجيع المسن على فعل ما يستطيع من الخير ات، و لا يحقرن منها شيئًا.

بـ تذكير المسن بأن مَن يعمل مثقال ذرةٍ خيرًا يره.

ج- تحفيز المسن لدو ام فعل الأعمال التي ثُدْخِل صاحبها الجنة، كما جاءت في في آيـات الله

$$
\text { و أحاديث رسوله }
$$

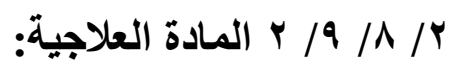

نصوص من: (باب بيان كثرة طرق الخير) مأخوذة من كتاب (ريـاض الصـالحين)،

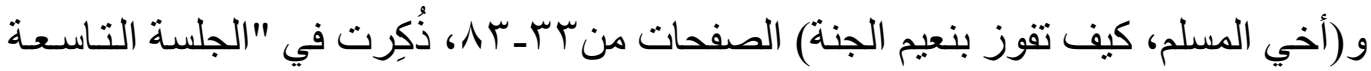

$$
\text { بالملحق الثاني للار اسة" }
$$

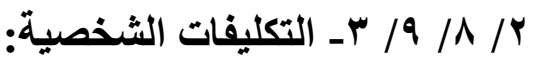

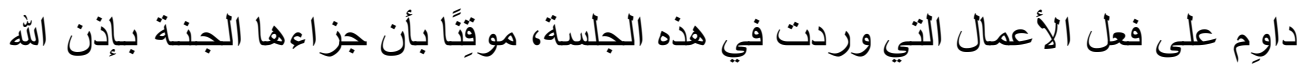

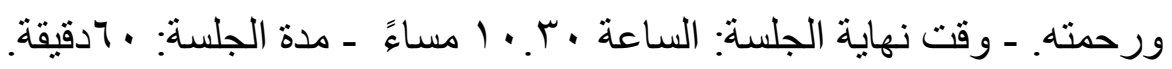

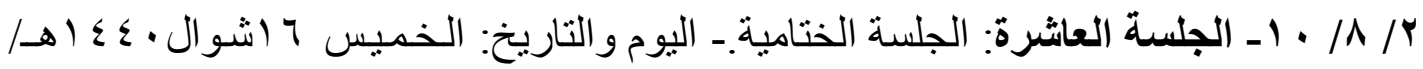

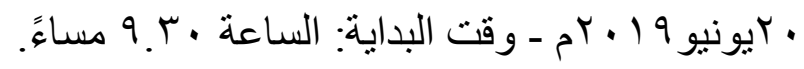

$$
\text { (أهداف }
$$

تهذف هذه الجلسة إلى شكر أفر اد المجمو عة العلاجية على: حضور البرنامج العلاجي، وثقتهم في الباحث، وطريقة العـلاج بـالقراءة، وإصـرارهم

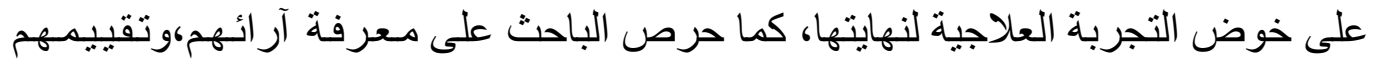

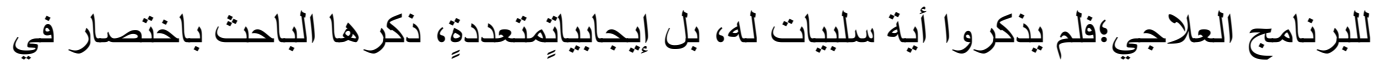
الجلسة العاشرة من الملحق الثاني للار اسة. ثم انتقلت الجلسة للهدف الرئيس لها، وهو قياس فاعلية البرنامج القرائي المستخدم في علاج

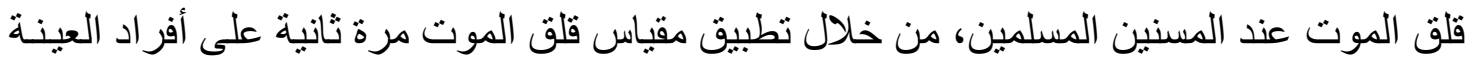

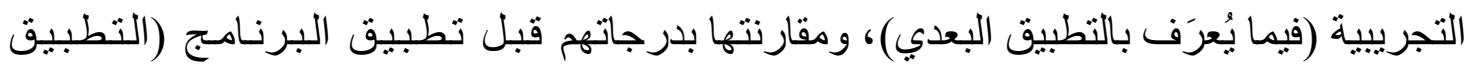

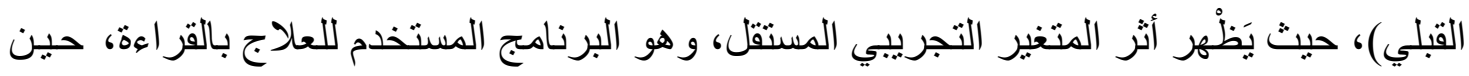
يوجد فروق بين التطبيقين لصالح التطبيق البعدي.

\section{ثالثًا التقيميم وعرض النتائج}

أسفر تطبيق التجربة العلاجية لقلق الموت عند المسنين المسلمين بـاستخدام برنـامج القراءة

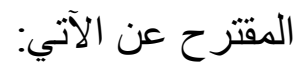




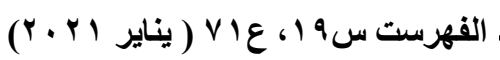
علاج قلق الموت بالقراعة: دراسة تجريبية على عينة من المسنين

r/ 1 - انخفاض درجات قلق الموت: حيث انخفضت درجات قلث الموت لكل أفراد العينة التجريبية في التطبيق البعدي عنه في القبلي، وهو ما يتضح في الجدول و الثكل الآتيين؛ ما يدل

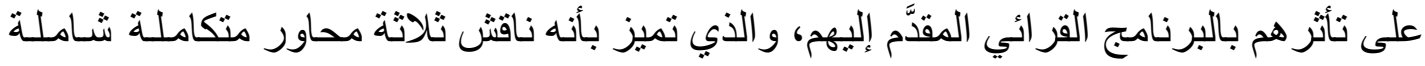

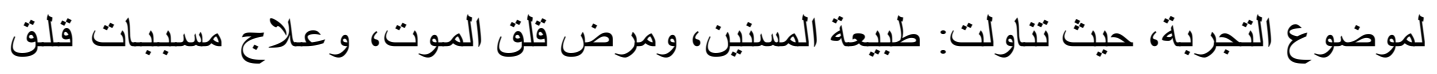
الموت.

جدول(0): درجات المسنين في التطبيقيْن القبلي و البعدي لقلق الموت.

\begin{tabular}{|c|c|c|c|c|c|c|c|c|}
\hline البعدي & القبالي & مسن & البعدياس & القبلي & مسن & البعدي & القبلي & مسن \\
\hline$\leqslant 9$ & 71 & מן & OY & $\lambda T$ & م11 & 01 & $\nabla r$ & ק \\
\hline$\leqslant 0$ & 7. & $r_{p}$ & 0 . & $V Y$ & $1 T_{p}$ & 0 . & Vo & $r_{5}$ \\
\hline $0 \leqslant$ & $\Lambda T$ & R RTr & 0. & 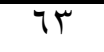 & $1 T_{p}$ & Or & $\overline{v \wedge}$ & $r_{p}$ \\
\hline 0. & $\Lambda$. & $r \leqslant p$ & 0 . & 71 & p p & 0 . & VV & م م \\
\hline$\leqslant \wedge$ & Vo & $r \theta_{p}$ & $\varepsilon 9$ & $\sqrt{V 7}$ & $10_{0}$ & $\sum 9$ & 79 & م \\
\hline 0. & $V V$ & ק מד & $\leqslant 0$ & 70 & 18 & or & (1) & ק \\
\hline 0\{ & $V T$ & $r V_{p}$ & OY & $7 T$ & $I V_{p}$ & 0. & $V^{\prime}$ & $v_{p}$ \\
\hline or & $\Lambda Y$ & $r \Lambda^{\beta}$ & $\varepsilon V$ & 77 & $1 \Lambda_{5}$ & or & $7 V$ & $\overline{\Lambda_{\rho}}$ \\
\hline 01 & $V$. & rq & 01 & $V \varepsilon$ & 19 p & Or & VI & $a_{p}$ \\
\hline 0\{ & (1) & r. & 0. & $V \varepsilon$ & r. & 01 & 19 & 1.0 \\
\hline
\end{tabular}

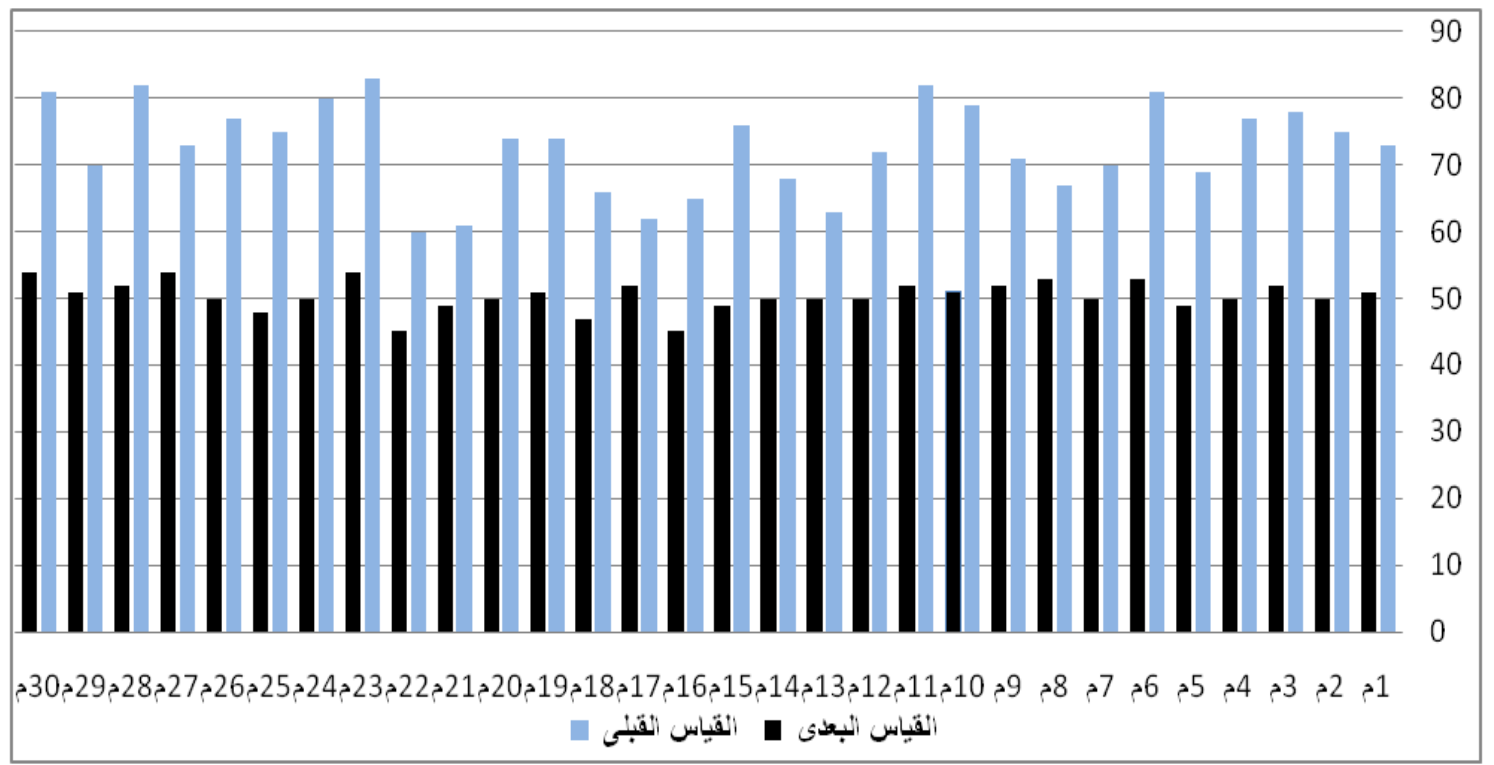

شكل(r): مقارنة درجات أفر اد المجموعة العلاجية في التطبيقين القبلي و البعدي. 


\section{ب/ ץ ـ التحليل الإحصائي لنتائج التجربة}

اعتمدت الدراسة على بعض المعاملات الإحصائية لقياس أثر البرنامج القرائي في علاج قلق

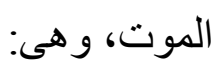

Paired-sample T.test ك/ للفروق بين متوسطات درجات العينة

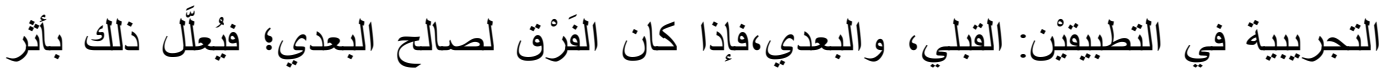
المتغير التجريبي المستقل، وهو البرنامج القرائي المستخدم(ب0).

\begin{tabular}{|c|c|c|c|c|c|c|c|}
\hline دلالة قيمة & قيمة مستّوى المعنوية & قيمة & الحرية & الالاعرافي & الحستوسي & العدد & التطبيق \\
\hline \multirow{2}{*}{ مستوى د. } & \multirow{2}{*}{$\because \cdots$} & \multirow{2}{*}{15.00} & \multirow{2}{*}{$r q$} & $q . \Gamma \leq$ & v1. 9 & $r$. & قبلي \\
\hline & & & & $\overline{r . T V}$ & $0 . . \leq 7$ & $r$. & بعدي \\
\hline
\end{tabular}

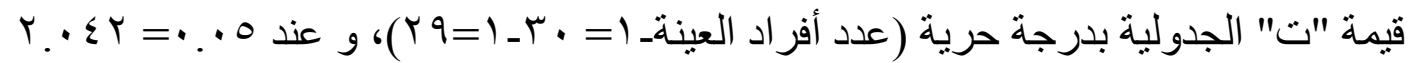

جدول(T): نتائج اختبار تِ للفروق بين متوسطات درجات المجموعة العلاجية في التطبيقيْن.

$$
\text { القبلي و البعدي. }
$$

يتضح من نتائج الجدول السابق ثبوت فاعلية البرنامج القرائي في خفض مستوى قلق الموت،

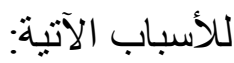

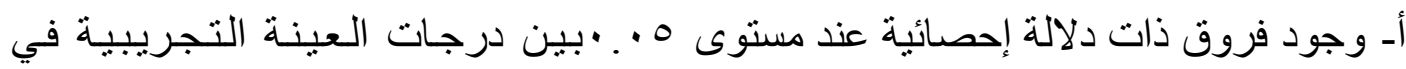

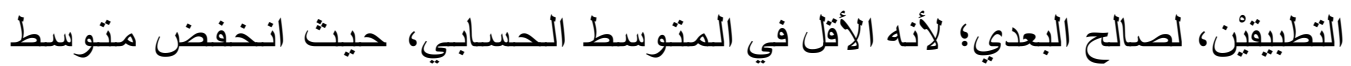

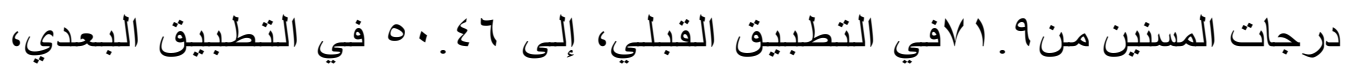

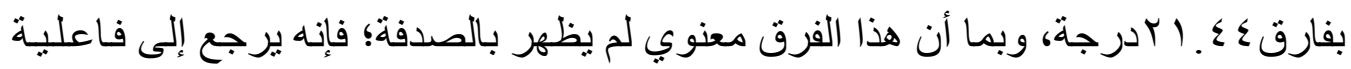

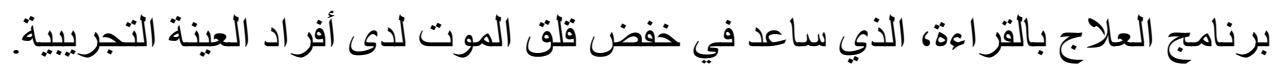

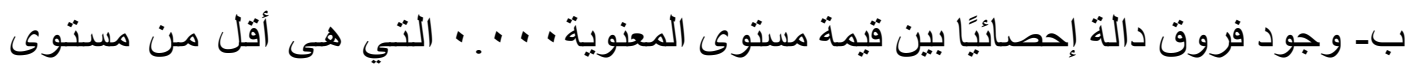

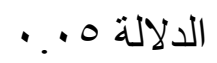

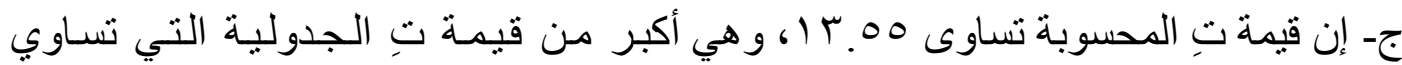

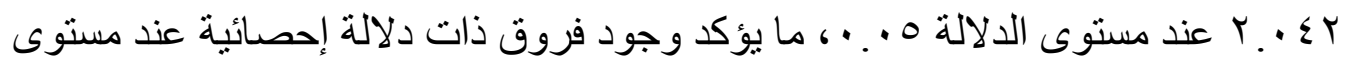

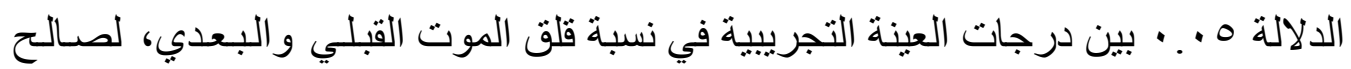

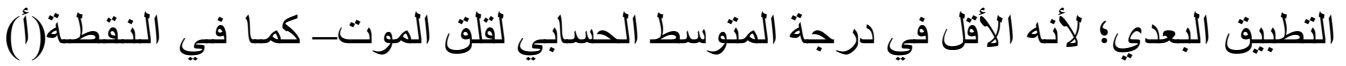
السابقة. 
دـ وجود فروق ذات دلالـة إحصـائيـة بين قيمـة الانحر اف المعيـاري لصـالح التطبيق

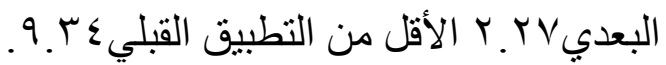

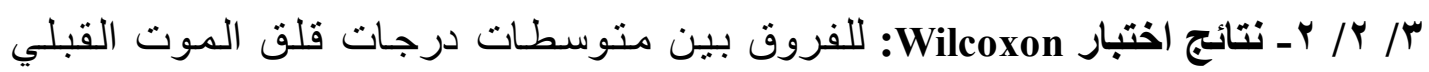
و البعدي.

\begin{tabular}{|c|c|c|c|c|c|c|c|c|}
\hline \multirow[b]{2}{*}{ الدلالة } & \multirow{2}{*}{ مستثوى } & \multirow[b]{2}{*}{ إختبار Z إحساء } & \multicolumn{2}{|c|}{ متوسط الرتب } & \multirow[b]{2}{*}{ الانحر افياري } & \multirow{2}{*}{ الحستبي } & \multirow[b]{2}{*}{ العدد } & \multirow[b]{2}{*}{ التطبيق } \\
\hline & & & $\begin{array}{c}\text { الإشارة } \\
\text { (+) }\end{array}$ & $\begin{array}{c}\text { الإشارة } \\
\text { (-) }\end{array}$ & & & & \\
\hline \multirow{2}{*}{$\because 0$} & \multirow{2}{*}{$\because \cdots$} & \multirow{2}{*}{$\varepsilon . \vee 10$} & \multirow{2}{*}{ r.o. } & \multirow{2}{*}{10.91} & $9 . r \varepsilon$ & V). 9 & $r$. & قبلي \\
\hline & & & & & T.YV & 0.57 & $r$. & بعدي \\
\hline
\end{tabular}

جدول(V): نتائج اختبار Wilcoxon للفروق بين متوسطات درجات قلق الموت القبلي و البعدي.

يتضح من الجدول السابق ثبوت فاعلية البرنامج القرائي في خفض مستوى قلق الموت،

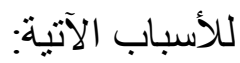

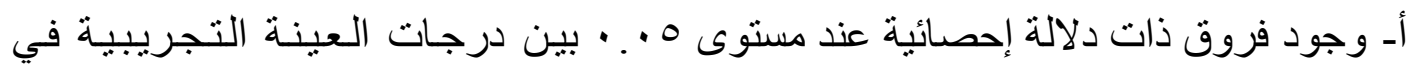

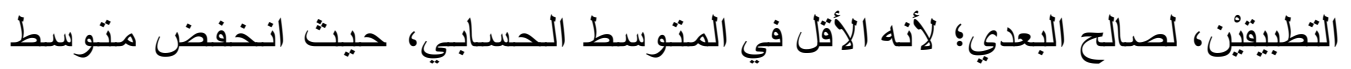

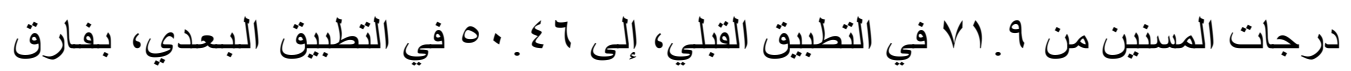

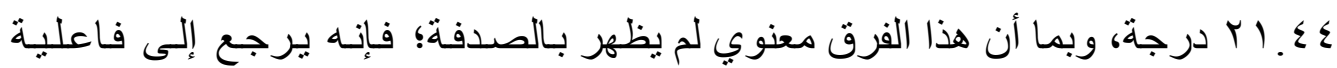

برنامج العلاج بالقر اءة، الذي ساعد في خفض قلق الموت لدى أفر اد العينة التجريبية.

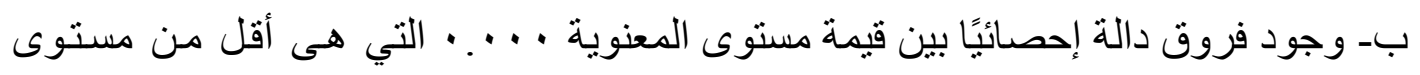

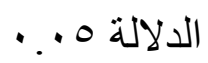

ج- وجود فروق دالة إحصائيًا بين قيمة الانحر اف المعياري لصالح التطبيق البعدي VV. T.

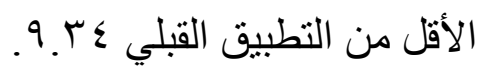

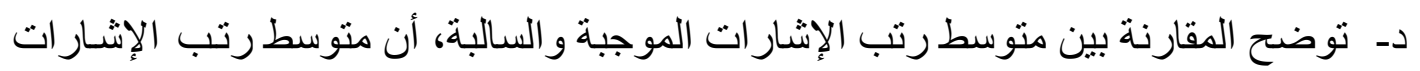

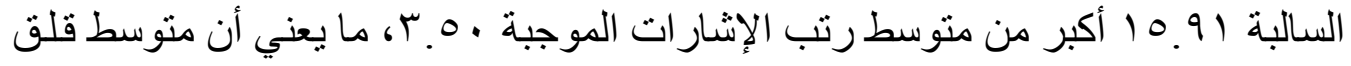

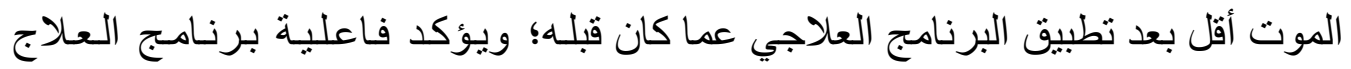
بالقر اعة في تخفيف حدة قلق الموت لدى العينة التجريبية، وهو ما يمكن تطبيقه على أفرادٍ آخرين.

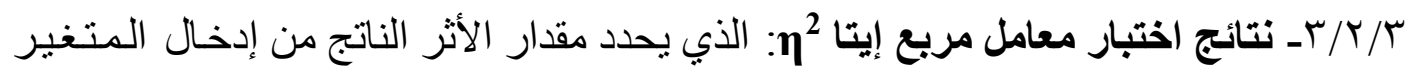

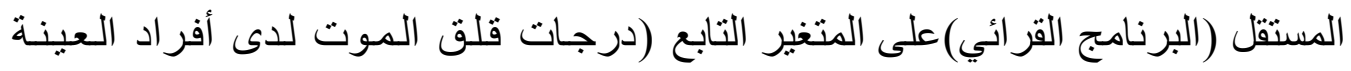


التجرييية)، وقوة الارتباط بين المتغيريْن، و استعان الباحث ببرنامج إكسل Excell لحسـاب

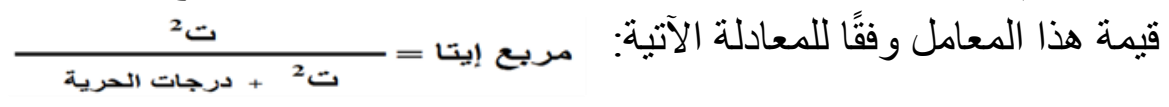

\begin{tabular}{|c|c|c|c|c|}
\hline قيمة مربع لإيتا(Y Y ) & قيمة ( ت ) & المتوسط الحسابي & العدد & التطبيق \\
\hline \multirow[t]{2}{*}{.$\wedge V$} & \multirow[t]{2}{*}{$1 \pi .00$} & $v 1.9$ & $r$. & القبلي \\
\hline & & $0 . . \leqslant 7$ & $r$. & البعدي \\
\hline
\end{tabular}

جدول (^) قيمة مربع إيتا لأثر البرنامج القرائي في علاج قلق الموت عند المسنين المسلمين.

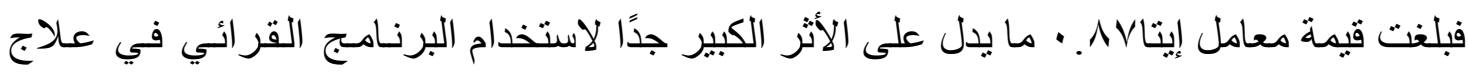

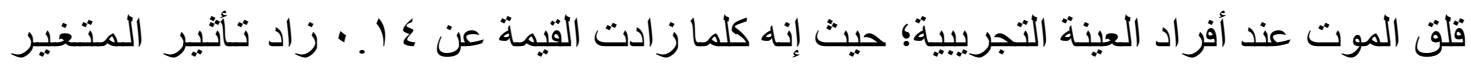
المستقل على المتغير التابع (َ؟r) r/ ץ/ عـ نتائج اختبار معامل كوهين لقياس أثر المتغير المستقل في المتغير التابع في العينات

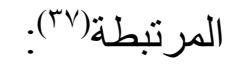

\begin{tabular}{|c|c|c|c|c|c|c|}
\hline كوهين & قيمة تِ & 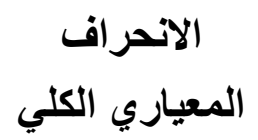 & الانحر افياري & الحستوسط & عدد أفراد & المجموعة \\
\hline \multirow{2}{*}{$Y . \Sigma V$} & \multirow{2}{*}{11.00} & \multirow{2}{*}{1.77} & $9 . \mu \varepsilon$ & 11.9 & r. & قبلي \\
\hline & & & T.YV & $0 . . \leqslant 7$ & $\Gamma$. & بعدي \\
\hline
\end{tabular}

جدول (9) قيمة معامل كوهين لأثر البرنامج القرائي في علاج قلق الموت عند المسنين المسلمين.

$$
\begin{aligned}
& \text { يُمكن حساب قيمة معامل كو هين باستخدام معادلة (معامل كو هين = }
\end{aligned}
$$

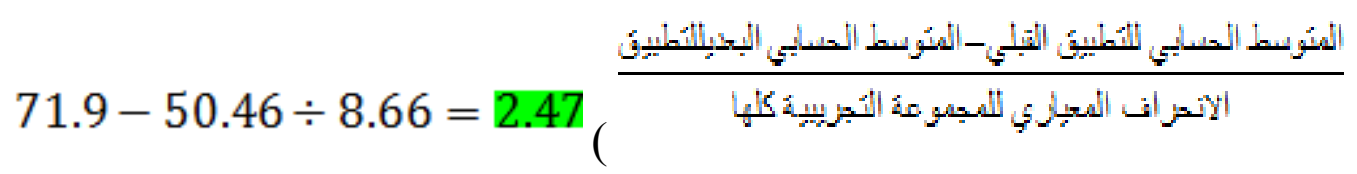

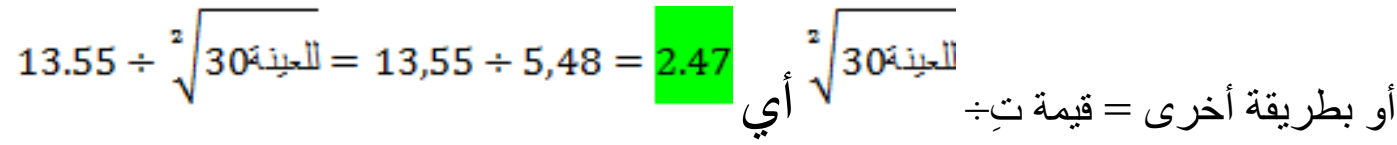

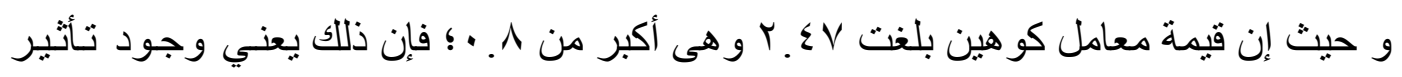


هذا ويُرجِع الباحثُ نتائجَ المعاملات الإحصائية السابقةـ التي أكدت جميعها فاعلية البرنـامج

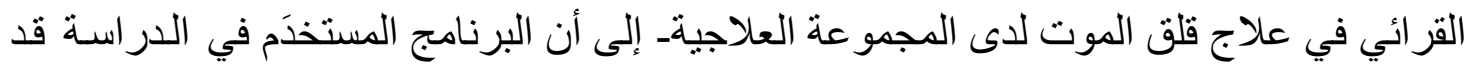

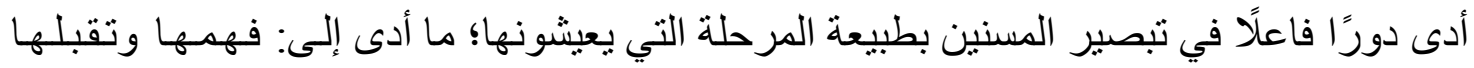

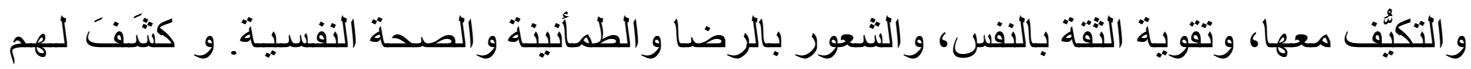

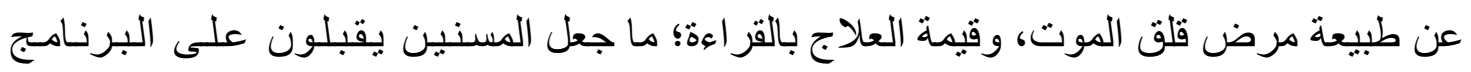

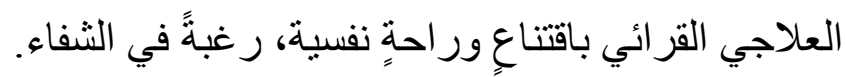

وساعد البرنامج في اكتساب اتجاهات جديدة نحو الموت-و ما يتعلق به من موضو عات-من

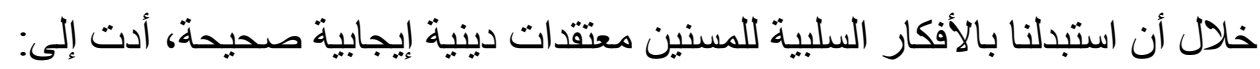
أـ تبصير ومساندة المسن للثفاء من قلق الموت، عن طريق الثعور بالطمأنينة و الثقة في رحمـة الله التي بدركها. ب: التوبة النصوح، التقرب إلى الله بالطاعات و الأعمال الصالحة عظيمة الأجر ، و عدم القنوط من

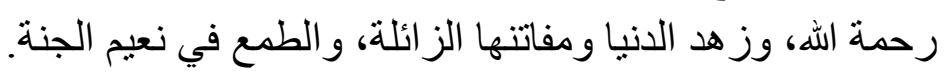
و عمدت التجربة العلاجية إلى اقتباس كل المعتقدات الإيجابية عن الموت من تعـاليم القرآن الكريم والسنة النبوية، مَصْدَرَىن الدين الإسلامي؛ فز اد تصديق ويقين المسن بهـا. وتتفق هذه

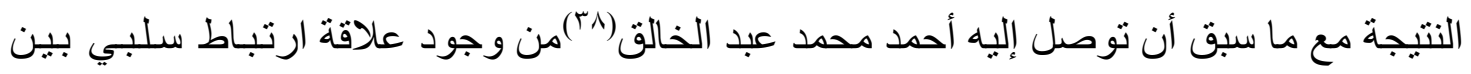

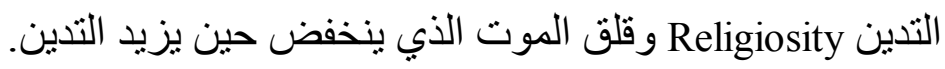

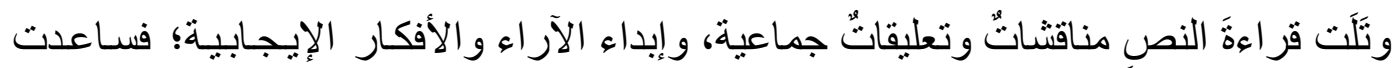

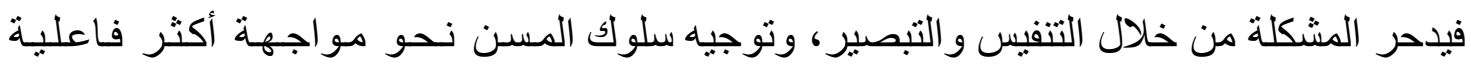

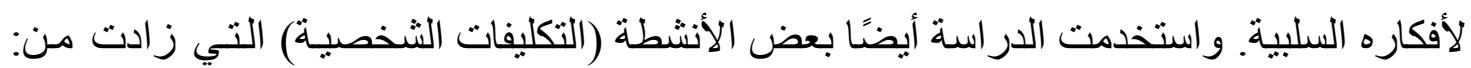

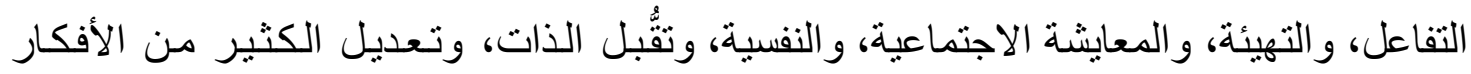
والاتجاهات السلبية نحو الموت، وتعديل السلوك، وتعميق الإيمان الروحي لدى المسنين. وبذلك تشير نتائج الدر اسة الحالية إلى إمكانية استخدام العلاج بالقر اءة وحده بديلً عن طرق العلاج الأخرى- وليس مساندًا لها- في خفض قلق الموت عند المسنين؛ لأنه يسـاعد في تعزيز

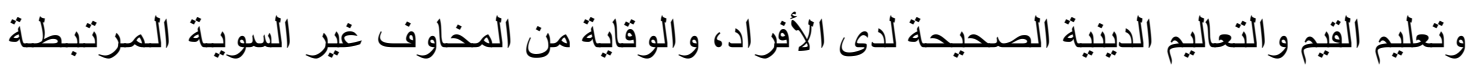

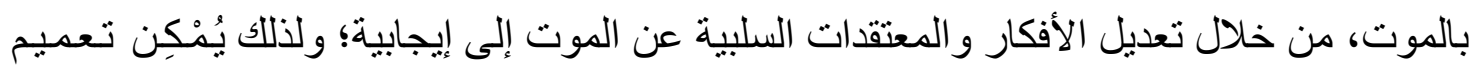

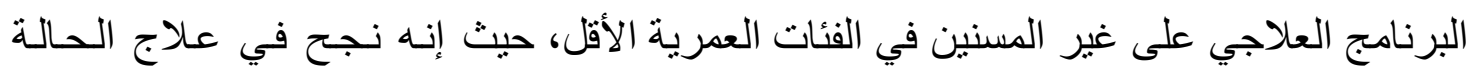
الأصعب- المسنين- والأكثر تأثرًا بقلق الموت، ويرى الباحث أنه سينجح في علاج غير المسنين

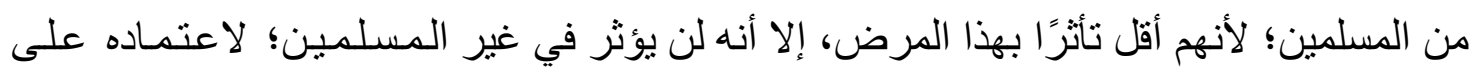
الآيات القر انية و الأحاديث النبوية، التي قد لا تصادف تأثثرًا عقائديًا في غير فئر المسلمين. 


\section{ب/r ـ الوقت اللازم لعلاج قلق الموت ببرنامج القراعة}

استغرق علاج قلق الموت بالبرنامج المقترح ، ؟0 دقيقة، أي ما يعادل تسع سـاعات، وهى

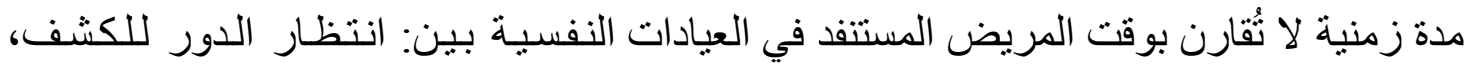

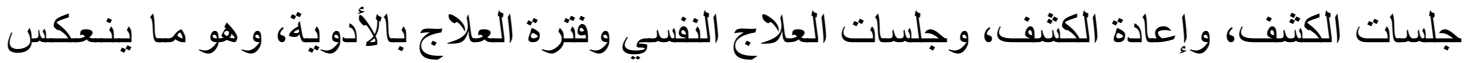
على التكلفة و المجهود النازم لذلك.



\begin{tabular}{|c|c|c|c|c|c|}
\hline \multicolumn{3}{|c|}{ تكلفة العلاج النفسي } & \multicolumn{3}{|c|}{ تكلقة برنامج العلاج بالقز اءة } \\
\hline بداية السعر & المكونات & $\bar{b}$ & السعر & المكونات & $\bar{b}$ \\
\hline 10 & كثف الطبيب & 1 & \multirow{2}{*}{ مجانًا على الويب } & \multirow[b]{2}{*}{ قلق الموت } & \multirow[b]{2}{*}{1} \\
\hline$\leqslant 0$. & جلسات العلاج & $r$ & & & \\
\hline$r \cdot$ & المهئًات & $r$ & \multirow{2}{*}{$\varepsilon$. } & \multirow{2}{*}{ 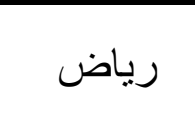 } & \multirow{2}{*}{ r } \\
\hline 7 & المنومات & $\varepsilon$ & & & \\
\hline$\varepsilon$. & مهئات الجهاز & 0 & \multirow[t]{2}{*}{7.} & \multirow{2}{*}{ كيف تفوز المسلم } & \multirow[t]{2}{*}{ r } \\
\hline$\wedge$. & إعادة الكثنف & 7 & & & \\
\hline \multicolumn{3}{|c|}{$V \leqslant 7$} & \multicolumn{2}{|c|}{$1 \cdots$} & الجملة \\
\hline
\end{tabular}

جدول (• ( ) تكلفة علاج قلق الموت بالقر اءة مقارنةً بالعلاج النفسي و الأدوية.

بلغت تكلفة البرنامج القرائي لعلاج قلق الموت . . ا جنيه مصري، هى مجموع أسعار كتب

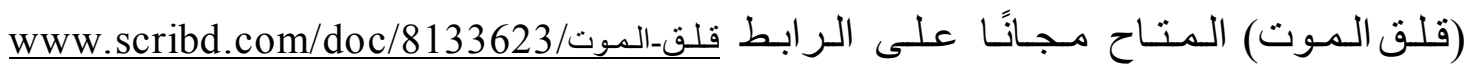

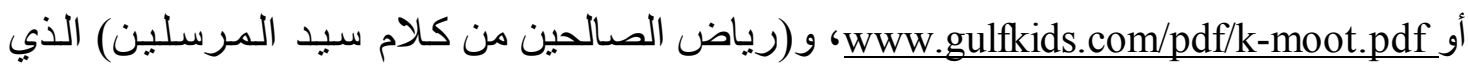
ييلغ سعره • ع جنيهًا، و أيضًا متاح مجانًا على الر ابط

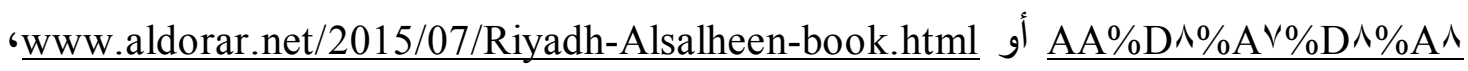

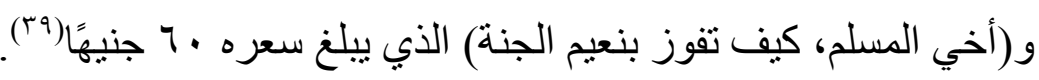

أما تكلفة العلاج النفسي الذي يبدأ بالعرض على الطبيب النفسي (أســار الكشف تبدأ

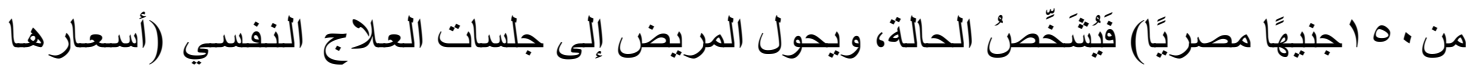

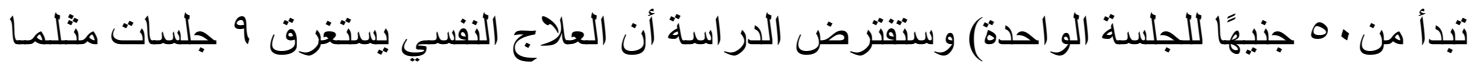

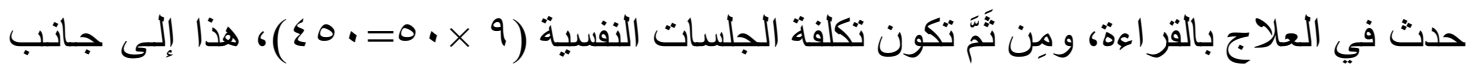


العلاج المساعد بالأدوية الذي لا يقل عن نوع و احد من: المهدئات (أسعار ها تبدأ من • ب جنيـهًا)،

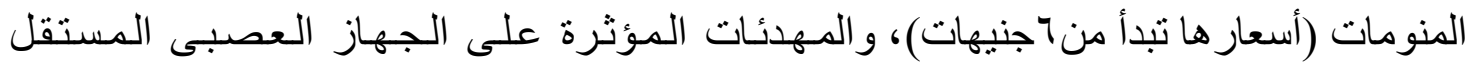

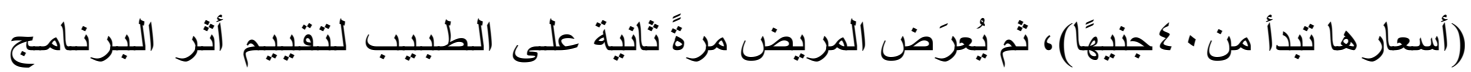

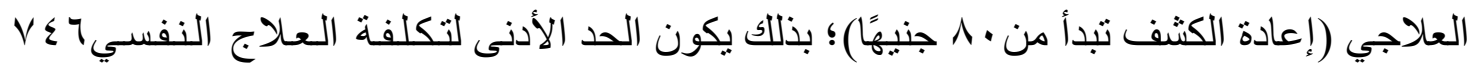

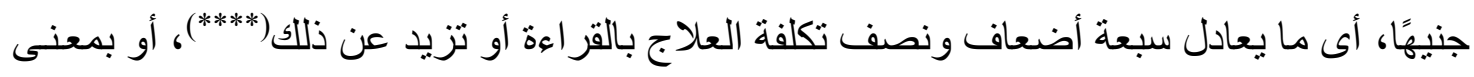

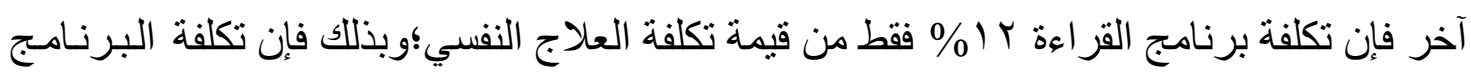

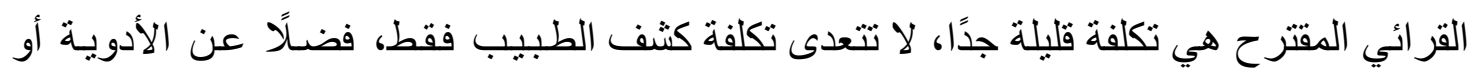
جلسات العلاج النفسي.

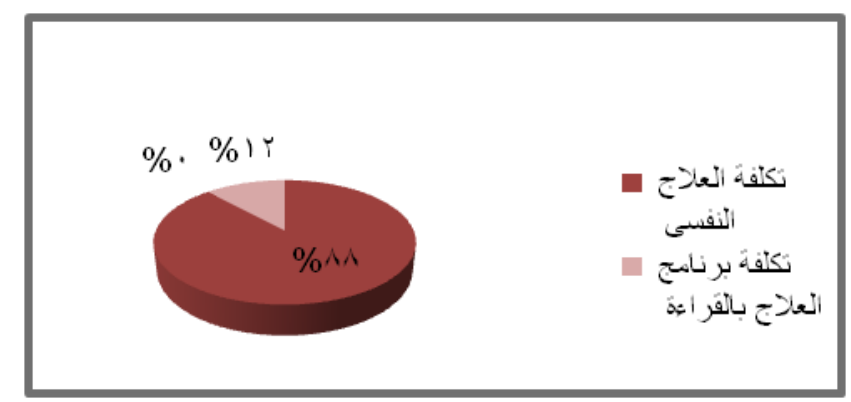

شكل(r): نسبة تكلفة برنامج العلاج بالقر اعة إلى تكلفة العلاج النفسي.

و إذا قِسنا ذلك بمبدأ عائد التكلفة؛ نجد أن عائد البرنامج القرائي كبير، ظَهَرَ في أثنره الفعـال القوي دون أن يكون له آثار جانبية، فضلً عن مميز اته التي سبقت الإشارة إليها عند ثقيهيم نتائسج التجربة العلاجية، في حين أن الطر ائق الأخرى لعلاج قلق الموت أكثر تكلفة، وتتعدد عيوبها، وقد أوضحت الدر اسة ذللك عند عرض طر ائق علاج قلق الموت. 


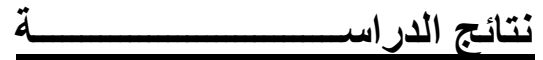

أسفرت الدر اسة عن الوصول إلى النتائج الآتية:

أـ وجود فروق ذات دلالة إحصائية عند مستوىه •. · بين درجات العينة التجريبية في التطبيقبن:

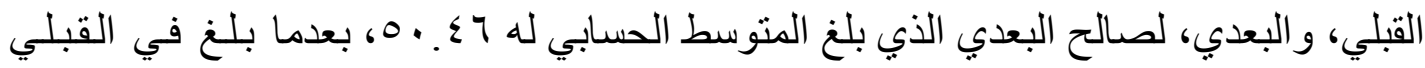

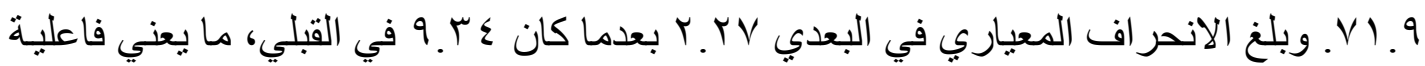
البرنامج القرائي المقترح في خفض مستوى قلق الموت لدى أفر اد المجمو عة العلاجية.

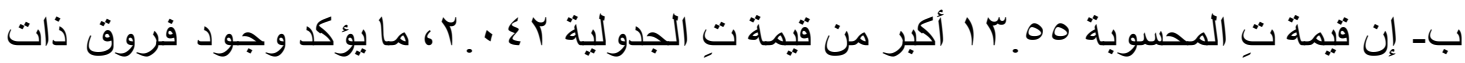

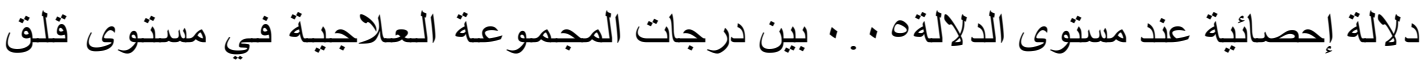

$$
\text { الموت القبلي و البعدي، لصالح التطبيق البعدي. }
$$

ج- انخفض منوسط رثب الإشار ات الموجبة في اختبار Wilcoxon ليبلغ •م. ب، بعدما كان

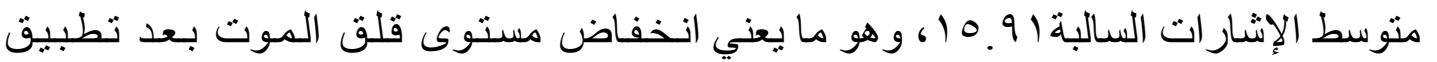

$$
\text { البرنامج العلاجي عما كان قبله. }
$$

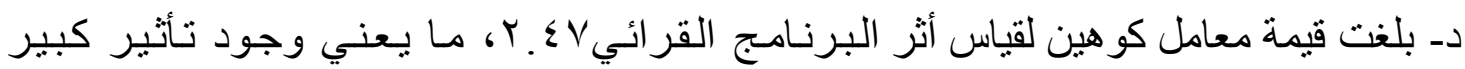

$$
\text { للبرنامج. }
$$

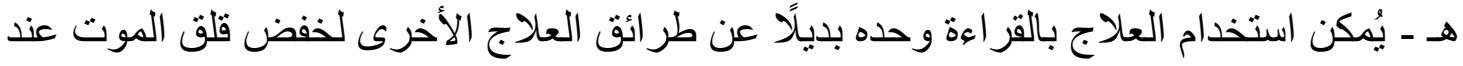
المسنين و غير هم من الفئات الأخرى. و - يستغرق علاج قلق الموت ببرنامهج القراءة المقاء المقترح

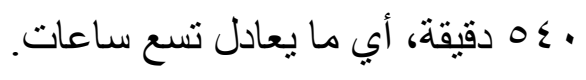

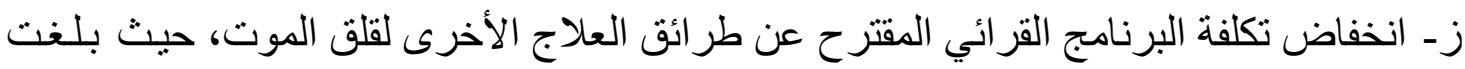

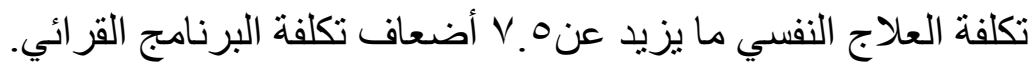
ح- لم يجد الباحث إنتاجًا فكريًا عربيًا أو أجنبيًا مخصصًا بالكامل لعلاج قلق الموت. 


\section{التوصيات}

تطرح الدراسة بعض التوصيات للأطراف الفاعلة المهتمة بمجالات: الصحة النفسية، و المسنين، وبالقر اءة؛ أملًا في الارتقاء بهذه المجالات، وتشمل:

ا ـ صياغة بر امج قراعة علاجية لمختلف الأمر اض النفسية و العضوية التي يُعانى منها كل فئات

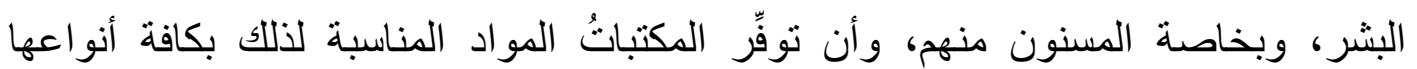
و أشكالها.

r- تصميم بر امج تثقيفية وتأهيلية تُمَكِّن أسر المسنين من رعايتهم ومساندتهم اجتماعيًا وصحيًا و اقتصاديًا ونفسيًا. r- إنشاء قاعدة بيانات لكبار السن، وما يتعلق بكل منهم من مشكلات، و احتياجات، و الدعم

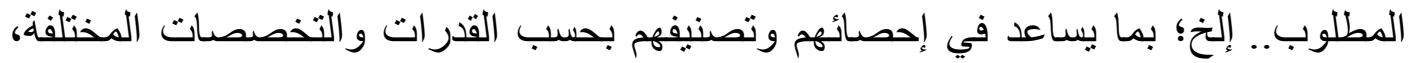
و الاحتياج إلى الرعاية، سواء أكانت الصحية أم الإيوائية أم الاقتصادية... إلخ، ويساهم في لئي

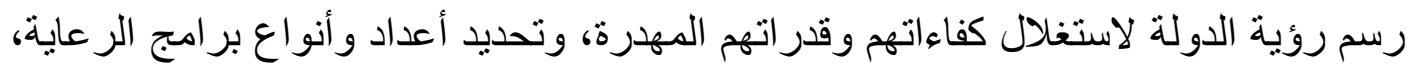
وتحديد المؤسسات اللازمة لذلك سواء أكانت رسمية أم غير رسمية.

عـ الاهتمام بأندية ودور رعاية المسنين، وتوفير كافة متطلبات الحياة الكريمة للمسنين فيها، وبخاصة الأطباء في مختلف التخصصات، لا سيما النفسيين لمساعدة المسن على فهم وتقدير

$$
\text { ذاته، ودحر المشكلات النفسية. }
$$

هـ يجب أن تُكَِّن المؤسساتُ التعليمية والإعلامية قيمًا و اتجاهات إيجابية نحو المسنين عند أفر اد

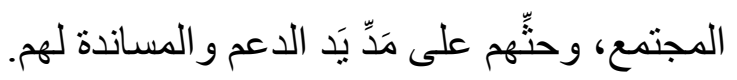

7- يجب أن يدرك كل فرد أن رحمة الله واسعة، وباب التوبة مفتوح لله ما لم يغر غر، وأن الله يغفر

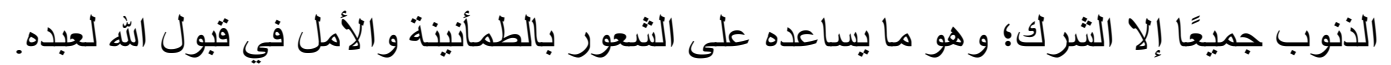
V- تنشئة وتشجيع النشء على القراءة، لتصبح عادة ووسيلة بتغلب بها الفرد طوال حياته على التى التهي الأخلاقيات الثاذة والمشكلات والانفعالات والأفكار السلبية...إلخ، بما بيؤدي إلى بلى تكوين

شخصية سوية نافعة للمجتمع.

^ـ إجر اء مزيد من الدراسات العلمية لعلاج قلق الموت بالقراعة عند فئات أخرى من المسلمين

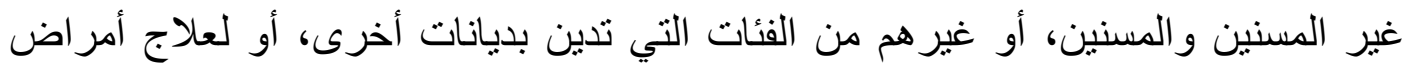
أخرى عند مختلف فئات البشر. 9 ـ تشجيع المؤلفين و المترجمين و الناشرين على إنتاج مواد المعلومات التي يمكن الاعتماد عليها في علاج مختلف المشكلات و الأمر اض التي تصيب الإنسان، سو اء أكانت نفسية أم اجتماعية 


$$
\text { أم عضوية ... إلخ. }
$$

• ا ـ إدر اج مقرَّر (العلاج بالقر اءة) في كل أقسام المكتبات و المعلومات؛ لتخريج مكتبيين مؤهَّلين

للتعامل مع مختلف الحالات المرضية، وتقديم خدمة العلاج بالقر اعة للأفر اد أينما وُجِدوا.

\section{المصادر:}

1- Ardelt, M. (2002). Wisdom and religiosity in life and attitudes towards death. Paper presented at international conference on searching for meaning in the new Millennium Vancouver, p. 166.

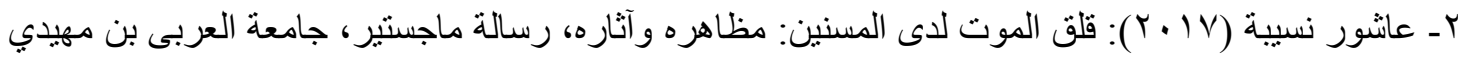

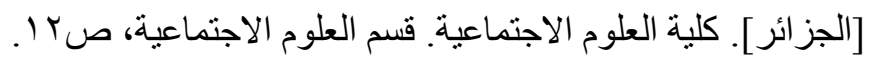

3- Dennison, Carol (2005). The relationship between social support and wellbeing among the elderly. Long Beach: California state university, p. 11.

ع - شعبان خليفة (1991): قاموس البنهاوي الموسوعي في مصطلحات المكتبات والمعلومات، ط تذكارية.

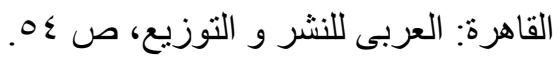

هـ غادة عزت محمود أبو زويد (10 (Y)): علاج الاكتئاب بالقر اءة: دراسة تجرييية على عينة من طلاب كلية

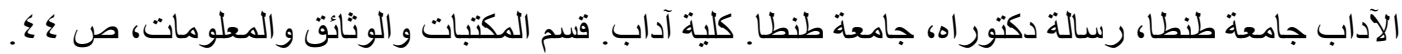

6- Yuan, Shuai[ et. Al] (2018). Comparative efficacy and acceptability of bibliotherapy for depression and anxiety disorders in children and adolescents: a meta-analysis of randomized clinical trial. Neuropsychiatric disease and treatment. vol. 14, p. 354.

7- Tanrikulu, Ibrahim (2011). Self-help books and bibliotherapy: reflections for Turkey. Procedia-social and behavioral sciences. vol. 30, p. 1863.

ᄉـ الجهاز المركزى للتعبئة العامة والإحصاء (10 (10): مصر في أرقام: التقرير السنوى الدورى، القاهرة:

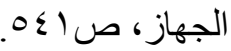

9ـ محمد فتحي عبد الهادي (r . . Y): البحث ومناهجه في علم المكتبات والمعلومات، القاهرة: الدار المصرية

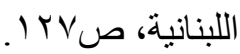

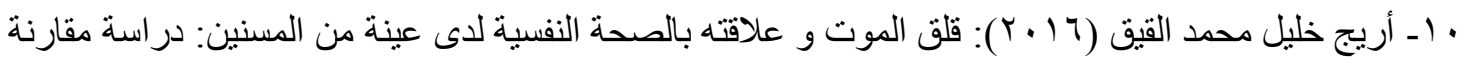

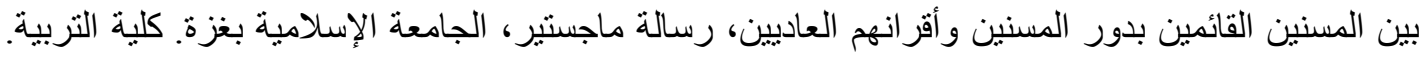
قسم الصحة النفسية و المجتمعية، الصفحات:

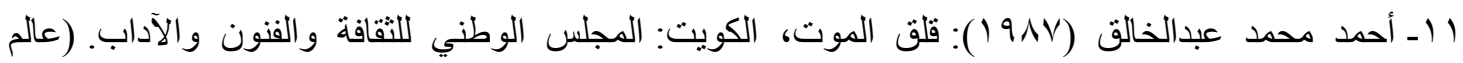

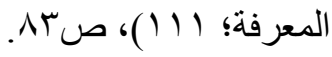


12-Jong, Jonathan [et. al] (Mar.2017). The religious correlates of death anxiety: a systematic review and meta-analysis. Religion, Brain, and Behavior, p. I . Available through EKB at: http://dx.doi.org/10.1080/2153599x.2016.1238844

13-Peretz, Louise Asher (2005).Social support for older with people. London: University of Montofa, p. 110.

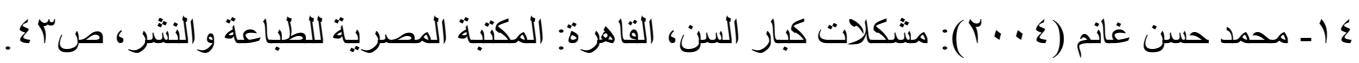

15- Lymbery, Mark (2005). Social work with older people: context policy and practice. $1^{\text {st }}$ published. London: Sage publications Inc., p.63.

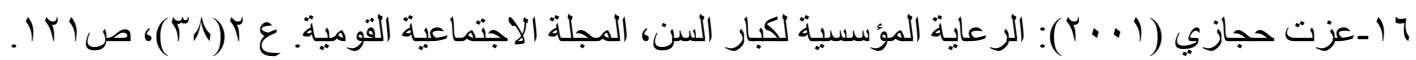

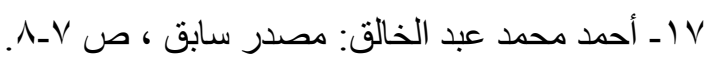

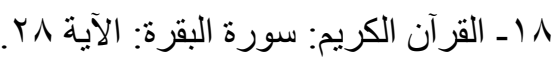

$$
\begin{aligned}
& 9 \text { 1 ا ـ القرآن الكريم: سورة العنكبوت: الآيةله. }
\end{aligned}
$$

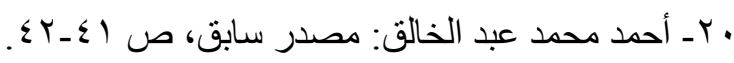

$$
\begin{aligned}
& \text { (Y ـ شيهان، دافيد (99191)): مرض القلق من الموت، ترجمة: عزت شعلاني، القاهرة: عالم المعرفة، صه؟. }
\end{aligned}
$$

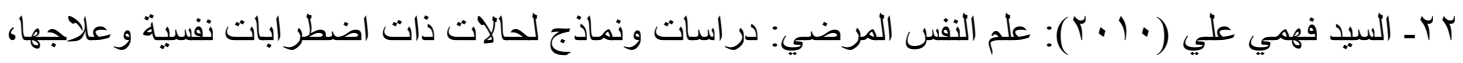

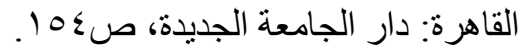

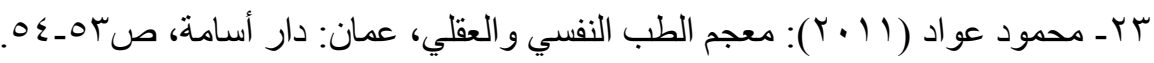

24-Jones, F.A. (Oct.2002). The role of bibliotherapy in health anxiety: an experimental study. British Journal of community nursing. 7(10), p. 498-504. Available through EKB at: http://08105qxpz-1104-y-https-www-scopus-com.mplbci.ekb.eg/sourceid/27158? origin $=$ recordpage

25-Yuan, Shuai [ET.Al] (2018). Op. cit., p. 353.

26-Moses, Harold A. \& Zaccaria, Josef S. (April 1969). Bibliotherapy in an educational context: rational and practices. The High School Journal. 52 (7), pp. 401-411.

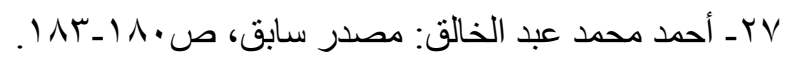

* الأستاذ المتفرغ بقسم علم النفس كلية الآداب جامعة الإسكندرية، و عضو الجمعية النفسية الأمريكية. APA.

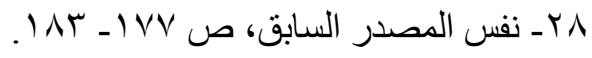

أـ أ.د. مدحت ألطاف عباس، أستاذ الصحة النفسية المتفرغ بكلية التربية جامعة أسوان. 


$$
\text { ب ـ أ.د. خيرى أحمد حسين، أستاذ الصحة النفسية، وكيل كلية التربية جامعة أسوان. }
$$

ج-أ.د. إسماعيل إبر اهيم بدر، أستاذ الصحة النفسية، وكيل كلية التربية ببنها لنشؤون الدراسات العليا و البحوث.

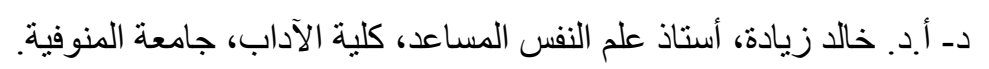

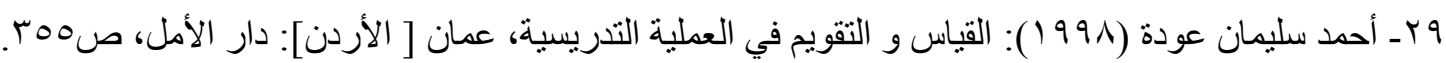

30-Tavakol, Mohsen and Dennick, Reg.(2011). Making sense of Cronbach's alpha.

International Journal of Medical Education.vol. 2, p.54.

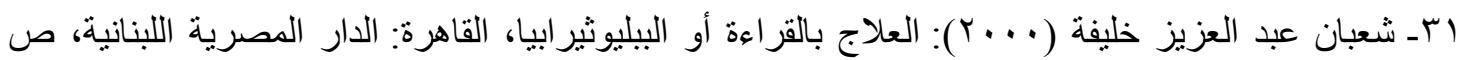
rVq-rVA

$$
\begin{aligned}
& \text { rrـ القرآن الكريم: سورة آل عمران: الآية 111. }
\end{aligned}
$$

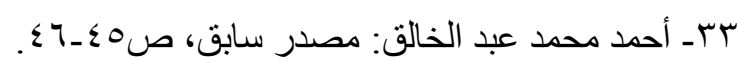

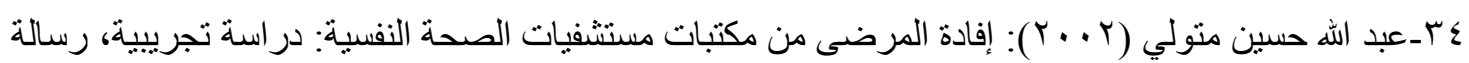

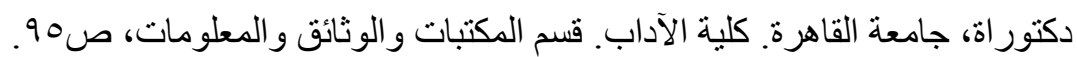

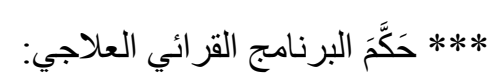

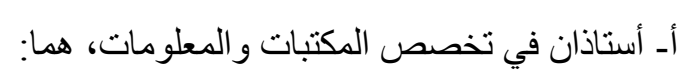

ـ أ.د/حسناء محمود محجوب، أستاذ المكتبات والمعلومات، وكيل كلية الآداب لشؤون التعليم والطلاب، جامعة

المنوفية.

ـ أ.د/ أسامة حامد على، أستاذ المكتبات و المعلومات، وكيل كلية الآداب لثؤون خدمة المجتمع و البيئة، جامعة

$$
\text { بـ أستاذان في تخصصيّ: الفقه الإسلامي، وتفسير القرآن الكريم، هما: }
$$

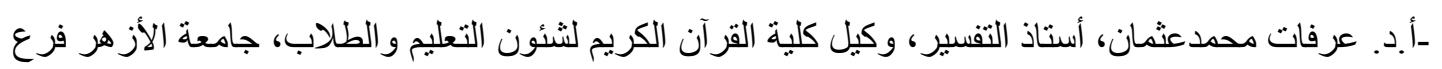

\section{طنطا.}

ـ د. هلال فوزي السباعي، مدرس أصول الفقه، كلية الثريعة والقانون بدمنهور، جامعة الأزهر.

ج- أستاذان في تخصص الصحة النفسية، هما:

ـ أ. د. مدحت ألطاف عباس، أستاذ الصحة النفسية المتفرغ بكلية التربية جامعة أسوان.

ـ أ. د. خيري أحمد حسين، أستاذ الصحة النفسية، وكيل كلية التربية جامعة أسوان.

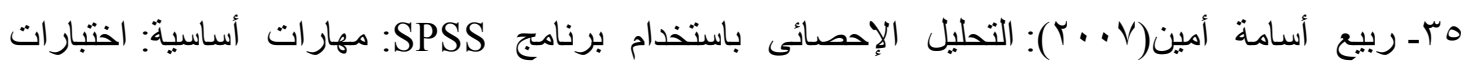

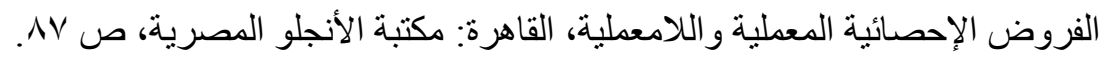

36- Ellis, Paul D. (2010). The essential guide to effect sizes: statistical power, metaanalysis, and the interpretation of research results. New York: Cambridge University Press, p. 41. 


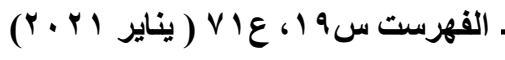
علاج قلث الموت بالقراعة: دراسة تجريبية على عينة من المسنين

37- Ibid., p. 52.

$$
\text { رץ ـ أحمد محمد عبد الخالق: مصدر سابق، ص ؟ } 90
$$

39- www.kanbkam.com/sa/ar/\%D8\%A3\%D8\%AE\%D9\%8A

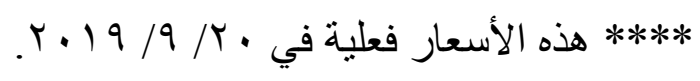

